\title{
Nevada Experiments and Operations Program (N Program) Management Plan
}

\author{
L.A. Nattrass, M.R. Anastasio
}

February 1, 2000

U.S. Department of Energy

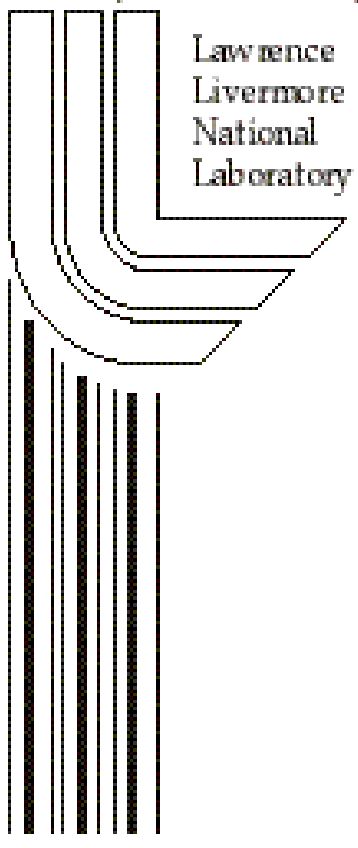




\section{DISCLAIMER}

This document was prepared as an account of work sponsored by an agency of the United States Government. Neither the United States Government nor the University of California nor any of their employees, makes any warranty, express or implied, or assumes any legal liability or responsibility for the accuracy, completeness, or usefulness of any information, apparatus, product, or process disclosed, or represents that its use would not infringe privately owned rights. Reference herein to any specific commercial product, process, or service by trade name, trademark, manufacturer, or otherwise, does not necessarily constitute or imply its endorsement, recommendation, or favoring by the United States Government or the University of California. The views and opinions of authors expressed herein do not necessarily state or reflect those of the United States Government or the University of California, and shall not be used for advertising or product endorsement purposes.

This report has been reproduced directly from the best available copy.

Available to DOE and DOE contractors from the

Office of Scientific and Technical Information

P.O. Box 62, Oak Ridge, TN 37831

Prices available from (423) 576-8401

Available to the public from the National Technical Information Service

U.S. Department of Commerce 5285 Port Royal Rd.,

Springfield, VA 22161 


\section{Nevada Experiments and Operations Program (N Program) Management Plan}

March 2000

Revision 0

[original signed]

[3/13/00]

Lawrence A. Nattrass

Date

Nevada Experiments and Operations Program Leader

Defense and Nuclear Technologies Directorate

Lawrence Livermore National Laboratory 



\section{Contents}

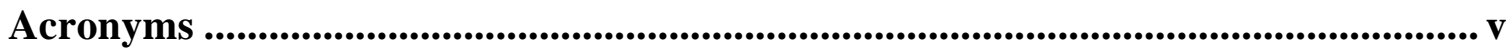

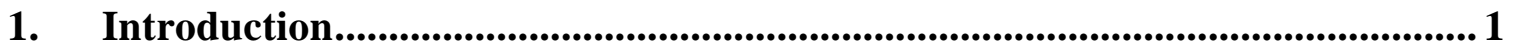

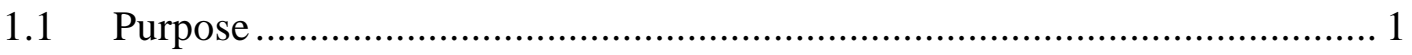

$1.2 \quad$ Scope

2. LLNL Institutional Structure .............................................................................. 2

3. N Program Description ............................................................................................... 3

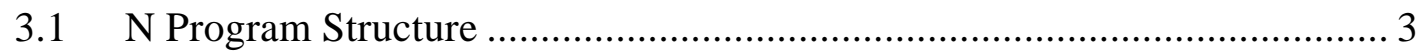

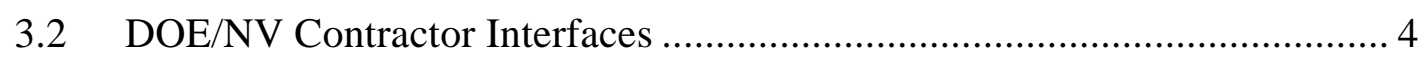

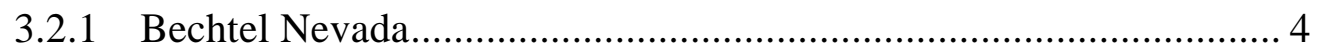

3.2.2 Wackenhut Services, Incorporated .................................................. 4

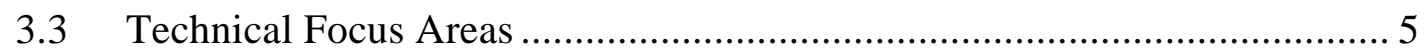

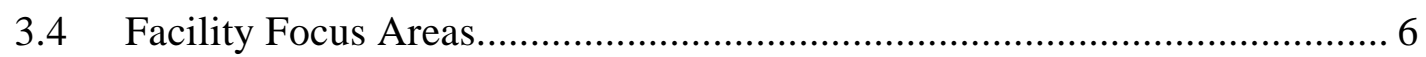

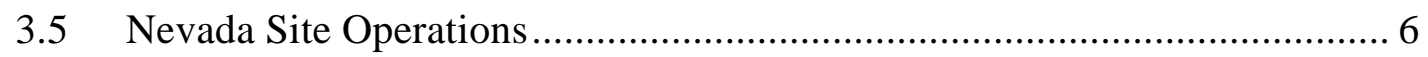

4. Roles and Responsibilities........................................................................................6 6

4.1 Program Leader/Deputy Program Leader ……....................................... 7

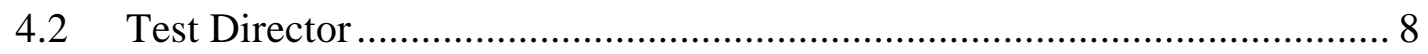

4.3 Nevada Test Organization Resident Manager .......................................... 9

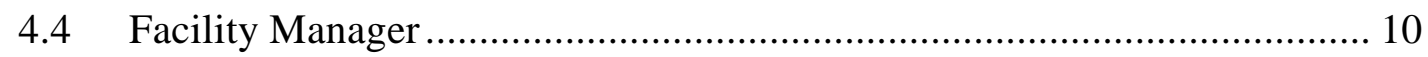

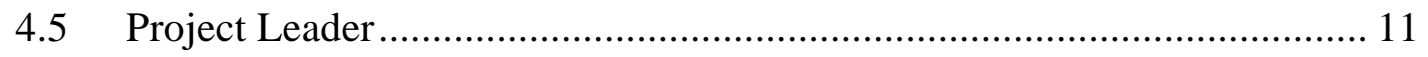

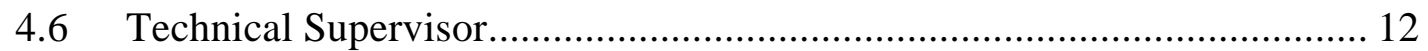

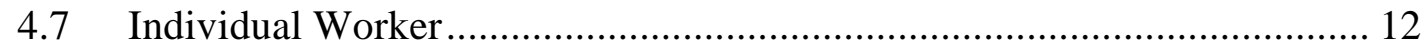

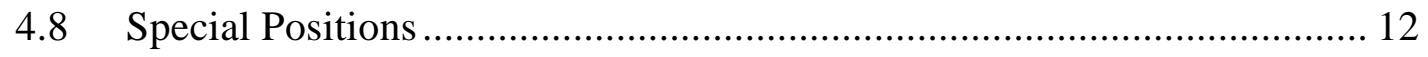

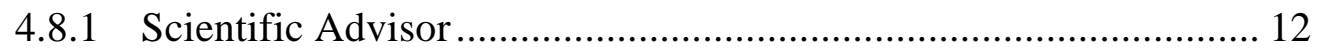

4.8.2 Associate Program Leader ........................................................... 13

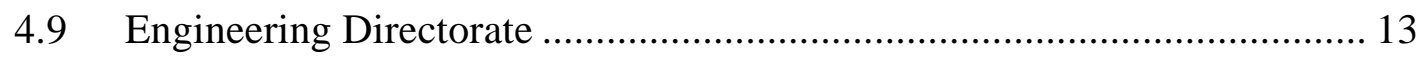

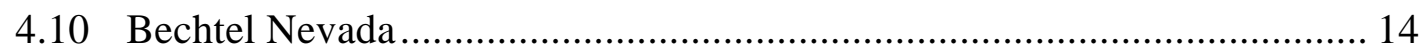

4.11 Wackenhut Services, Incorporated ............................................................ 14

5. Management Elements ............................................................................................. 15

5.1 Integrated Safety Management Requirements....................................... 15

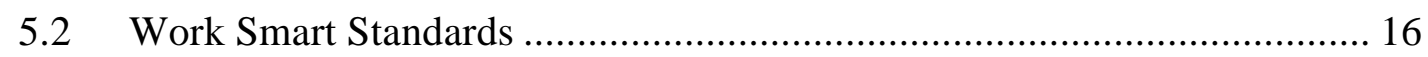

5.2.1 Authorization for Interim Operations ............................................ 17

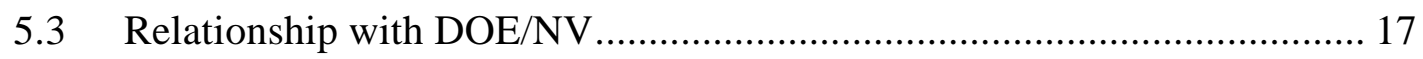

5.3.1 Delegation of Designated Officials ................................................ 17 
5.3.2 Activity Agreements ............................................................. 18

5.3.3 Real Estate/Operations Permits ................................................. 18

5.4 Payroll and Technical Staff Management ............................................... 19

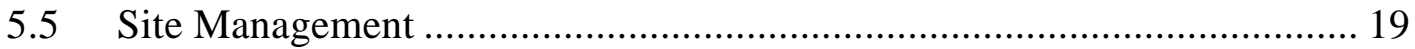

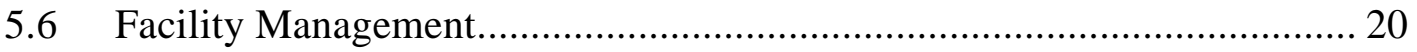

5.6.1 Major LLNL Facilities at NTS ................................................ 20

5.6.2 Other NTS Facilities ................................................................ 21

5.6.3 Facilities Managed by Other Organizations................................ 21

5.7 Representation in Joint Test Organization ............................................ 21

5.8 Funding/ Balanced Priorities ........................................................... 21

$5.8 .1 \quad$ Direct Funding .................................................................... 21

5.8.2 LLNL-Directed DOE/NV Funding ........................................ 22

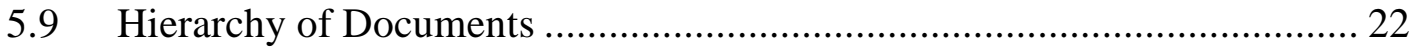

5.10 Work Authorization Process.............................................................. 24

5.10.1 Flowdown of Requirements .................................................. 24

5.10.2 Line Management Responsibility for Safety................................ 24

5.10 .3 Elements of the Authorization Process ........................................ 25

5.10.3.1 Facility Operations .................................................. 25

5.10.3.2 Work Activities ...................................................... 25

5.11 Qualification of Personnel............................................................. 25

5.11.1 Qualification Requirements ................................................. 25

5.11.2 Role of the Payroll Organization ................................................ 26

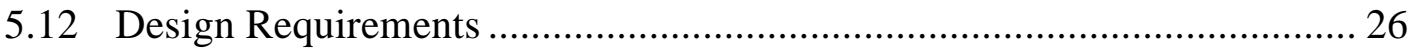

5.12.1 Engineering Design Review Records ....................................... 27

5.12.2 Drawing and Sketch Control .................................................. 27

5.12 .3 Inspection Reports .......................................................... 27

5.12.4 Historical Files ...................................................................... 27

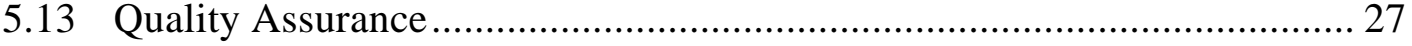

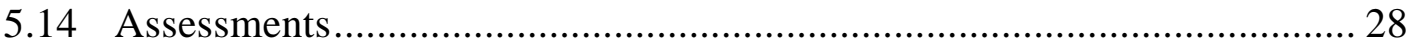

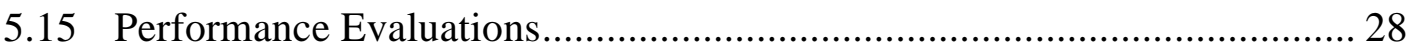

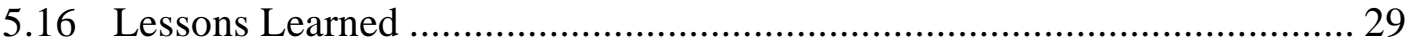

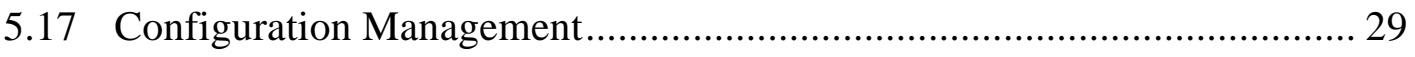

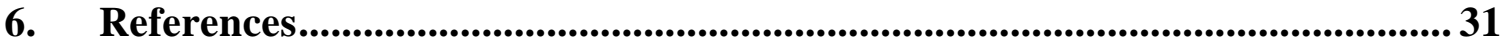

Attachment 1. N Program ISM Requirements Matrix................................................. 35 


\section{Acronyms}

\begin{tabular}{|c|c|}
\hline AA & Activity Agreement \\
\hline $\mathrm{AD}$ & Associate Director \\
\hline BEEF & Big Explosives Experimental Facility \\
\hline $\mathrm{BN}$ & Bechtel Nevada \\
\hline DAF & Device Assembly Facility \\
\hline DNT & Defense and Nuclear Technologies \\
\hline $\mathrm{DOE} / \mathrm{NV}$ & Department of Energy/ Nevada Operations Office \\
\hline DSED & Defense Sciences Engineering Division \\
\hline DTED & Defense Technologies Engineering Division \\
\hline DTRA & Defense Threat Reduction Agency \\
\hline EMP & Emergency Management Program \\
\hline $\mathrm{ES} \& \mathrm{H}$ & Environment, Safety, and Health \\
\hline ETA & Experimental Test Accelerator \\
\hline FSP & Facility Safety Plan \\
\hline HEDP & High-Energy-Density Physics \\
\hline HR & Human Resources \\
\hline ISM & Integrated Safety Management \\
\hline IWS & Integrated Work Sheet \\
\hline JASPER & Joint Actinide Shock Physics Experimental Research \\
\hline JTO & Joint Test Organization \\
\hline LANL & Los Alamos National Laboratory \\
\hline LLNL & Lawrence Livermore National Laboratory \\
\hline N Program & Nevada Experiments and Operations Program \\
\hline NIF & National Ignition Facility \\
\hline NTO & Nuclear Test Operations \\
\hline NTS & Nevada Test Site \\
\hline OSP & Operational Safety Plan \\
\hline QA & Quality Assurance \\
\hline REOP & Real Estate and Operations Permit \\
\hline
\end{tabular}


RTBF Readiness in Technical Base and Facilities

S\&S Safeguards and Security

SAR Safety Analysis Report

SCE Subcritical Experiment

SNL Sandia National Laboratories

UC University of California

WBS Work Breakdown Structure

WSI Wackenhut Services Incorporated

WSS Work Smart Standard

YMPO Yucca Mountain Project Office 


\section{Introduction}

The Nevada Experiments and Operations Program (N Program) is a programmatic element of the Defense and Nuclear Technologies (DNT) Directorate at Lawrence Livermore National Laboratory (LLNL). N Program provides the interface between LLNL and the U.S. Department of Energy's Nevada Operations Office (DOE/NV). Major responsibilities include managing and executing large experiments at the Nevada Test Site (NTS) in support of DOE's Stockpile Stewardship Program and meeting LLNL institutional commitments for activities in Nevada. N Program also manages the application of DOE/NV resources to LLNL activities, including the assets provided by the DOE/NV performance-based management and operating contractor, Bechtel Nevada (BN). Activities in Nevada take place either in North Las Vegas or at the NTS. A component of N Program's work is performed at other sites such as the LLNL Livermore and Site 300 locations.

By their very nature, $\mathrm{N}$ Program experiments usually involve potential hazards and risks that go well beyond those normally experienced by the general public. Materials associated with these experiments may have radioactive, toxic, and/or explosive properties. One component of the approach taken to manage these risks is to conduct the experiments at a remote location - the NTS being the site of choice. In reality, the NTS is the only U.S. site where many N Program activities may be conducted. Generally, other programmatic elements of the Laboratory conceive and design the experiments. $\mathrm{N}$ Program provides the vehicle for conducting the experiments, including preparation of the test site, installation and set-up of testing equipment, and provisions for operations and execution support.

\subsection{Purpose}

This plan briefly describes the LLNL institutional structure and how N Program's organization fits within this structure, roles and responsibilities, and management processes that govern N Program activities. This plan also serves as the Integrated Safety Management (ISM) Implementation Plan for N Program work.

\section{$1.2 \quad$ Scope}

This plan applies to all work performed by and for LLNL that falls under the oversight of DOE/NV except LLNL activities in support of the Yucca Mountain Project Office (YMPO). 


\section{LLNL Institutional Structure}

LLNL is structured into 10 directorates, each headed by an Associate Director (AD). The various directorates have responsibilities for technical programs, personnel, facilities, and support services. Each directorate may have responsibilities in one or several of these categories. The DNT AD has a strong role in the first three areas, and has an additional responsibility for integrating other directorate program requirements at two LLNL sites outside the main Livermore site.

Four areas of directorate responsibility are defined in the LLNL Integrated Safety Management System Description (LLNL 1999):

- Program: The programs initiate work. Each program decides what work needs to be done to achieve its objectives, establishes priorities for the work, decides what cost level is acceptable for a given objective, and decides when the work must be completed.

- Payroll: The payroll organization accepts the work to be done for the programs. The payroll organization decides which job skills are required to perform the work, which employees to assign, whether work can be done safely, how long it will take to accomplish the scope of work, and how much the personnel will cost. The payroll organization establishes and maintains the personnel safety envelope.

- Facility: The facility organization accepts work into the facility or work area. This organization decides whether the proposed work meets governing requirements, decides when the facility or work area is available, coordinates projects to avoid/resolve safety and resource conflicts, and determines the necessary qualifications to perform work in the facility. The facility organization establishes and maintains the facility safety envelope.

- Services: Service organizations perform work autonomously. Work assigned to service organizations is analogous to contract work and is generally welldefined projects that require skilled trades or crafts. The service organization is responsible for the safety, quality, and schedule of its work, and assures the competence of its people.

In addition to the four basic areas of responsibility, the DNT AD functions as the Site AD for Site 300, the LLNL high-explosives firing site, and for LLNL-sponsored facilities and operations under DOE/NV oversight, primarily at the NTS but also at other appropriate locations. The site organization establishes the standards to which other directorate projects are executed and provides facility and service functions at Site 300 and in 
Nevada for the broader LLNL user base. It assures that LLNL ISM elements are established and practiced at these remote locations.

\section{N Program Description}

\subsection{N Program Structure}

The N Program Office consists of the Program Leader, Deputy Program Leader, Program Administrator, Resource Manager, and clerical staff. A small group of senior engineers, assigned directly to the Program Office, fulfills the roles of Test Directors and Nuclear Test Operations (NTO) Resident Manager.

As the majority of N Program's work is field operations and engineering, the bulk of the technical staff is matrixed to the Program from the Engineering Directorate. The NTO, a group of employees who support operations at the NTS, is a major component of the engineering staff assigned to support $\mathrm{N}$ Program by the Defense Technologies Engineering Division (DTED). Dedicated electronics engineering support is provided by the Defense Sciences Engineering Division (DSED). Additional engineering support, usually involving special skills and knowledge, is provided to the Program by the Engineering Directorate on an ad hoc basis.

Other Laboratory payroll directorates, such as Earth and Environmental Sciences, provide support to N Program on a sustained and/or ad hoc basis, as required.

Figure 1 shows an organization chart for N Program. 


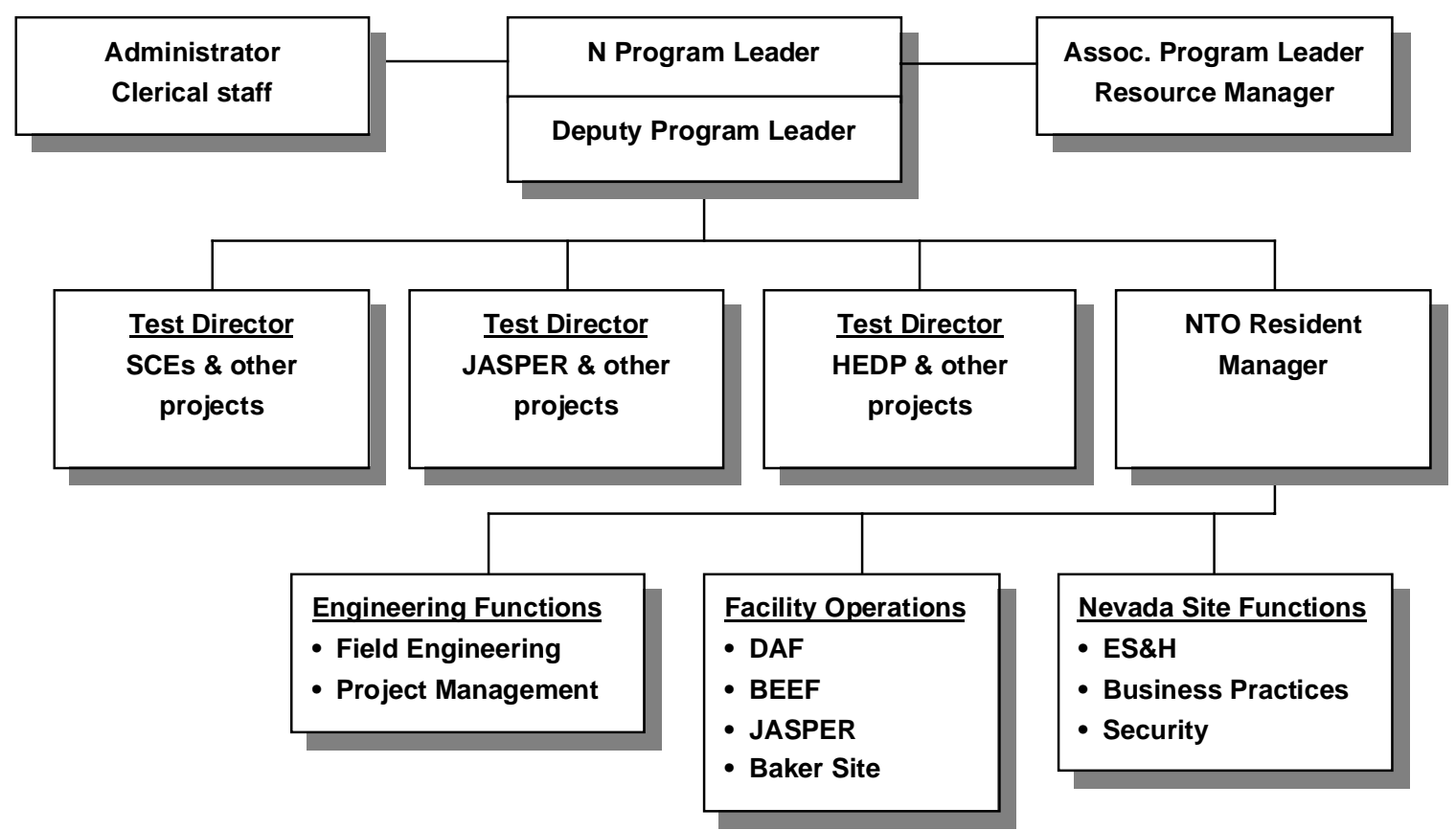

Figure 1. N Program organization chart.

\subsection{DOE/NV Contractor Interfaces}

\subsubsection{Bechtel Nevada}

$\mathrm{BN}$ provides considerable technical and craft manpower to support $\mathrm{N}$ Program activities in Nevada as well as at other DOE work sites. Some BN employees are assigned in a dedicated fashion to LLNL N Program activities; others are assigned on an ad hoc basis. In this capacity, BN serves the role as a payroll or service organization. For BN employees performing work at LLNL, N program functions as the payroll organization, accepting work from other LLNL Programs and allocating the appropriate BN resources to its execution. Although no direct contractual agreement exists between BN and LLNL, $\mathrm{N}$ Program assures the safe execution of project activities involving these two organizations through mechanisms described in this document. BN retains the payroll functions of assigning appropriately trained people to the work, determining costs and schedules, and ultimately assuring the safety of their employees.

\subsubsection{Wackenhut Services, Incorporated}

Wackenhut Services, Incorporated (WSI) is the DOE/NV security contractor and predominantly fulfills a service role in its interactions with LLNL. WSI also provides technical support in the field of communications systems. 


\subsection{Technical Focus Areas}

N Program is functionally organized around three primary technical areas. On the project side, a Test Director leads each focus area. Each focus area is currently a major component of the DNT Stockpile Stewardship experimental effort. The technical areas are:

- Subcritical Experiments (SCEs)

Conducted in the underground U1a Complex at the NTS, the LLNL SCE Program provides unique data on the material properties of plutonium when shocked by a high explosive detonation. The experiments are conducted in sealed chambers specifically designed to contain the expended plutonium during and after the detonation. Diagnostics are tailored to the specific experiments and can include holographic or radiographic imaging systems, high-speed rotary and image conversion cameras, a multi-channel Fabry-Perot velocimetry system, piezoelectric and contact pins, energy output measurements, and a variety of environmental sensors to support postexecution operations.

- JASPER Facility

Currently under development at Able Site in Area 27 of the NTS, the Joint Actinide Shock Physics Experimental Research (JASPER) Facility will provide a capability to evaluate properties of materials such as plutonium and uranium under extreme pressure conditions. The heart of the facility is a specially configured two-stage gas gun. The facility is scheduled for completion in 2001. LLNL leads this development activity. Following startup, the NTO will manage and operate JASPER.

- High-Energy-Density Physics

High-energy-density physics (HEDP) experiments are planned for the National Ignition Facility (NIF) in support of the Stockpile Stewardship mission. $\mathrm{N}$ Program manages the $\mathrm{BN}$ resources applied to this effort and is also tasked with the development and construction of HEDP x-ray and neutron diagnostics for the NIF target chamber system. Additional activities include the development of new radiographic techniques on such facilities as the Experimental Test Accelerator (ETA). 
In addition to these primary assignments, each Test Director may take on other project assignments, including:

- High explosives testing.

- High explosives/ nuclear explosives operations, including assembly, disassembly, storage, handling, and transportation (onsite at NTS).

- Timing and firing.

- Experiment diagnostics, including high-speed optical and radiographic systems, and radiation measurements.

- Development of improved radiographic sources.

The Program Office maintains a current list of N Program projects and operations. This list identifies the responsible senior $\mathrm{N}$ Program manager and key requirements documentation for each project.

\subsection{Facility Focus Areas}

LLNL has exclusive use of various low- and moderate-hazard facilities and rooms at several locations in North Las Vegas and at the NTS. In addition, LLNL manages four major operations facilities for appropriate user communities. Facility management and operations is assigned to the NTO Resident Manager, who further assigns a Facility Manager or other facility point of contact, as required. Details are provided in Section 5.6.

\subsection{Nevada Site Operations}

N Program is the institutional representative for LLNL activities at the NTS. This site management responsibility is described in detail in Section 5.5.

\section{Roles and Responsibilities}

The DNT AD is accountable to the Laboratory Director for ensuring that programmatic goals are met and that DNT program, facility, and payroll activities are performed in accordance with LLNL environment, safety, and health $(\mathrm{ES} \& \mathrm{H})$ requirements (LLNL 2000). For LLNL work that is performed using DOE/NV resources, the DNT AD assigns these responsibilities to the N Program Leader.

The N Program Leader assigns responsibility for meeting LLNL ES\&H requirements through two primary mechanisms: (1) Project work is assigned to the responsible Test Director or NTO Resident Manager; and (2) ES\&H responsibility for all other activities 
at the NTS, such as facility operations, is assigned to the NTO Resident Manager. In each case, the responsible individual may further assign ES\&H responsibilities to lead individuals (e.g., supervisor, group leader, or lead/project engineer) at the facility and activity level. This approach is incorporated into the definitions of responsibilities that follow.

\subsection{Program Leader/Deputy Program Leader}

The N Program Leader reports directly to the DNT AD and is assigned programmatic, payroll, and facility responsibilities. The Deputy Program Leader supports the Program Leader in carrying out these responsibilities and is authorized to act in his/her stead. Responsibilities include:

- Define the scope of programmatic work, including establishing the technical objectives.

- Define the LLNL mission for DOE/NV resources, translate the mission into work, set expectations, and establish priorities.

- Allocate sufficient resources (both LLNL and DOE/NV) to ensure safe and compliant operations, including safety training.

- Assure operational, safety, and administrative integration with DOE/NV and its contractors.

- Provide input to $\mathrm{DOE} / \mathrm{NV}$ for the periodic performance evaluation of $\mathrm{BN}$.

- Conduct self-assessments to evaluate program ES\&H and quality assurance (QA) issues, consistent with the requirements of the DNT Self-Assessment Plan (DNT 1999a).

- Implement the QA requirements set forth in the DNT QA Plan (DNT 1995) within N Program.

- Assure safety and performance standards are established prior to authorizing work.

- Assure that personnel involved in an activity have the opportunity to participate in the development of work controls for that activity.

- Clearly define the responsibilities of key positions of the program.

- Serve as a DOE/NV designated official for purposes of providing technical direction to DOE/NV contractor employees consistent with the provisions of their contracts (see Section 5.3.1). 
- Assure that the management chain is defined for each work activity.

- Assure the implementation of a lessons-learned program consistent with LLNL policy and requirements.

\subsection{Test Director}

A Test Director is a member of the N Program senior staff. His/her primary responsibility is to manage and execute major LLNL projects that use DOE/NV resources. He/she will:

- Integrate the efforts of a multidisciplinary team of scientists, engineers, and technical staff in planning and executing major experiments/tests.

- Serve as the LLNL point-of-contact for DOE/NV on assigned projects.

- Serve as a DOE/NV designated official for purposes of providing technical direction to DOE/NV contractor employees consistent with the provisions of their contracts (see Section 5.3.1).

- Exercise line management responsibility for safety at the project level, including:

- Prepare a project plan, which includes the development and maintenance of the project budget and schedule.

- Assure that the hazards associated with the project are identified and clearly understood.

- Assure that tailored controls are developed for each hazard associated with the work activity. This includes involving the worker in the development of the controls.

- Approve the work controls, including assuring that all required project documentation is prepared and approved for use in a timely manner.

- Assure that all required technical, operational, prestart, and safety reviews are completed consistent with the project schedule.

- Assure that work is performed in accordance with approved controls.

- Assure that lessons learned for a given project or activity are captured and incorporated as necessary into future projects.

- Assure that personnel who work on the project have the necessary training and qualifications for their assignments. 
- Serve as the principal safety officer for the project.

- Execute signature authority for $\mathrm{N}$ Program accounts up to $\$ 100 \mathrm{~K}$.

- Assure that accidents and injuries are properly reported.

- Be able to qualify for the Personnel Assurance Program.

Certain projects conducted at the NTS are narrowly focused and are not closely related to the Stockpile Stewardship Program mission of most N Program projects. The N Program Leader may choose to assign project management responsibility for this type of project to an individual who is qualified as a Test Director only for the limited scope of the project. The responsibilities of this so-called "Limited-Scope Test Director" are the same as those of the Test Director.

\subsection{Nevada Test Organization Resident Manager}

The NTO Resident Manager is the Site Manager for LLNL activities conducted in Nevada. He/she is also a Section Leader in DTED. Thus, he/she has certain payroll directorate responsibilities that are assigned by DTED. The listing below defines only the programmatic responsibilities assigned by $\mathrm{N}$ Program:

- Provide site support for the implementation of Integrated Safety Management into LLNL activities at DOE/NV Nevada locations.

- Maintain and oversee ES\&H functions that are required for the safe and responsible work of LLNL at DOE/NV Nevada locations.

- Assure the availability and accessibility of LLNL and DOE/NV Nevada assets to LLNL users.

- Provide LLNL concurrence for work authorization in Nevada.

- Oversee all NTS facility operations for which N Program has management responsibility.

- Interface with DOE/NV as a representative of $\mathrm{N}$ Program.

- Serve as a DOE/NV designated official for purposes of providing technical direction for DOE/NV contractor employees consistent with the provisions of their contracts (see Section 5.3.1).

- Serve as the LLNL Operations Officer to the DOE/NV Joint Test Organization. 
- Create and maintain all documentation required for N Program operations at the NTS.

- Assume content responsibility for Volume VI: "Nevada Requirements" of the LLNL ES\&H Manual.

- Manage the incident and occurrence reporting process for LLNL operations at the NTS.

- Manage the lessons learned program for N Program.

- Conduct self-assessments to evaluate the status of ES\&H and QA issues associated with LLNL operations at the NTS, consistent with the requirements of the DNT Self-Assessment Plan (DNT 1999a).

- Execute signature authority for N Program accounts up to $\$ 100 \mathrm{~K}$.

- Serve on the N Program senior staff and take on any special assignments as required.

\subsection{Facility Manager}

The DNT AD serves as the Facility AD for several facilities at the NTS. N Program is assigned facility management responsibilities for those facilities. The Facility Managers are accountable to the NTO Resident Manager for assuring that facility operations are performed safely. Each Facility Manager will:

- Establish and maintain the facility safety envelope, including development of all facility safety and operating documentation (e.g., Facility Safety Plans [FSPs], Operational Safety Plans [OSPs], etc.).

- Assure that personnel performing work in the facility are adequately qualified.

- Assure that the work authorization process for facility and project work is properly executed.

- Assure that facility work is performed in accordance with approved work controls.

- Assure that proper and adequate ES\&H support is available consistent with the requirements of the work being performed.

- Participate in post-operation evaluations and assure that lessons-learned results are incorporated into facility operations. 
- Periodically review work areas and operations for ES\&H and QA compliance by formal and informal self-assessments, consistent with the requirements of the DNT Self-Assessment Plan (DNT 1999a).

- Implement the QA requirements set forth in the DNT QA Plan (DNT 1995) within the facility. A facility-specific QA plan may be required.

\subsection{Project Leader}

The N Program Leader or Test Director may designate project status to a component of programmatic work to be performed at the NTS or other work sites. The assigned Project Leader will:

- Serve as the LLNL point-of-contact for DOE/NV on assigned projects.

- Exercise line management responsibility for safety at the project level, including:

- Prepare a project plan, which includes the development and maintenance of the project budget and schedule.

- Assure that the hazards associated with the project are identified and clearly understood.

- Assure that tailored controls are developed for each hazard associated with the work activity. This includes involving the worker in the development of the controls.

- Approve the work controls, including assuring that all required project documentation is prepared and approved for use in a timely manner.

- Assure that all required technical, operational, prestart, and safety reviews are completed consistent with the project schedule.

- Assure that work is performed in accordance with approved controls.

- Assure that lessons learned for a given project or activity are captured and incorporated as necessary into future projects.

- Assure that personnel who work on the project have the necessary training and qualifications for their assignments.

- Execute signature authority for $\mathrm{N}$ Program accounts up to the dollar level that is authorized for the project.

- Assure that accidents and injuries are properly reported. 


\subsection{Technical Supervisor}

Technical supervisors direct or oversee work at the activity or facility level. A technical supervisor may have other responsibilities assigned by his/her payroll organization. A technical supervisor will:

- Assure that personnel have the qualifications necessary for their job assignment, including safety training.

- Assure that tailored controls are developed for each hazard associated with the work activity. This includes involving the worker in the development of the controls.

- Assure that work is performed in accordance with defined work controls (e.g., governing procedures, safety documents, etc.).

- Assure that accidents and injuries are properly reported.

\subsection{Individual Worker}

Each individual who performs work for N Program is responsible to:

- Ensure his/her own safety and safety of others who could be impacted by his/her actions.

- Bring to the attention of his/her immediate supervisor safety concerns, problems with the applicable operating limits and/or controls, and opportunities for improvement associated with the work or governing procedure(s).

- Participate in the development of work controls relevant to his/her particular assignment.

- Stop work if there is an unsafe or unapproved condition.

- Ensure that accidents and injuries are properly reported.

- Possess the necessary skills, knowledge, and abilities (SKAs), including physical capabilities, to carry out assigned tasks.

\subsection{Special Positions}

\subsubsection{Scientific Advisor}

The Scientific Advisor chairs the DOE/NV Test Controller's Scientific Advisory Panel, which convenes for each nuclear test and subcritical experiment. The panel advises the 
Test Controller on experiment features that could impact the safety of on-site and off-site populations and recommends actions as appropriate. Candidates are nominated by the N Program Leader and approved by the DOE/NV Manager. The Scientific Advisor will:

- Understand the technical and scientific aspects of each experiment, including safety and control procedures.

- Consult with individuals, Laboratories, and participating agencies involved in the execution of each experiment, as required, to advise and recommend action to the Test Controller to assure safety in experiment execution.

- Participate in documentation of the panel's action by providing input and reviewing minutes of panel meetings.

\subsubsection{Associate Program Leader}

The Associate Program Leader serves as the primary interface between N Program and DOE/NV and between N Program and BN for administrative and budgetary matters. The Associate Program Leader will:

- Represent N Program in the process to manage DOE/NV resources that are directed toward the accomplishment of Stockpile Stewardship missions.

- Represent N Program in the DOE/NV evaluation of BN's performance.

- Participate in the DOE/NV out-year budget development process.

- Manage the N Program component of the Readiness in Technical Base and Facilities (RTBF) Plan.

- Serve as the N Program point-of-contact for the LLNL Stockpile Stewardship campaign efforts.

\subsection{Engineering Directorate}

The Engineering Directorate is the principal payroll directorate for $\mathrm{N}$ Program. N Program expects the engineering divisions to fulfill the following responsibilities:

- Matrix personnel to N Program assignments who have the necessary skills, knowledge, and abilities (SKAs) to successfully and safely perform their assignments.

- Provide management approval for actions and decisions made by matrixed Engineering personnel. 
- Establish, maintain, and apply design standards and criteria that assure compliance with the ES\&H Manual (LLNL 2000).

- Assure that the work of its personnel meets the standards and requirements established for the work. Conduct design reviews and assessments to assure compliance.

- Develop and maintain execution plans for each project or support activity.

- Involve $\mathrm{N}$ Program management in its evaluation of the performance of its personnel who support N Program.

\subsection{Bechtel Nevada}

$\mathrm{BN}$ is the principal DOE/NV contractor interacting with LLNL. N Program expects BN to fulfill the following:

- Assign personnel to N Program who have the necessary skills, knowledge, and abilities (SKAs) to successfully and safely perform their assignments.

- Provide management approval for actions and decisions made by assigned personnel.

- Use design standards and criteria as specified by LLNL.

- Assure that the work of its personnel meets the standards and requirements established for the work. Participate in design reviews and assessments to assure compliance.

- Develop and maintain execution plans for each project or support activity.

- Solicit input from appropriate LLNL program and project managers in its evaluation of the performance of its personnel who support N Program.

- Provide accurate, relevant, and timely reports to LLNL on technical accomplishments, project status, and cost.

- Maintain change control processes to track changes in scope, schedule, and budget.

\subsection{Wackenhut Services, Incorporated}

As a service organization, WSI is responsible for the safety, quality, and schedule of its work, and assures the competence of its people. 


\section{Management Elements}

The following sections describe the principal elements or requirements of N Program's management program.

\subsection{Integrated Safety Management Requirements}

N Program embraces the LLNL safety goal, which is to "continuously strive for a healthy, accident free, and environmentally sound workplace and community while providing the scientific and technical excellence needed to meet critical national missions" (LLNL 1999). In this goal, safety is used synonymously with environment, safety and health to encompass protection of the public, the workers, and the environment.

The LLNL fundamental guiding ISM principle is that each worker, supervisor, and manager is directly responsible for ensuring his/her own safety and promoting a safe, healthful, and environmentally sound workplace and community.

DOE has defined five Core Functions for ISM that comprise the underlying process for any work activity that could potentially affect the public, the workers, and the environment. They are by title:

1. Define the scope of work

2. Analyze the hazards

3. Develop and implement hazard controls

4. Perform the work within controls

5. Provide feedback and continuous improvement

DOE has defined seven Guiding Principles that are the fundamental policies for DOE and its contractors to use in the management of safety. They are by title:

1. Line management responsible for safety

2. Clear roles and responsibilities

3. Competence commensurate with responsibilities

4. Balanced priorities

5. Identification of safety standards and requirements

6. Hazard controls tailored to work being performed

7. Operations authorization 
The LLNL institutional approach to ISM is established in the LLNL Integrated Safety Management System Description (LLNL 1999). ISM implementation for N Program is established at the high level through the DNT Integrated Safety Management Implementation Plan (DNT 1999b). This document, the N Program Management Plan, serves as the specific ISM implementation plan for the work of $\mathrm{N}$ Program. Attachment 1, the N Program ISM Requirements Matrix, assesses how N Program addresses the Laboratory requirements consistent with DNT implementation actions.

DOE/NV has established its commitment and approach to integrating ISM throughout the DOE/NV complex through the issuance of its Safety Management System Policy, which serves as the DOE/NV ISMS Description (DOE 1999h). In it, DOE/NV recognizes LLNL as a primary user of the NTS.

\subsection{Work Smart Standards}

LLNL is contractually required to operate consistent with the terms of Prime Contract W-7405-ENG-48, the agreement by which the University of California (UC) operates the LLNL for the DOE. Contract 48 requires adherence to all applicable laws, regulations, orders, and directives in the performance of work. The standards and requirements by which LLNL performs work are established in a set of Work Smart Standards (WSS), which are listed in Appendix G of Contract 48.

DOE/NV has defined a set of standards and requirements that form the basis for performing work at the NTS. In a letter to the Director of LLNL, DOE/NV affirms its policy “...that all LLNL personnel working at DOE/NV facilities must comply with all applicable DOE/NV policies; Orders and Directives: federal laws and regulations; and state and local laws relating to ES\&H, [Safeguards \& Security], [Emergency Management Program], and QA including DOE/NV Work Smart Standards (WSS) or other applicable DOE/NV approved standards" (DOE 1999f). An effort is under way to identify the differences between the LLNL WSS and DOE/NV standards sets and to develop a mechanism for resolving the differences (see Section 5.2.1). Additional standards will be incorporated in the proper context into the WSS set in Contract 48.

LLNL has established the ES\&H Manual as the source document for ES\&H-related performance requirements and policy information that is to be used in the conduct of Laboratory work. Work performed in conformance with the ES\&H Manual meets the requirements of the LLNL WSS set. Unique requirements that apply to work in Nevada have been incorporated into Volume VI of the ES\&H Manual, "Nevada Requirements." The ES\&H Manual includes provisions to authorize work that is not explicitly covered by the contents of the Manual. 


\subsubsection{Authorization for Interim Operations}

While LLNL and DOE/NV are developing appropriate WSS for LLNL activities currently exempted or otherwise excluded from the DOE/NV WSS set, it is necessary to provide standards and procedures to assure the safety of those operations. WSS that differ from the currently approved LLNL set will be reviewed and approved by the Change Control Group.

Interim operations will be conducted in accordance with the following documents:

- NTO Administration Plans and Procedures Manual.

- $\quad$ NTO Environment, Safety, and Health Plans and Procedures Manual (LLNL ES\&H Manual, Volume VI).

- Area 27-Baker Site Safety Plan.

- Big Explosives Experimental Facility Safety Plan.

- Device Assembly Facility plans and procedures.

- SCE procedures.

Operations conducted in accordance with the above documents will meet the additional requirements of applicable DOE/NV WSS as well as supplemental lists of DOE and DOE/NV directives, which are applicable to work categories that were exempt from the 1995 DOE/NV application of WSS, known as the B-2 and B-3 lists.

\subsection{Relationship with DOE/NV}

DOE/NV uses several mechanisms to assign authority and responsibility to LLNL for the control of programmatic work at the NTS. Although DOE/NV does not have a direct contractual relationship with LLNL (or the UC), a management agreement between DOE/NV and the DOE Oakland Operations Office (DOE/OAK, formerly the San Francisco Operations Office) enables DOE/NV to establish responsibilities and requirements and to exercise oversight for LLNL activities in Nevada (DOE 1990).

\subsubsection{Delegation of Designated Officials}

Delegation letters between the Manager, DOE/NV and the Director of LLNL assign certain authorities and responsibilities to LLNL personnel for specific activities at the NTS (DOE 1999d, e, i). These letters identify LLNL personnel in several job assignments as "Designated Officials of DOE/NV," which authorizes them to provide performance direction for $\mathrm{BN}$ and other contractor activities. This assignment focuses on the 
establishment of safety programs and the conduct of operations. Specific duties relating to the LLNL-BN interface include providing technical direction, monitoring technical compliance, and resolving technical differences. The N Program Leader nominates LLNL personnel for these assignments.

Technical direction is defined as instructions necessary to execute authorized work in order to meet program objectives. Technical direction may not result in violation of laws, directives, orders, policies, or contractual provisions, nor may it cause the contractor to incur costs beyond the level authorized by DOE/NV for the overall Laboratory program or beyond the level authorized for a specific scope of work. Limited technical direction further restricts authorized changes to those within the specific project budget authorization. Designated officials may reassign this authority to assure "full and open communication between the functional counterparts of the DOE, the National Laboratories, and the contractor organization. Such communication will facilitate a clear and consistent understanding of the technical and performance requirements of the work and will result in accomplishment of the work in a highly professional, coordinated, efficient, and cost-effective manner" (DOE 1996).

The management and operation of DAF and BEEF and the conduct of test readiness activities are currently governed by such delegation letters. These letters are subject to regular review and revision. New letters may be established as required by programmatic requirements.

\subsubsection{Activity Agreements}

Activity Agreements (AAs) executed between the Manager of DOE/NV and the DNT AD define facilities and activities at the NTS (and potentially at other NV sites) for which LLNL is given management and safety coordination responsibility (DOE 1999a-c). These agreements establish that LLNL is assigned to manage specified facilities. They further define roles and responsibilities for each organization supporting the operation of the facilities and the execution of work. Each organization retains responsibility for the qualification, competence, and safety of its employees but may be required by LLNL to provide appropriate evidence of compliance. For LLNL operations, the issuance of a Real Estate/Operations Permit signifies DOE/NV recognition of the completion of the required LLNL safety planning and documentation.

\subsubsection{Real Estate/Operations Permits}

The Real Estate/Operations Permit (REOP) is the mechanism by which DOE/NV authorizes an NTS user organization to conduct well-defined activities associated with 
managing and operating a facility or executing a project operation. The REOP is similar to a license to operate (DOE 1999g).

\subsection{Payroll and Technical Staff Management}

N Program serves as the payroll organization for employees assigned from the DNT Directorate (Payroll Account 9800), including the Program Leader, Deputy Program Leader, Resource Manager, Administrator, and clerical staff. Although performance assessment and salary management remain the responsibility of the home directorate, N Program provides necessary input.

$\mathrm{N}$ Program also represents DOE/NV as the payroll organization for DOE/NV contractor personnel performing work at LLNL. Responsibilities include establishing and maintaining the personnel safety envelope by assuring that training plans are developed and completed, necessary safety equipment is available, and execution plans are prepared. These responsibilities are defined through a Memorandum of Understanding between LLNL and BN to ensure that responsibilities are clearly understood. On behalf of the DOE/NV Manager, N Program evaluates work requests and execution plans to assure that the assigned DOE/NV contractor personnel can perform the work safely and adequately. N Program approval or concurrence is required on any execution plan, OSP, or Integrated Work Sheet (IWS) involving DOE/NV contractor personnel at LLNL.

\subsection{Site Management}

For purposes of work authorization and safety management, LLNL considers its DOE/NV facilities in Nevada to be a site. A site is a logical grouping of facilities, locations, and activities assigned to a directorate for oversight of all LLNL activities. Operations at a designated site or included facility are exempt from the LLNL off-site OSP policy. An off-site OSP is neither required nor allowed for work authorization and safety management. Instead, the normal OSP, FSP, and IWS are prepared and submitted to the cognizant directorate for approval. Both LLNL sites, NTS and Site 300, are assigned to DNT. In this context, the NTO Resident Manager serves as "Site Manager" for LLNL activities in Nevada.

In the case of DOE/NV resources assigned to support LLNL programmatic objectives, the DNT AD and the DOE/NV Manager have designated the N Program Leader as the responsible manager for work authorization, safety management, and personnel oversight. Following the work authorization process (see Section 5.10) and the payroll/technical staff description in Section 5.4, N Program must approve or concur on all OSP, FSP, and IWS for work involving DOE/NV assets. N Program will approve 
application for and will hold any DOE/NV REOP for LLNL activities in Nevada or for use of DOE/NV resources on other LLNL activities.

N Program assures the DOE/NV Manager that approved LLNL operations comply with the LLNL ES\&H Manual, WSS, applicable DOE/NV orders and regulations, and other requirements. In addition, these operations are properly integrated into DOE/NV coordinating, monitoring, assessment, and reporting systems. N Program will assign a senior manager (Test Director or NTO Resident Manager) to each project activity. The NTO Resident Manager is assigned overall responsibility for all other activities.

\subsection{Facility Management}

LLNL has exclusive use of various low- and moderate-hazard facilities and rooms at several locations in North Las Vegas and at the NTS. In addition, LLNL manages four major operations facilities for appropriate user communities. Facility management and operations is assigned to the NTO Resident Manager, who further assigns a Facility Manager or other facility point of contact, as required.

\subsubsection{Major LLNL Facilities at NTS}

Certain facilities and sites are used to conduct complex experiments and operations at the NTS. These include both the facilities where the experiments are prepared and staged and the testing sites. From the start of its involvement in nuclear explosives testing at the NTS, LLNL has directly managed and operated these major facilities and sites as an integral part of its safe and successful conduct of operations. This philosophy continues today, with N Program managing and operating NTS facilities that are key to the execution of certain DNT projects. Formal DOE/NV recognition of LLNL authorities at these facilities is documented in the Activity Agreements (see Section 5.3.2). Facilities that are managed and operated by $\mathrm{N}$ Program include:

- Big Explosives Experimental Facility: BEEF is a hydrodynamics test facility similar to those located at the LLNL Site 300. Tests involving thousands of pounds of high explosives may be executed.

- Device Assembly Facility: The DAF is the NTS facility that is approved for the conduct of nuclear explosive assembly operations. It is jointly operated by LLNL and LANL, with the Laboratory of the Facility Manager (currently an LLNL employee) having principal management responsibility.

- Baker Site: Located in Area 27, Baker Site is approved for high explosive assembly and staging operations. 
- Joint Actinide Shock Physics Experimental Research Facility: JASPER is a two-stage light-gas gun facility that is designed for experiments involving actinide targets. The facility is currently being developed, with completion expected in 2001. (An Activity Agreement will be developed prior to authorization to operate.)

\subsubsection{Other NTS Facilities}

N Program has facility management responsibility for a number of general-purpose buildings or facilities at the NTS. These include all or portions of office buildings, warehouses, technical work spaces, and other areas. In total, LLNL has a proprietary interest in about 35 such facilities.

\subsubsection{Facilities Managed by Other Organizations}

LLNL also conducts experimental activities in NTS facilities that are managed and operated by other organizations. Examples include the U1a underground test complex, which is operated by LANL; and the HAZMAT Spill Facility, which is operated by BN.

\subsection{Representation in Joint Test Organization}

N Program is the LLNL representative to the DOE/NV Joint Test Organization (JTO). The JTO was established to facilitate a cooperative working environment among the primary user organizations of the NTS. It serves as a forum for working issues of mutual interest, such as schedule interactions, and the sharing of commonly used assets for the sake of economy. A mutually approved charter is in place, naming the DOE/NV Assistant Manager for National Security as the cognizant federal official. The other members of the JTO are LANL, SNL, and the Defense Threat Reduction Agency (DTRA). The N Program Leader serves as the senior LLNL JTO representative; the NTO Resident Manager serves as the LLNL JTO Operations Officer.

\subsection{Funding/ Balanced Priorities}

$\mathrm{N}$ Program accomplishes its assigned responsibilities through the management and expenditure of resources. The $\mathrm{N}$ Program Leader is responsible for maintaining a balance of priorities, assuring safety, while meeting programmatic requirements within security and other constraints.

\subsubsection{Direct Funding}

DNT provides the majority of funding for the execution of N Program work by Laboratory personnel. The primary source of this funding is DOE Defense Programs, 
with funds coming to DNT from both DOE Headquarters (e.g., DP-10) and DOE/NV. The latter funding assures the following skills and services are available for execution of projects in the DOE/NV interest:

- Test Directors.

- NTO Resident Manager.

- $\quad$ ES\&H support.

- Security advisor.

- $\quad$ Shipping, receiving, logistics support.

- High explosives, special nuclear material, and nuclear explosives services.

- Timing and firing expertise.

- Bunker operations.

In addition, a small amount of Work-for-Others funding comes to $\mathrm{N}$ Program through DNT each year. Finally, other LLNL programs may fund N Program effort in support of special projects that are conducted at the NTS.

\subsubsection{LLNL-Directed DOE/NV Funding}

A large portion of the effort to accomplish DNT DP objectives is supplied by BN. LLNL defines the program objectives to be supported by BN. BN then staffs appropriately to the program requirements and consistent with funding available through DOE/NV. $\mathrm{N}$ Program has the responsibility to oversee the management of these LLNL program resources. N Program works with DOE/NV and BN management to develop objectives and deliverables, allocate funding, track expenditures, and evaluate results.

\subsection{Hierarchy of Documents}

DNT has defined a hierarchy for the documents that establish and implement the requirements of its ISM program. As a program element of DNT, N Program draws upon this approach to define the hierarchy of documents that control its work. This hierarchy is illustrated in Figure 2. 


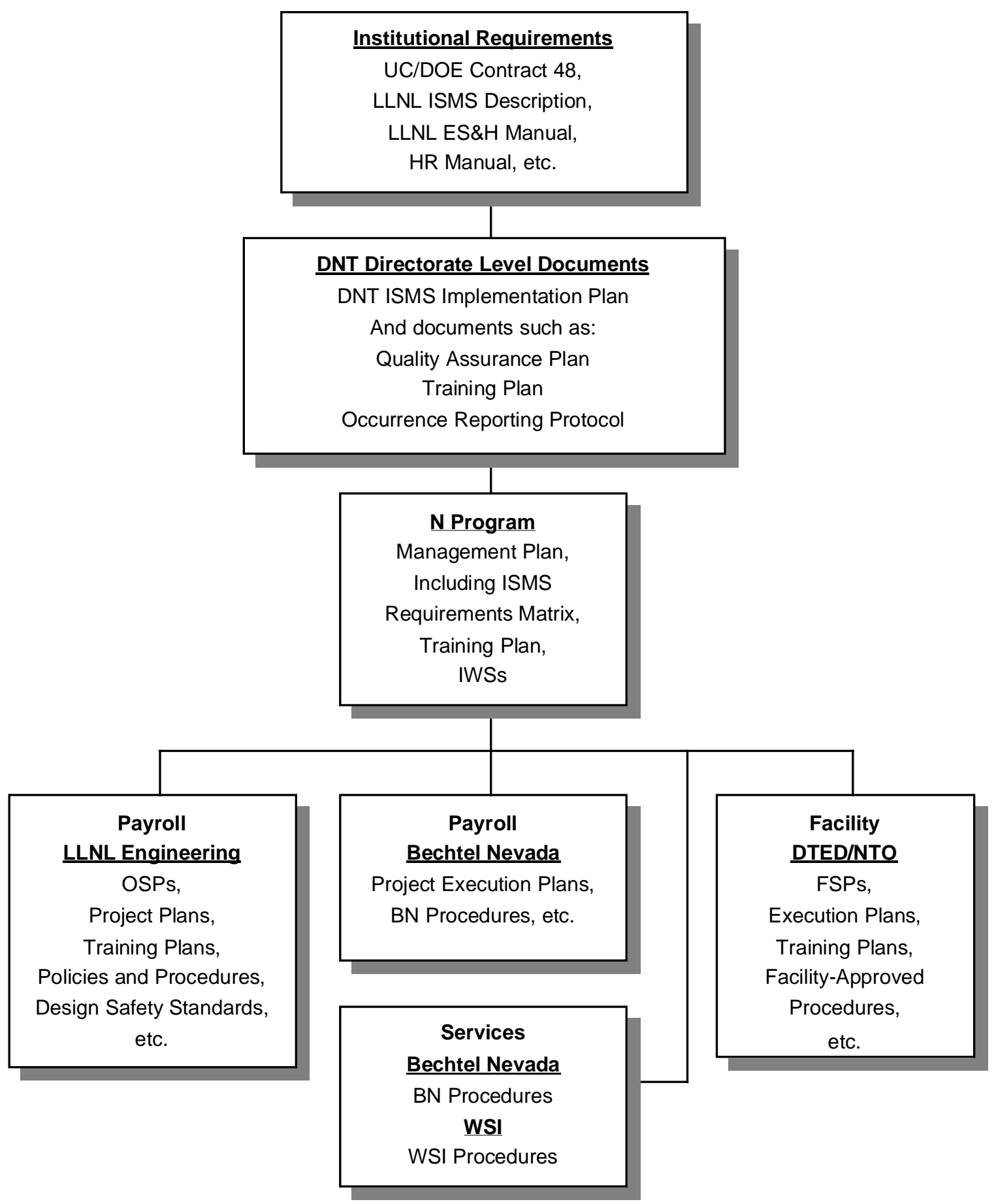

Figure 2. Hierarchy of documents. 


\subsection{Work Authorization Process}

\subsubsection{Flowdown of Requirements}

The scope of work in support of DOE/DP at LLNL is developed jointly by the senior Laboratory national security Associate Directors and DOE Defense Programs. The DNT Program Leaders then determine and prioritize how DOE/NV resources will be used to accomplish defined objectives. N Program works in concert with DOE/NV and the other user Laboratories to establish a balanced plan for the effective use of Nevada resources, including personnel, facilities, and equipment. DOE/NV defines the budget allocations for its operations and security contractors that are to be directed toward accomplishing Laboratory programs.

It is $\mathrm{N}$ Program policy that each LLNL activity that uses DOE/NV resources have a single $\mathrm{N}$ Program point of contact that represents the activity in the Nevada arena. For each major experimental or project activity, the N Program Leader assigns this project management responsibility to a Test Director. Likewise, the N Program Leader assigns responsibility for oversight of all other activities, including the operation of LLNLmanaged NTS facilities, to the NTO Resident Manager. The program element develops activity-level requirements for the safe and effective conduct of project and facility operations. The payroll organizations (BN and LLNL Engineering) then develop execution plans for their component of the work and assign resources.

\subsubsection{Line Management Responsibility for Safety}

N Program defines the management chains responsible for the safe execution of its work. For N Program activities, this generally takes two forms. For experimental or developmental project activities, responsibility passes from the N Program Leader to the Test Director and then to the Project Leader. For other operational activities and for institutional activities at the NTS (such as the LLNL management of NTS facilities), responsibility passes from the N Program Leader to the NTO Resident Manager to the Project Leader or Facility Manager. When acting in this capacity, the LLNL Test Directors and the NTO Resident Manager are assigned the role of "Designated Official" by the DOE/NV Manager. As such, they are responsible for establishing overall safety programs for the assigned activity and are empowered to provide technical direction to $\mathrm{BN}$. 


\subsubsection{Elements of the Authorization Process}

The LLNL work authorization processes are established in Section 7 of the LLNL Integrated Safety Management System Description (LLNL 1999). DOE/NV authorization to operate NTS facilities and perform work is granted through the issuance of a REOP (see Section 5.3.3).

\subsubsection{Facility Operations}

Four LLNL-operated facilities at the NTS have a hazard categorization that is higher than that of general industry. Work at BEEF and Baker Site can involve explosives and radiological materials. Work at DAF can involve explosives, fissile, and radiological materials. Work at JASPER will involve small quantities of actinide materials, explosives, and gun propellants. Each facility will be operated with controlling documentation that is consistent with the categorization level of the facility.

\subsubsection{Work Activities}

Work activities with hazard levels beyond those commonly experienced by the public or outside an approved authorization basis are performed in accordance with the requirements of OSPs, which address hazards and define work controls. The sponsor of the activity submits an IWS as a request for permission to conduct the activity. Laboratory authorization is granted through signature of the IWS at the appropriate level of the management chain, which includes the concurrence of the NTO Resident Manager for all work in Nevada.

\subsection{Qualification of Personnel}

Personnel who work on N Program projects and/or in facilities managed and operated by $\mathrm{N}$ Program must be qualified to perform the work to which they are assigned. This requirement applies to LLNL and contractor employees alike. In this context, the term "qualification" includes the requirements relating to the skills, knowledge, and abilities (SKAs) necessary to competently and safely perform the assigned work.

\subsubsection{Qualification Requirements}

The principal source of N Program qualification requirements is the $N$ Program Training and Qualifications Plan (N-Prog 1997). It addresses policy, process, and responsibilities associated with establishing a workforce that is qualified to perform the work of $\mathrm{N}$ Program. Formal training and qualification requirements are identified for many $\mathrm{N}$ Program work assignments. Training requirements are defined, recorded, tracked, and 
maintained using the institutional database system, LTRAIN. All N Program requirements and currency of training will be based on the LTRAIN database as the official record.

Several other sources define qualification requirements for $\mathrm{N}$ Program operations personnel:

- Project and facility-specific training and qualification requirements are defined in specific OSPs, FSPs, and training plans.

- The NTO Training and Qualifications Procedure (NTO 2000) establishes training and qualifications requirements for LLNL personnel who perform work at the NTS. It applies to both Nevada- and Livermore-based employees. Furthermore, it establishes the NTO approach to addressing training and qualification issues across the interface with $\mathrm{BN}$, primarily as it relates to $\mathrm{BN}$ employees who work in support of LLNL activities.

- Qualification requirements to work on a project or in a facility of another organization may be established by that organization.

\subsubsection{Role of the Payroll Organization}

N Program expects the payroll organization to provide personnel who have the necessary SKAs and safety-related training to perform the work of the program safely and competently. Attaining necessary or special SKAs and safety-related training, and maintaining a needed qualification status (e.g., required refresher training) are all considered to be a part of the job assignment. It is expected that the payroll organization will effectively manage this responsibility so that their personnel are properly qualified when they undertake N Program assignments.

\subsection{Design Requirements}

Work performed by or for N Program will conform to the design standards and practices of the LLNL Mechanical Engineering and Electronics Engineering departments (ENG 1993b, 1997, 2000). All work authorized by Engineering employees or by BN employees acting under their direction will meet these standards and will have the approval of Engineering management. The Engineering Directorate shall conduct design reviews and QA audits as appropriate to assure compliance. Any decision to override Engineering standards or review findings shall be concurred with by the appropriate $\mathrm{N}$ Program representative and shall not result in a violation of applicable WSS or allow an unacceptable risk to the environment, safety, or health. 
In the case of work performed by and for other programs, other standards consistent with the LLNL WSS may be applied subject to the approval of the cognizant N Program manager. N Program will employ the expertise of the Engineering Directorate in determining the adequacy of the proposed standards.

\subsubsection{Engineering Design Review Records}

The division or directorate that sponsors an engineering design review is responsible for documenting the outcome of the review in a design review report. This report defines action items and assigns them to a responsible individual. The resolution of each action item is documented, as is the record of acceptance by the Design Review Committee. These records are kept on file by the sponsoring Engineering organization. The requirements for design reviews and the resulting documentation are defined in Engineering Directorate documents (ENG 1993b, 1997).

\subsubsection{Drawing and Sketch Control}

Drawings or sketches shall be in conformance with LLNL Engineering standards and practices or the equivalent $\mathrm{BN}$ requirements. Modifications to safety or mission-critical equipment will be documented in as-built drawings. LLNL drawings and sketches will be processed through and archived in the LLNL Engineering Records Center.

\subsubsection{Inspection Reports}

Safety and mission-critical equipment shall have documented dimensional, material, performance, and calibration reports completed as appropriate.

\subsubsection{Historical Files}

Historical files allow experiments and operations to be reevaluated or repeated at a later time. As technologies and understanding develop, thorough documentation allows new questions to be asked and answered.

\subsection{Quality Assurance}

N Program embraces the DNT QA goal of providing a process for continuous improvement in all areas of performance with a continuing dedication to excellence. The DNT QA program is defined in its Quality Assurance Plan (DNT 1995), which implements requirements of the LLNL Quality Assurance Program (LLNL 1996). The DNT program meets the requirements of DOE Order 5700.6C (as well as DOE O 414.1A). 
The following facility-specific QA plans apply to N Program work at NTS facilities:

- The DAF Quality Management Plan (DAF 1998) governs quality assurance of work performed at the DAF.

- When operational, the JASPER gas gun facility will have a dedicated quality assurance plan.

- The NTO QA Plan (NTO 2000) governs other LLNL facilities and general operations.

\subsection{Assessments}

DNT has established an ES\&H Self-Assessment Plan (DNT 1996b) to ensure compliance with ES\&H requirements and QA goals. This plan applies to the activities, facilities, and personnel that are associated with $\mathrm{N}$ Program work. It defines responsibilities, requirements, and processes associated with DNT assessments. It (the SA.6 revision) contains the schedule of assessments for NTO activities for the calendar years 2000 and 2001. The program uses three type of processes:

- $\quad$ Surveys are scheduled, topical or general system and/or activity reviews.

- Inspections are scheduled facility evaluations that provide formal comprehensive evaluations of compliance to codes, standards, and regulations.

- $\underline{\text { Audits }}$ are formal reviews of project or organization ES\&H and/or QA activities.

Formal documentation of the process and results of each assessment action are required.

For work at the NTS, the following documents establish assessment requirements:

- The general work of the NTO is assessed in accordance with the NTO SelfAssessment Program (NTO 2000).

- For operations at the DAF, two procedures define assessment requirements: Independent Assessments and Management Self-Assessments (DAF 1996b, c).

\subsection{Performance Evaluations}

An important aspect of the continuous improvement process is the feedback on performance that is provided by the responsible agent (customer) to the source or performing agency. N Program accomplishes this through the following mechanisms: 
- Contributes input to the annual performance appraisals of LLNL payroll employees who support the program.

- Contributes input to DOE/NV for the periodic evaluations of BN.

These submittals include feedback on how effectively ES\&H considerations were incorporated into the performance of work.

\subsection{Lessons Learned}

The lessons learned process for N Program activities at the NTS is established in the NTO Lessons Learned Procedure (NTO 2000). This procedure establishes a process for:

- Collecting lessons learned that evolve from N Program activities at the NTS.

- Distributing generated lessons learned to the N Program community, as well as to outside lessons learned collection sites that are maintained by DTED, LLNL, and DOE/NV.

- Distributing appropriate lessons learned that originate at outside sources to the N Program community.

NTO maintains records of lessons learned for a minimum of two years. N Program funds this process.

\subsection{Configuration Management}

To perform work safely, the configuration of the components of an activity must be consistent with that which was represented in the planning and evaluation phase of the activity. The components of concern generally fall into the following categories:

- Work controls that are established in operations documents, such as OSPs, FSPs, and execution plans.

- Design or physical features of a facility or piece of equipment. Examples could include the design or condition of a load-bearing member in a critical load path, or the physical make-up or condition of a relevant engineered safety feature (such as an interlock) in a facility.

For N Program, configuration management is maintained at the project or facility level. Line managers are responsible for assuring that they maintain control of the configuration of those components that have a bearing on the safe and successful execution of the activity. The application of a graded approach to configuration management is encouraged. 
Configuration management entails two elements. The first is to establish a configuration that is adequate for its intended purpose. This is accomplished through the engineering processes of design, development, and testing that are brought to bear on the activity. The configuration of a component is formally established by the review and approval processes that are imposed on N Program work by the Engineering Directorate. The second element is change control. The process for allowing a change to an approved component must be applied such that any impact of the change on the safe or successful performance of the component is evaluated and understood by the responsible individual(s). The change may only be adopted if it is reviewed and approved for implementation through a process that is comparable to the process that originally approved the component. Again, N Program depends on the line managers and subject matter experts of the Engineering Directorate for the successful implementation of this process. A formal configuration management process is in place at the DAF, defined in Configuration Management Plan (DAF 1996a). 


\section{References}

(DAF 1996a). Configuration Management Plan. Device Assembly Facility, Nevada Test Site, NV, DAF-PLN-MG-10, Rev. 0 (April 25, 1996).

(DAF 1996b). Independent Assessments. Device Assembly Facility, Nevada Test Site, NV, DAF-PRC-AD-08, Rev. 0 (September 13, 1996).

(DAF 1996c). Management Self-Assessments. Device Assembly Facility, Nevada Test Site, NV, DAF-PRC-AD-07, Rev. 0 (September 13, 1996).

(DAF 1998). Quality Management Plan. Device Assembly Facility, Nevada Test Site, NV, DAF-PLN-MG-05, Rev. 1 (October 15, 1998).

(DNT 1995). Quality Assurance Plan. Defense and Nuclear Technologies Directorate, Lawrence Livermore National Laboratory, Livermore, CA, DNT-QA.0 (February 1995).

(DNT 1999a). Environmental, Safety, and Health Self-Assessment Plan. Defense and Nuclear Technologies Directorate, Lawrence Livermore National Laboratory, Livermore, CA, DNT-SA.5 (June 1999).

(DNT 1999b). Integrated Safety Management Implementation Plan. Defense and Nuclear Technologies Directorate, Lawrence Livermore National Laboratory, Livermore, CA, DNT-ISMP.0 (October 1999).

(DOE 1990). U. S. Department of Energy Management Agreement between the Nevada Operations Office and the San Francisco Operations Office. Approved by D. W. Pearman, DOE/SAN, and N. C. Aquilina, DOE/NV (August 3, 1990).

(DOE 1996). Performance Based Management Contract for Management and Operating Support for the Nevada Operations Office, Contract DE-AC08-96NV11718 between the U.S. Department of Energy/Nevada Operations Office and Bechtel Nevada Corporation, Section H.24 (January 1, 1996).

(DOE 1999a). Activity Agreement for the Big Explosives Experimental Facility, Area 4, Nevada Test Site. Approved by G. W. Johnson, DOE/NV; M. R. Anastasio, LLNL; J. T. Mitchell, BN; and W. N. Ferguson, WSI (January 5, 1999).

(DOE 1999b). Activity Agreement for the Device Assembly Facility, Area 6, Nevada Test Site. Approved by G. W. Johnson, DOE/NV; S. M. Younger, LANL; M. R. Anastasio, LLNL; J. T. Mitchell, BN; and W. N. Ferguson, WSI (January 5, 1999). 
(DOE 1999c). Activity Agreement for the Ula Complex, Area 1, Nevada Test Site. Approved by G. W. Johnson, DOE/NV; S. M. Younger, LANL; M. R. Anastasio, LLNL; J. T. Mitchell, BN; and W. N. Ferguson, WSI (January 5, 1999).

(DOE 1999d). Device Assembly Facility (DAF) and Big Explosive Experimental Facility (BEEF): Delegation of Designated Official (DO) for DOE Nevada Operations Office (DOE/NV) Contract No. DE-AC08-96NV11718 with Bechtel Nevada Corporation $(B N)$. Memorandum from K. W. Powers, Contracting Officer to C. B. Tarter, LLNL Director (June 3, 1999).

(DOE 1999e). Device Assembly Facility (DAF), Big Explosive Experimental Facility (BEEF), and Ula Experiment Specific Activities: Delegation of Contracting Officer's Representative (COR) for DOE Nevada Operations Office (DOE/NV) Contract No. DE-AC08-98NV13149 with Wackenhut Services, Inc. (WSI). Memorandum from K. W. Powers, Contracting Officer, to C. B. Tarter, LLNL Director (June 3, 1999).

(DOE 1999f). DOE Nevada Operations Office (DOE/NV) Requirements for Lawrence Livermore National Laboratory (LLNL) Employees Working at DOE/NV Facilities. Memorandum from K. A. Carlson, DOE/NV Manager, to C. B. Tarter, LLNL Director (December 2, 1999).

(DOE 1999g). Real Estate/ Operations Permit. U. S. Department of Energy, Nevada Operations Office, Las Vegas, NV, NV M 412.X1 (December 15, 1999).

(DOE 1999h). Safety Management System Policy. U. S. Department of Energy, Nevada Operations Office, Las Vegas, NV, NV P 450.4A (December 15, 1999).

(DOE 1999i). Test Readiness: Delegation of Designated Official (DO) for DOE Nevada Operations Office (DOE/NV) Contract No. DE-AC08-96NV11718 with Bechtel Nevada Corporation $(B N)$. Memorandum from K. W. Powers, Contracting Officer, to C. B. Tarter, LLNL Director (June 3, 1999).

(ENG 1993a). Defense Sciences Engineering Division Quality Management Plan. Lawrence Livermore National Laboratory, Livermore, CA, DSED 93-08-11 (August 1993).

(ENG 1993b). Mechanical Engineering Design Safety Standards. Lawrence Livermore National Laboratory, Livermore, CA, M-012, Rev. 7A (February 1993).

(ENG 1997). Mechanical Engineering Policies and Procedures. Lawrence Livermore National Laboratory, Livermore, CA, UCRL-MA-123471 (January 2, 1997 revision).

(ENG 2000). The Engineering Policies, Procedures, and Practices Manual. Lawrence Livermore National Laboratory, Livermore, CA (January 2000). 
(LLNL 1996). Quality Assurance Program. Lawrence Livermore National Laboratory, Livermore, CA, M-078, Rev. 3 (July 1996).

(LLNL 1999). Integrated Safety Management System Description. Lawrence Livermore National Laboratory, Livermore, CA, UCRL-AR-132791, Version 2 (October 1, 1999).

(LLNL 2000). Environment, Safety, and Health Manual. Lawrence Livermore National Laboratory, Livermore, CA, UCRL-MA-133867 (updated continuously).

(N-Prog 1997). Nevada Experiments and Operations (N Program) Training and Qualifications Plan. N Program, Lawrence Livermore National Laboratory, Livermore, CA, N-PROG.PPP-001 (June 20, 1997).

(NTO 2000). Nuclear Test Operations Administration Plans and Procedures Manual. Nuclear Test Operations, Nevada Test Site, NV (updated continuously).

- “LLNL-NTO Lessons Learned,” NTO-ADM-105.

- “LLNL-NTO Quality Assurance Plan,” NTO-ADM-100.

- “LLNL-NTO Self-Assessment Program,” NTO-ADM-103.

- “LLNL-NTO Training and Qualifications," NTO-ADM-109. 



\section{Attachment 1. N Program ISM Requirements Matrix}


N Program Integrated Safety Management Reqiurements Matrix 2/22/00

\begin{tabular}{|c|c|c|c|c|c|c|}
\hline & $\mathrm{A}$ & $\mathrm{B}$ & $\mathrm{C}$ & $\mathrm{D}$ & $\mathrm{E}$ & $\mathrm{F}$ \\
\hline 1 & & & & & & \\
\hline & & & N Program & Integrated Safety Managem & nent Requirements Matrix & \\
\hline 14 & & DNT Directorate Documents & Institutional Source Documents & Responsible Positions & $\begin{array}{c}{ }^{* *} \text { Italics indicate an observation or comment, not a task } \\
\text { to be accomplished. }\end{array}$ & \\
\hline 15 & & FSP - Facility Safety Plans & ES\&HM - ES\&H Manual & PAY - Payroll management chain & N Program Documents & \\
\hline$\frac{16}{17}$ & & DQAP - DNT Quality Assurance Plan & TPM - Training Program Manual & FMC - Facility management chain & ADM-100, Quality Assurance Program & \\
\hline$\frac{17}{18}$ & & DSAP - DNT Self-Assessment Plan & ORIP - Occurrence Reporting & $\mathrm{AD}$ - Associate Director & ADM-103, Self-Assessment Program & \\
\hline 19 & & FISMSP - Facility ISMS Plans & & PL - Program Leader & ADM-104, Deficiency Cause and Trend Analysis & \\
\hline 20 & & FSAR - Facility Safety Analysis Reports & & RI - Responsible Individual & ADM-105, Lessons Learned & \\
\hline 21 & & FAA - Facility Authorization Agreements & & AM - Assurance Manager & ADM-109, LLNL-NTO Training and Qualifications & \\
\hline 22 & & FTSR - Facility TSRS & & FM - Facility Manager & NTS-101, Environment, Safety \& Health Policy & \\
\hline 23 & & FOSR - Facility OSRs & & IW - Individual Worker & NTS-102, Environment, Safety \& Health at the NTS & \\
\hline 24 & & ORP - DNT Occurrence Reporting Protocol & & & NTS-104, Occurrence Reporting System & \\
\hline 25 & & & & & NTS-107, Work Authorization and Risk Assessment & \\
\hline 26 & & & & & NTS-109, Stop Work & \\
\hline 27 & & & & & $\begin{array}{l}\text { NTS-301, Medical Surveillance of Occupational Injuries } \\
\text { and Illnesses }\end{array}$ & \\
\hline 28 & & & & & NPMP - N Program Managermrnt Plan & \\
\hline 29 & Ref. & $\begin{array}{l}\text { Requirements from the } \\
\text { LLNL ISMS Description }\end{array}$ & $\begin{array}{l}\text { LLNL Implementing Procedures \& } \\
\text { Documents }\end{array}$ & $\begin{array}{l}\text { Directorate Implementing Procedures } \\
\text { \& Documents }\end{array}$ & N Program Implementation Requirements & Responsible Positions \\
\hline $\begin{array}{ll}30 \\
31\end{array}$ & $\begin{array}{l}.2 \\
6.21\end{array}$ & $\begin{array}{l}\text { Roles and Responsibilities } \\
\text { LLNL Fundamental Guiding Principle }\end{array}$ & & & & \\
\hline 32 & 6.2 .1 & $\begin{array}{l}\text { LLNL Fundamental Guiding Principle } \\
\text { Each worker, supervisor, and manager is directly } \\
\text { responsible for ensuring their own safety and promoting a } \\
\text { safe, healthful, and environmentally sound workplace and } \\
\text { community. }\end{array}$ & & & & \\
\hline 33 & 6.2 .1 .1 & Accountability Policy & & & & \\
\hline 34 & $(1)$ & $\begin{array}{l}\text { The Laboratory's goal, simply, is to practice safety by taking } \\
\text { actions to avoid the potential for injury to people or damage } \\
\text { to property. The principal means of establishing and } \\
\text { enforcing accountability for ES\&H are: a) communicating } \\
\text { ES\&H expectations to employees; b) reinforcing } \\
\text { expectations through timely verbal feedback; ;) formal } \\
\text { appraisal and salary actions implemented annually for each } \\
\text { employee (see } 6.2 .2 .1) \text {; d) awards and recognition for } \\
\text { notable contributions to ES\&H; and e) corrective action in } \\
\text { cases of employee misconduct. Corrective action policies } \\
\text { and procedures are contained in the Laboratory's Personnel } \\
\text { Policy and Procedures Manual, Section E, II Corrective } \\
\text { Action. }\end{array}$ & \begin{tabular}{|l|} 
- Chapter 1, Section 1.2.2 \\
- Chapter 2, Appendix 2-H \\
"Accountability Requirements". \\
- Chapter 2, Appendix 2-I "Impact of \\
Safety Performance on Appraisals and \\
Ranking" \\
- Personnel Policy and Procedures \\
Manual, Section E, II, Corrective Action
\end{tabular} & $\begin{array}{l}\text { DNT implements these requirements } \\
\text { directly from the ES\&H Manual and } \\
\text { Personnel Policy and Procedures } \\
\text { Manual. Institutional appraisal and salary } \\
\text { guidelines are implemented annually by } \\
\text { memoranda. }\end{array}$ & \begin{tabular}{|l|} 
Program implements these requirements through \\
referenced DNT processes \\
procedures and relevant N Program \\
implemented through the Engineering ISMS IP.
\end{tabular} & PAY,FMC,PMC \\
\hline 35 & (2) & $\begin{array}{l}\text { Each employee is directly responsible for ensuring his or } \\
\text { her own safety and the safety of others that could be } \\
\text { impacted by their actions. All members of the workforce are } \\
\text { held accountable for meeting the Laboratory's ES\&H } \\
\text { requirements as defined in this Description and the Work } \\
\text { Smart Standards set in Contract 48, and as detailed in the } \\
\text { LLNL ES\&H Manual and other approved manuals, plans, } \\
\text { and procedures. }\end{array}$ & $\begin{array}{l}\text { - Chapter 2, Appendix 2-H } \\
\text { "Accountability Requirements". } \\
\text { - Chapter 1, Section } 1.2 .3 \text { and } 1.3\end{array}$ & $\begin{array}{l}\text { DNT implements these requirements } \\
\text { through the DNT ISMS Implementation } \\
\text { Plan, the DNT ES\&H Policy and } \\
\text { individual FSPs, OSPs and IWSs. }\end{array}$ & $\begin{array}{l}\text { N Program implements these requirements through } \\
\text { referenced DNT processes } \\
\text { procedures and the NPMP. }\end{array}$ & PAY,FMC,PMC,IW \\
\hline
\end{tabular}


N Program Integrated Safety Management Reqiurements Matrix 2/22/00

\begin{tabular}{|c|c|c|c|c|c|c|}
\hline & A & $\mathrm{B}$ & $\mathrm{C}$ & $\mathrm{D}$ & $\mathrm{E}$ & $\mathrm{F}$ \\
\hline 29 & Ref. & $\begin{array}{l}\text { Requirements from the } \\
\text { LLNL ISMS Description }\end{array}$ & $\begin{array}{l}\text { LLNL Implementing Procedures \& } \\
\text { Documents }\end{array}$ & $\begin{array}{l}\text { Directorate Implementing Procedures } \\
\text { \& Documents }\end{array}$ & N Program Implementation Requirements & Responsible Positions \\
\hline 36 & $\overline{(3)}$ & \begin{tabular}{|l|} 
Accountability applies to all levels of employees including \\
managers and supervisors and contains positive \\
reinforcement for meeting Laboratory safety expectations \\
and negative consequences for failing to do so. The \\
management of each Directorate is responsible for having in \\
place effective processes to implement, measure, and \\
reinforce Laboratory safety expectations. Each Directorate \\
is to use its Directorate awards and recognition program to \\
promote exemplary safety behavior and performance.
\end{tabular} & $\begin{array}{l}\text { - Chapter 2, Appendix 2-H } \\
\text { "Accountability Requirements" }\end{array}$ & \begin{tabular}{|l|} 
DNT implements these requirements \\
directly from the ES\&H and HR Manuals, \\
and is an element of the DSAP. DNT has \\
implemented the Directorate Awards \\
Program and specifically identified safety \\
performance as an element in this \\
process.
\end{tabular} & $\begin{array}{l}\text { N Program implements these requirements through } \\
\text { referenced DNT processes. Relevant Payroll actions } \\
\text { are implemented through the Engineering ISMS IP. }\end{array}$ & PAY, FMC, PMC \\
\hline 37 & $(4)$ & $\begin{array}{l}\text { Each Directorate will hold its employees accountable for } \\
\text { compliance with Laboratory ES\&H requirements through } \\
\text { personnel processes such as performance appraisals, } \\
\text { ranking, salary management actions, awards and } \\
\text { recognition, and the application of corrective action. In } \\
\text { addition: } \\
\text { a) Each worker, immediate supervisor, and manager is } \\
\text { directly responsible for ensuring accidents and injuries are } \\
\text { properly reported. Accurate and complete reporting is } \\
\text { necessary. } \\
\text { b) All employees are responsible for bringing safety } \\
\text { concerns promptly to the attention of the appropriate } \\
\text { manager or supervisor for resolution. If a satisfactory } \\
\text { response is not received then the senior manager for the } \\
\text { organization should be contacted and then the Laboratory } \\
\text { Site Manager. }\end{array}$ & $\begin{array}{l}\text { - Chapter 2, Section } 2.2 .4 \text { and } \\
\text { - Chapter } 1 \text {, Sections } 1.3 \text { and } 1.8 .2\end{array}$ & $\begin{array}{l}\text { DNT implements these requirements } \\
\text { through the DNT ISMS Implementation } \\
\text { Plan, individual FSPs, and the ORP. }\end{array}$ & \begin{tabular}{|l|} 
N Program implements these requirements through \\
referenced DNT processes \\
procedures and relevent N Program \\
implemented through the Engineering ISMS IP.
\end{tabular} & PAY, FMC, PMC, IW \\
\hline 38 & (5) & $\begin{array}{l}\text { Feedback and corrective action will be taken consistent with } \\
\text { Laboratory Personnel Polices and Procedures for violations } \\
\text { of Laboratory ES\&H requirements. Feedback may be } \\
\text { verbal or written. Corrective actions may include the } \\
\text { following depending on the nature and severity of the } \\
\text { violation: written warning, suspension without pay, } \\
\text { permanent or temporary salary reduction, demotion, and } \\
\text { dismissal. Corrective actions must be coordinated through } \\
\text { the Office of Staff Relations to assure uniform application } \\
\text { within the Laboratory. }\end{array}$ & \begin{tabular}{|l|} 
- Chapter 2, Appendix 2-H \\
"Accountability Requirements" \\
- Personnel Policy and Procedures \\
Manual, Section E, II, Corrective Action
\end{tabular} & $\begin{array}{l}\text { DNT implements these requirements } \\
\text { through the DNT ISMS Implementation } \\
\text { Plan and the Personnel Policy and } \\
\text { Procedures Manual. }\end{array}$ & $\begin{array}{l}\text { N Program implements these requirements through } \\
\text { referenced DNT processes, and relevant N Program } \\
\text { procedures. Relevant payroll actions are implemented } \\
\text { through the Engineering ISMS IP. }\end{array}$ & PAY \\
\hline 39 & $(6)$ & $\begin{array}{l}\text { Each payroll Directorate is to maintain records of all safety } \\
\text { awards and corrective actions it administers. A summary of } \\
\text { these records is to be reported to the DDO no later than one } \\
\text { month after the end of each fiscal year, starting in the year } \\
2000 \text {. The DDO is to compile these reports into a } \\
\text { Laboratory summary for management information and use. }\end{array}$ & $\begin{array}{l}\text { Institutional Gap-No specific } \\
\text { implementation requirements have } \\
\text { been developed. }\end{array}$ & $\begin{array}{l}\text { DNT will implement this requirement once } \\
\text { institutional requirements and procedures } \\
\text { are approved. }\end{array}$ & Will be determined when DNT fills the Gap. & PAY \\
\hline 40 & $\overline{(7)}$ & $\begin{array}{l}\text { When an incident or a systemic failure occurs that affects } \\
\text { worker safety, the environment, or public health, the } \\
\text { organization authorizing the work is responsible for ensuring } \\
\text { an investigation of the relevant circumstances or assisting } \\
\text { DOE investigators in conducting a review that falls within } \\
\text { their purview. Necessary changes are to be made to the } \\
\text { relevant policies, procedures, and/or hardware based on the } \\
\text { findings of the review by the responsible organization. }\end{array}$ & $\begin{array}{l}\text { - Chapter 2, Section 2.2.4; } \\
\text { - Chapter 1, Sections 1.3.2; } \\
\text { - Chapter 4; } \\
\text { - Supplement 4.08; and the } \\
\text { - LLNL Implementing Procedure for } \\
\text { DOE order 232.1 A }\end{array}$ & $\begin{array}{l}\text { DNT implements these requirements } \\
\text { through the DNT ISMS Implementation } \\
\text { Plan and the ORP. }\end{array}$ & $\begin{array}{l}\text { N Program implements these requirements through } \\
\text { referenced DNT processes*, and relevant N Program } \\
\text { Procedures. }\end{array}$ & PAY, FMC, PMC \\
\hline
\end{tabular}


N Program Integrated Safety Management Reqiurements Matrix 2/22/00

\begin{tabular}{|c|c|c|c|c|c|c|}
\hline & A & $\mathrm{B}$ & $\mathrm{C}$ & $\mathrm{D}$ & $\mathrm{E}$ & $\mathrm{F}$ \\
\hline 29 & Ref. & $\begin{array}{l}\text { Requirements from the } \\
\text { LLNL ISMS Description }\end{array}$ & $\begin{array}{l}\text { LLNL Implementing Procedures \& } \\
\text { Documents }\end{array}$ & \begin{tabular}{|c|} 
Directorate Implementing Procedures \\
\& Documents
\end{tabular} & N Program Implementation Requirements & Responsible Positions \\
\hline 41 & 6.2.2 & $\begin{array}{l}\text { Guiding Principle } 1 \text { - Line Management Responsibility } \\
\text { for Safety } \\
\text { Line management is responsible for the safety system and } \\
\text { is ultimately responsible for the safety at the Laboratory. }\end{array}$ & & & & \\
\hline 43 & 6.2.2.1 & $\begin{array}{l}\text { Safety Performance Directly Affects Appraisals and } \\
\text { Salary Actions }\end{array}$ & & & & \\
\hline 44 & (1) & $\begin{array}{l}\text { Safety expectations are to be established for each } \\
\text { employee, including supervisors and managers. } \\
\text { Expectations are to be documented and communicated and } \\
\text { the employee given the opportunity to provide feedback. }\end{array}$ & $\begin{array}{l}\text { - Chapter 2, Appendix 2-I "Impact of } \\
\text { Safety Performance on Appraisals and } \\
\text { Ranking" }\end{array}$ & $\begin{array}{l}\text { DNT implements these requirements } \\
\text { through the DNT ISMS Implementation } \\
\text { Plan and annual performance appraisal } \\
\text { guidelines. }\end{array}$ & $\begin{array}{l}\text { N Program implements these requirements through } \\
\text { referenced DNT processes*, and relevant N Program } \\
\text { Procedures. Relevant Payroll actions are implemented } \\
\text { through the Engineering ISMS IP. }\end{array}$ & PAY, FMC, PMC \\
\hline 45 & (2) & \begin{tabular}{|l|} 
A substantive assessment of safety performance is to be \\
included in each individual's performance appraisal, \\
addressing expectations and accomplishments. For \\
managers and supervisors, the appraisal is also to address \\
performance in establishing and implementing safety \\
processes.
\end{tabular} & $\begin{array}{l}\text { - Chapter 2, Appendix 2-I "Impact of } \\
\text { Safety Performance on Appraisals and } \\
\text { Ranking" }\end{array}$ & $\begin{array}{l}\text { DNT implements these requirements } \\
\text { through the DNT ISMS Implementation } \\
\text { Plan and annual performance appraisal } \\
\text { guidelines. }\end{array}$ & $\begin{array}{l}\text { N Program implements these requirements through } \\
\text { referenced DNT processes*. Relevant payroll actions } \\
\text { are implemented through the Engineering ISMS IP. }\end{array}$ & PAY \\
\hline 46 & (3) & $\begin{array}{l}\text { Safety responsibilities and safety performance are to be } \\
\text { explicit considerations during the annual ranking process } \\
\text { and important factors in determining salary actions and } \\
\text { promotions. }\end{array}$ & $\begin{array}{l}- \text { Chapter 2, Appendix 2-I "Impact of } \\
\text { Safety Performance on Appraisals and } \\
\text { Ranking" }\end{array}$ & $\begin{array}{l}\text { DNT implements these requirements } \\
\text { through the DNT ISMS Implementation } \\
\text { Plan and annual performance appraisal } \\
\text { guidelines. }\end{array}$ & $\begin{array}{l}\text { N Program implements these requirements through } \\
\text { referenced DNT processes. Relevant Payroll actions } \\
\text { are implemented through the Engineering ISMS IP. }\end{array}$ & PAY \\
\hline 47 & 6.2.3 & $\begin{array}{l}\text { DOE Guiding Principle } 2 \text { - Clear Roles and } \\
\text { Responsibilities } \\
\text { Clear roles and responsibilities are established and } \\
\text { maintained. }\end{array}$ & & & & \\
\hline 49 & 6.2.3.1 & $\begin{array}{l}\text { Safety Roles, Responsibilities, and Authorities (RRAs) } \\
\text { for Organizations and Individuals Are Clearly Defined }\end{array}$ & & & & \\
\hline 50 & (1) & $\begin{array}{l}\text { The program organization is responsible for authorizing } \\
\text { work. Program organizations are distinguished by having } \\
\text { control of the funding as well as the responsibility to the } \\
\text { sponsor for accomplishing the programmatic mission or } \\
\text { activity. }\end{array}$ & - Chapter 1 , Sections 1.3 .4 and 1.4 & $\begin{array}{l}\text { DNT implements these requirements } \\
\text { through the DNT ISMS Implementation } \\
\text { Plan and FSPs, OSPs and IWSs. }\end{array}$ & $\begin{array}{l}\text { N Program implements these requirements through } \\
\text { referenced DNT processes*, and relevant N Program } \\
\text { procedures and the NPMP. }\end{array}$ & PMC \\
\hline 51 & (2) & $\begin{array}{l}\text { The responsibility for work authorization may be delegated } \\
\text { to another organization along with the funds to accomplish a } \\
\text { specific work element. All delegations of work authorization } \\
\text { responsibility must be formally documented and approved } \\
\text { by the management of each Directorate involved. } \\
\text { Irrespective of the number or level of work authorization } \\
\text { delegations, the program organization retains ultimate } \\
\text { responsibility back to the sponsor for the conduct of the } \\
\text { work. }\end{array}$ & - Chapter 1 , Sections 1.4 and 1.4 .2 & $\begin{array}{l}\text { DNT implements these requirements } \\
\text { through the DNT ISMS Implementation } \\
\text { Plan and by invoking institutionally } \\
\text { developed MOUs with other } \\
\text { organizations. }\end{array}$ & $\begin{array}{l}\text { N Program implements these requirements through } \\
\text { referenced DNT processes }{ }^{*} \text {, and relevant N Program } \\
\text { procedures and the NPMP. }\end{array}$ & FMC, PMC \\
\hline 52 & (3) & $\begin{array}{l}\text { Work performed as services by one organization for another } \\
\text { is an area of particular concern requiring special attention. } \\
\text { The appropriate division of safety RRAs between the } \\
\text { requesting and the services organizations, based on the } \\
\text { type of services, is specifically addressed in the ES\&H } \\
\text { Manual. }\end{array}$ & - Chapter 1 , Sections 1.4 and 1.4 .3 & $\begin{array}{l}\text { DNT implements these requirements } \\
\text { directly from the ES\&H Manual and } \\
\text { through the DNT ISMS Implementation } \\
\text { Plan. }\end{array}$ & $\begin{array}{l}\text { N Program implements these requirements through } \\
\text { referenced DNT processes* }{ }^{*} \text {, and the NPMP. }\end{array}$ & PAY, FMC, PMC \\
\hline 53 & (4) & $\begin{array}{l}\text { The organization authorizing work is responsible for the } \\
\text { activity's conduct, including accomplishing the technical } \\
\text { objectives and safety requirements within the defined } \\
\text { budget. The individuals responsible for: }\end{array}$ & - Chapter 1 , Sections 1.3 .4 and 1.4 & N/A & N/A & \\
\hline 54 & (a) & authorizing the work activity; & - Chapter 1 , Sections 1.3 .4 and 1.4 & $\begin{array}{l}\text { DNT implements these requirements } \\
\text { through the DNT ISMS Implementation } \\
\text { Plan, FSPs, OSPS, and IWSs. }\end{array}$ & $\begin{array}{l}\text { N Program implements these requirements through } \\
\text { referenced DNT processes", the NPMP, and the OSPs } \\
\text { and FSPS. }\end{array}$ & FMC, PMC \\
\hline 55 & (b) & $\begin{array}{l}\text { validating that the proposed work falls within the established } \\
\text { safety envelope(s) (i.e., facility and/or operational } \\
\text { concurrence); }\end{array}$ & $\begin{array}{l}\cdot \text { Chapter } 1 \text {, Sections } 1.3 .4,1.3 .8, \text { and } \\
1.4\end{array}$ & $\begin{array}{l}\text { DNT implements these requirements } \\
\text { through the DNT ISMS Implementation } \\
\text { Plan, FSPs, OSPS, and IWSs. }\end{array}$ & $\begin{array}{l}\text { N Program implements these requirements through } \\
\text { referenced DNT processes*, relevant N Program } \\
\text { procedures, the NPMP, and the OSPS and FSPS. }\end{array}$ & FMC, PMC \\
\hline
\end{tabular}

* "Referenced DNT processes" are identified in the companion DNT column entitled "Directorate Implementing Procedures and Documents" 
N Program Integrated Safety Management Reqiurements Matrix 2/22/00

\begin{tabular}{|c|c|c|c|c|c|c|}
\hline & $\mathrm{A}$ & $\mathrm{B}$ & $\mathrm{C}$ & $\mathrm{D}$ & $\mathrm{E}$ & $\mathrm{F}$ \\
\hline 29 & Ref. & $\begin{array}{l}\text { Requirements from the } \\
\text { LLNL ISMS Description }\end{array}$ & $\begin{array}{l}\text { LLNL Implementing Procedures \& } \\
\text { Documents }\end{array}$ & $\begin{array}{c}\text { Directorate Implementing Procedures } \\
\text { \& Documents }\end{array}$ & N Program Implementation Requirements & Responsible Positions \\
\hline 56 & (c) & $\begin{array}{l}\text { supervising the specific work (i.e., ensuring work } \\
\text { requirements are met) must be clearly identified and their } \\
\text { safety RRAs clearly defined. }\end{array}$ & - Chapter 1, Section 1.3.4 & $\begin{array}{l}\text { DNT implements these requirements } \\
\text { through the DNT ISMS Implementation } \\
\text { Plan, FSPs, OSPs, and IWSs. }\end{array}$ & $\begin{array}{l}\text { N Program implements these requirements through } \\
\text { referenced DNT processes } \\
\text { procedures, the NPMP, and the OSPS N and FSPs. }\end{array}$ & PAY, FMC, PMC \\
\hline 57 & (5) & $\begin{array}{l}\text { The individual supervising work is responsible for identifying } \\
\text { the organizational positions associated with the work activity } \\
\text { and the corresponding safety RRAs. The requirement for } \\
\text { safety RRAs may be satisfied by one or more of the } \\
\text { following: a) referencing a position-specific ES\&H } \\
\text { responsibility statement in the Directorate Implementation } \\
\text { Plan and any succeeding documentation; b) listing the } \\
\text { ES\&H responsibilities assigned to the position as delineated } \\
\text { in ES\&H documents (e.g., ES\&H Manual, FSPs, OSPs, } \\
\text { etc.); or c) using an equivalent approach defined in the } \\
\text { Directorate Implementation Plan and any succeeding } \\
\text { documentation. }\end{array}$ & - Chapter 1, Section 1.3.5 & $\begin{array}{l}\text { DNT implements these requirements in } \\
\text { Section } 3 \text { of the DNT ISMS } \\
\text { Implementation Plan, individual FSPs, } \\
\text { FISMSPs, OSPs and IWSs. }\end{array}$ & $\begin{array}{l}\text { N Program implements these requirements through } \\
\text { referenced DNT processes*, relevant N Program } \\
\text { procedures, the NPMP, and the OSPs and FSPs. }\end{array}$ & RI \\
\hline 58 & $(6)$ & $\begin{array}{l}\text { The position-specific safety RRA information is to be } \\
\text { provided to the individual performing the work and be } \\
\text { readily accessible to others as described in the Directorate } \\
\text { Implementation Plan and any succeeding documentation. }\end{array}$ & - Chapter 1, Section 1.3.5 & \begin{tabular}{|l|} 
DNT implements these requirements \\
through the DNT ISMS Implementation \\
Plan, FSPs, FISMSPs, OSPs, and IWSs.
\end{tabular} & $\begin{array}{l}\text { N Program implements these requirements through } \\
\text { referenced DNT processes } \\
\text { procedures, the NPMP, and the OSPant N Program } \\
\text { pand FSPs. }\end{array}$ & $\mathrm{RI}, \mathrm{IW}$ \\
\hline 59 & (7) & $\begin{array}{l}\text { To ensure that facilities are properly managed, coordinated, } \\
\text { and conducted, each Facility AD is responsible for } \\
\text { identifying a Facility Point Of Contact (FPOC) and an } \\
\text { alternate for each facility to fulfill responsibilities identified in } \\
\text { the ES\&H Manual. }\end{array}$ & - Chapter 1, Section 1.3.8 & $\begin{array}{l}\text { DNT implements these requirements } \\
\text { through the DNT ISMS Implementation } \\
\text { Plan and individual FSPs. }\end{array}$ & $\begin{array}{l}\text { N Program implements these requirements through } \\
\text { referenced DNT processes }{ }^{*} \text {, and OSPs and FSPs. }\end{array}$ & FMC, PMC \\
\hline 60 & $(8)$ & $\begin{array}{l}\text { Each Directorate is to have an Assurance Manager to } \\
\text { provide independent oversight of the Directorate's } \\
\text { organizations, facilities, and activities to assure the proper } \\
\text { implementation of the safety program. }\end{array}$ & - Chapter 1, Section 1.3.6 & $\begin{array}{l}\text { DNT implements these requirements } \\
\text { through the DNT ISMS Implementation } \\
\text { Plan. }\end{array}$ & $\begin{array}{l}\text { N Program implements these requirements through } \\
\text { referenced DNT processes. }{ }^{*}\end{array}$ & $A D$ \\
\hline 61 & (9) & $\begin{array}{l}\text { LLNL's ES\&H organizations are responsible for supporting } \\
\text { the management chain by participating in work activity } \\
\text { planning, monitoring operations for compliance, and } \\
\text { providing the information needed to the appropriate staff } \\
\text { and management to help maintain a safe work environment. }\end{array}$ & $\begin{array}{l}- \text { Chapter } 1 \text {, Sections } 1.3 .9,1.3 .10 \text { and } \\
\text { 1.3.11 }\end{array}$ & $\begin{array}{l}\text { DNT implements these requirements } \\
\text { through the DNT ISMS Implementation } \\
\text { Plan, FSPs, OSPs, IWSs and ES\&H } \\
\text { Team Action Plans. }\end{array}$ & 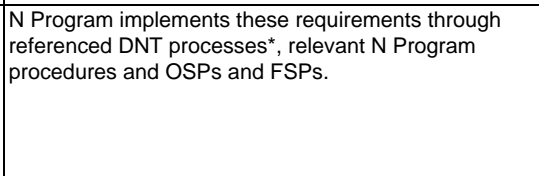 & PAY \\
\hline 62 & 6.2.3.2 & $\begin{array}{l}\text { The Management Chain Is Defined for Each Work } \\
\text { Activity }\end{array}$ & & & & \\
\hline 63 & (1) & $\begin{array}{l}\text { For each work activity, the individuals serving in the } \\
\text { management chain (i.e., first-level supervisor up to the } \\
\text { responsible Associate Director) are to be identified by the } \\
\text { organization authorizing the work. The management chain } \\
\text { has direct control over the funding for the work activity. } \\
\text { Figure } 6.2 \text { of the LLNL ISMS Description shows a basic } \\
\text { framework of the overall structure for the LLNL mixed matrix } \\
\text { organization in an extension and clarification of the } \\
\text { operational functions now comprised of Program, Payroll, } \\
\text { Facility, and Services. In this basic framework, the } \\
\text { management chain exists for all LLNL operations down a } \\
\text { clear line of funding and ES\&H responsibility both directly } \\
\text { and through formal Delegation and Acceptance } \\
\text { Agreements. Nominal and special case scenarios have } \\
\text { been demonstrated and Section } 8.4 \text { presents additional } \\
\text { information and four typical operational cases. Many } \\
\text { Associate Directors have all operational functions in their }\end{array}$ & - Chapter 1, Section 1.4 & $\begin{array}{l}\text { DNT implements these requirements } \\
\text { through the DNT ISMS Implementation } \\
\text { Plan, FSPs, OSPs, IWSs, and FISMSPs. }\end{array}$ & $\begin{array}{l}\text { N Program implements these requirements through } \\
\text { referenced DNT processes*, the NPMP and the OSPs } \\
\text { and FSPs. }\end{array}$ & PAY, FMC, PMC \\
\hline 64 & & $\begin{array}{l}\text { their people, the work, and the structure both up and down } \\
\text { as well across the structure }\end{array}$ & & & & \\
\hline
\end{tabular}

* "Referenced DNT processes" are identified in the companion DNT column entitled "Directorate Implementing Procedures and Documents" 
N Program Integrated Safety Management Reqiurements Matrix 2/22/00

\begin{tabular}{|c|c|c|c|c|c|c|}
\hline & A & $\mathrm{B}$ & $\mathrm{C}$ & $\mathrm{D}$ & $E$ & $\mathrm{~F}$ \\
\hline 29 & Ref. & $\begin{array}{l}\text { Requirements from the } \\
\text { LLNL ISMS Description }\end{array}$ & $\begin{array}{l}\text { LLNL Implementing Procedures \& } \\
\text { Documents }\end{array}$ & $\begin{array}{c}\text { Directorate Implementing Procedures } \\
\text { \& Documents }\end{array}$ & N Program Implementation Requirements & Responsible Positions \\
\hline 65 & $(2)$ & The management chain is responsible for: & $\mathrm{N} / \mathrm{A}$ & N/A & N/A & \\
\hline 66 & (a) & defining the scope of work; & - Chapter 1, Section 1.3.4 & $\begin{array}{l}\text { DNT implements these requirements } \\
\text { through the DNT ISMS Implementation } \\
\text { Plan, FSPs, OSPS, IWSs, and FISMSPs. }\end{array}$ & $\begin{array}{l}\text { N Program implements these requirements through } \\
\text { referenced DNT processes*, relevant N Program } \\
\text { procedures, the NPMP, and the OSPs and FSPs. }\end{array}$ & FMC, PMC \\
\hline 67 & (b) & $\begin{array}{l}\text { ensuring that the hazards control system is effectively } \\
\text { implemented; }\end{array}$ & $\begin{array}{l}\cdot \text { Chapter } 1 \text {, Sections 1.3.1, 1.3.4 and } \\
1.3 .5\end{array}$ & $\begin{array}{l}\text { DNT implements these requirements } \\
\text { through the DNT ISMS Implementation } \\
\text { Plan, FSPs, OSPs, IWSs, the DNT SA } \\
\text { Plan and FISMSPS. }\end{array}$ & $\begin{array}{l}\text { N Program implements these requirements through } \\
\text { referenced DNT processes*, relevant N Program } \\
\text { procedures, the NPMP, and the OSPs and FSPs. }\end{array}$ & FMC, PMC \\
\hline 68 & (c) & $\begin{array}{l}\text { ensuring that workers have the skills, knowledge, and } \\
\text { abilities (SKAs) to initially evaluate the hazards associated } \\
\text { with an activity; }\end{array}$ & $\begin{array}{l}\cdot \text { Chapter } 1 \text {, Sections 1.3.1, 1.3.4 and } \\
1.3 .5\end{array}$ & $\begin{array}{l}\text { DNT implements these requirements } \\
\text { through the DNT ISMS Implementation } \\
\text { Plan, FSPs, OSPs, IWSs, FISMSPs and } \\
\text { individual position descriptions. }\end{array}$ & $\begin{array}{l}\text { N Program implements these requirements through } \\
\text { referenced DNT processes*, relevant N Program } \\
\text { procedures, the NPMP, and the OSPs and FSPs. }\end{array}$ & PAY, FMC, PMC \\
\hline 69 & (d) & $\begin{array}{l}\text { ensuring that workers have the SKAs, including physical } \\
\text { capabilities, to perform the assigned work safely; }\end{array}$ & $\begin{array}{l}\text { - Chapter 1, Sections 1.3.1, 1.3.4, and } \\
\text { 1.3.5; } \\
\text { - Chapter 2, Section 2.2.4 } \\
\text { - Chapter 5, Sections 5.2.1 and 5.2.2 }\end{array}$ & $\begin{array}{l}\text { DNT implements these requirements } \\
\text { through the DNT ISMS Implementation } \\
\text { Plan, FSPs, OSPs, IWSs, FISMSPs and } \\
\text { individual position descriptions. }\end{array}$ & $\begin{array}{l}\text { N Program implements these requirements through } \\
\text { referenced DNT processes*, relevant N Program } \\
\text { procedures, the NPMP, and the OSPs and FSPs. }\end{array}$ & PAY, FMC, PMC \\
\hline 70 & (e) & $\begin{array}{l}\text { authorizing the defined work, subject to the appropriate } \\
\text { controls; }\end{array}$ & - Chapter 1, Sections 1.3 .4 and 1.3 .5 & $\begin{array}{l}\text { DNT implements these requirements } \\
\text { through the DNT ISMS Implementation } \\
\text { Plan, FSPs, OSPs, IWSs, and FISMSPs. }\end{array}$ & $\begin{array}{l}\text { N Program implements these requirements through } \\
\text { referenced DNT processes } \\
\text { procedures, the relevant N Program } \\
\text { pros and the OSPS and FSPs. }\end{array}$ & FMC, PMC \\
\hline 71 & (f) & $\begin{array}{l}\text { ensuring that the workers perform the work safely and in } \\
\text { conformance with applicable institutional, facility, and } \\
\text { activity controls; }\end{array}$ & $\begin{array}{l}\cdot \text { Chapter } 1 \text {, Sections 1.3.1. 1.3.4 and } \\
1.3 .5\end{array}$ & $\begin{array}{l}\text { DNT implements these requirements } \\
\text { through the DNT ISMS Implementation } \\
\text { Plan, FSPs, OSPs, IWSs, the DNT SA } \\
\text { Plan and FISMSPS. }\end{array}$ & $\begin{array}{l}\text { N Program implements these requirements through } \\
\text { referenced DNT processes*, relevant N Program } \\
\text { procedures, the NPMP, and the OSPs and FSPs. }\end{array}$ & PAY, FMC, PMC \\
\hline 72 & (g) & $\begin{array}{l}\text { monitoring and, as appropriate, strengthening the work } \\
\text { activity's safety performance; }\end{array}$ & $\begin{array}{l}\cdot \text { Chapter } 1 \text {, Sections 1.3.1. 1.3.4 and } \\
\text { 1.3.5 }\end{array}$ & $\begin{array}{l}\text { DNT implements these requirements } \\
\text { through the DNT ISMS Implementation } \\
\text { Plan, FSPs, OSPs, IWSs, and FISMSPs. }\end{array}$ & $\begin{array}{l}\text { N Program implements these requirements through } \\
\text { referenced DNT processes*, relevant N Program } \\
\text { procedures, the NPMP, and the OSPs and FSPs. }\end{array}$ & PAY, FMC, PMC \\
\hline 73 & (h) & soliciting worker input. & - Chapter 1 , Sections 1.3.4 & $\begin{array}{l}\text { DNT implements these requirements } \\
\text { through the DNT ISMS Implementation } \\
\text { Plan, FSPs, OSPs, IWSs and FISMSPs. }\end{array}$ & $\begin{array}{l}\text { N Program implements these requirements through } \\
\text { referenced DNT processes*, relevant N Program } \\
\text { procedures, the NPMP, and the OSPs and FSPs. }\end{array}$ & PAY, FMC, PMC \\
\hline 74 & 6.2 .3 .3 & $\begin{array}{l}\text { Processes for Case Management of "Lost and } \\
\text { Restricted Work Days" Are Defined }\end{array}$ & & & & \\
\hline 75 & (1) & $\begin{array}{l}\text { The objective of a case management program is to return } \\
\text { injured personnel to work as soon as reasonably possible } \\
\text { consistent with the individual's personal health and safety. }\end{array}$ & $\begin{array}{l}\cdot \text { Chapter 2, Appendix 2-F "Lost and } \\
\text { Restricted Work Day Case } \\
\text { Management" }\end{array}$ & $\begin{array}{l}\text { To Be Determined (TBD) by the } \\
\text { institution. The DNT Program will be } \\
\text { consistent with the Institutional Program. }\end{array}$ & $\begin{array}{l}\text { N Program implements these requirements through } \\
\text { referenced DNT processes*. Relevant Payroll actions } \\
\text { are implemented through the Engineering ISMS IP. }\end{array}$ & PAY \\
\hline 76 & (2) & $\begin{array}{l}\text { Each Associate Director is responsible for putting in place } \\
\text { within their organization a "lost and restricted work days" } \\
\text { case management program consistent with LLNL's } \\
\text { institutional case management program guidelines in the } \\
\text { ES\&H Manual. }\end{array}$ & $\begin{array}{l}\text { - Chapter 2, Appendix 2-F "Lost and } \\
\text { Restricted Work Day Case } \\
\text { Management" } \\
\text { - Chapter 1, Section 1.3.3 } \\
\text { - Chapter 5, Appendix D } \\
\end{array}$ & $\begin{array}{l}\text { To Be Determined (TBD) by the } \\
\text { institution. The DNT Program will be } \\
\text { consistent with the Institutional Program. }\end{array}$ & $\begin{array}{l}\text { N Program implements these requirements through } \\
\text { referenced DNT processes*. Relevant Payroll actions } \\
\text { are implemented through the Engineering ISMS IP. }\end{array}$ & PAY \\
\hline 77 & 6.2 .3 .4 & $\begin{array}{l}\text { LLNL's Commitment to Safety and ISM is Formally } \\
\text { Extended to Subcontractors and Subcontract } \\
\text { Employees }\end{array}$ & & & & \\
\hline 78 & (1) & $\begin{array}{l}\text { To ensure that the Laboratory's commitment to safety and } \\
\text { ISM is formally extended to its subcontractors, lower-tier } \\
\text { subcontractors, and their employees, safety requirements } \\
\text { are to be incorporated into the subcontracts and flowed } \\
\text { down to lower-tier subcontractor's as appropriate. }\end{array}$ & $\begin{array}{l}\text { - Chapter } 1 \text {, Section } 1.5 .2 \text { and } \\
\text { - Supplement } 1.11\end{array}$ & \begin{tabular}{|l} 
DNT follows LLNL's Procurement \\
Procedures regarding subcontractors.
\end{tabular} & $\begin{array}{l}\text { N Program implements these requirements through } \\
\text { referenced DNT processes* }\end{array}$ & PAY, FMC, PMC \\
\hline
\end{tabular}


N Program Integrated Safety Management Reqiurements Matrix 2/22/00

\begin{tabular}{|c|c|c|c|c|c|c|}
\hline & $\mathrm{A}$ & $\mathrm{B}$ & $\mathrm{C}$ & $\mathrm{D}$ & $\mathrm{E}$ & $\mathrm{F}$ \\
\hline 29 & Ref. & $\begin{array}{l}\text { Requirements from the } \\
\text { LLNL ISMS Description }\end{array}$ & $\begin{array}{l}\text { LLNL Implementing Procedures \& } \\
\text { Documents }\end{array}$ & \begin{tabular}{|c} 
Directorate Implementing Procedures \\
\& Documents
\end{tabular} & N Program Implementation Requirements & Responsible Positions \\
\hline 79 & $\overline{(2)}$ & $\begin{array}{l}\text { Selection of the appropriate safety requirements is to be } \\
\text { done through use of the provisions of Section } 7.3 \text { of the } \\
\text { LLNL ISMS Description with the Work Activity Authorization } \\
\text { Structure in Table } 7.2 \text { and the ES\&H Manual. These } \\
\text { provide a graded approach to the hazards of a planned } \\
\text { work activity. The Facility Authorization Level, as described } \\
\text { in Section } 7.2 \text { of the LLNL ISMS Description, and related } \\
\text { considerations of the facility in which the work activity is to } \\
\text { be conducted are to be included in the selection process. }\end{array}$ & See Comment for (1) & $\begin{array}{l}\text { DNT follows LLNL's Procurement } \\
\text { Procedures regarding subcontractors. }\end{array}$ & $\begin{array}{l}\text { N Program implements these requirements through } \\
\text { referenced DNT processes*. }\end{array}$ & PAY, FMC, PMC \\
\hline & (3) & $\begin{array}{l}\text { The subcontract safety requirements are to be prepared and } \\
\text { maintained consistent with the flow down requirements of } \\
\text { Contract } 48 \text {, Clause } 6.7 \text {. These safety requirements are to } \\
\text { be applied to subcontracts for work categorized per Section } \\
7.3 \text { of the LLNL ISMS Description as Work Authorization } \\
\text { Level } 2 \text { or greater. }\end{array}$ & See Comment for (1) & $\begin{array}{l}\text { DNT follows LLNL's Procurement } \\
\text { Procedures regarding subcontractors. }\end{array}$ & $\begin{array}{l}\text { N Program implements these requirements through } \\
\text { referenced DNT processes*. }\end{array}$ & PAY, FMC, PMC \\
\hline 81 & (4) & $\begin{array}{l}\text { The organization requesting a subcontract for work is to } \\
\text { evaluate the planned subcontract work and assign an } \\
\text { activity categorization consistent with the Work Activity } \\
\text { Authorization Structure. The appropriate ES\&H Team is to } \\
\text { be used to assist the requesting organization in making the } \\
\text { determination, as necessary. The appropriate ES\&H Team } \\
\text { is to be notified of all requests for a subcontract where the } \\
\text { work is categorized as Work Authorization Level } 2 \text { or } \\
\text { greater and to be used accordingly. The Procurement and } \\
\text { Materiel Department (P\&M) is to use the Contract } 48 \text { and } \\
\text { Description requirements and the categorization } \\
\text { determination to select the appropriate safety requirements } \\
\text { acording to P\&M procedures. }\end{array}$ & See Comment for (1) & $\begin{array}{l}\text { DNT follows LLNL's Procurement } \\
\text { Procedures regarding subcontractors. }\end{array}$ & $\begin{array}{l}\text { N Program implements these requirements through } \\
\text { referenced DNT processes*. }\end{array}$ & PAY, FMC, PMC \\
\hline 82 & (5) & $\begin{array}{l}\text { The subcontractor is to be informed of the work activity } \\
\text { hazards and obtain the appropriate training consistent with } \\
\text { this Description and the ES\&H Manual. }\end{array}$ & See Comment for (1) & $\begin{array}{l}\text { DNT follows LLNL's Procurement } \\
\text { Procedures regarding subcontractors. }\end{array}$ & $\begin{array}{l}\text { N Program implements these requirements through } \\
\text { referenced DNT processes*. }\end{array}$ & PAY, FMC, PMC \\
\hline 83 & $(6)$ & $\begin{array}{l}\text { A subcontractor performing work categorized as Work } \\
\text { Authorization Level } 2 \text { or greater is to be required to manage } \\
\text { and perform the work in accordance with the } \\
\text { subcontractor's safety management system, which as a } \\
\text { minimum must fulfill the requirements of Contract } 48, \\
\text { Clause } 6.7 \text {. In addition, a subcontractor performing work } \\
\text { categorized as Work Authorization Level } 4 \text { or greater is to } \\
\text { be required to document its safety management system in a } \\
\text { site- and/or job-specific safety plan. P\&M is to obtain this } \\
\text { plan. The requesting organization and the appropriate } \\
\text { ES\&H Team are to review it for operational and technical } \\
\text { accuracy and completeness. Then, together with P\&M, they } \\
\text { provide approval through P\&M. }\end{array}$ & See Comment for (1) & $\begin{array}{l}\text { DNT follows LLNL's Procurement } \\
\text { Procedures regarding subcontractors. }\end{array}$ & $\begin{array}{l}\text { N Program implements these requirements through } \\
\text { referenced DNT processes*. }\end{array}$ & PAY, FMC, PMC \\
\hline 84 & 6.2 .3 .5 & $\begin{array}{l}\text { Safety Documents Are Written So That They Are } \\
\text { Readily Understandable by the Individuals Performing } \\
\text { and Managing the Work }\end{array}$ & & & & \\
\hline 85 & (1) & $\begin{array}{l}\text { The purpose of the Laboratory's safety documents (i.e., } \\
\text { manuals, plans, and procedures is to enable all employees, } \\
\text { subcontractors, and visitors to work safely and in an } \\
\text { environmentally sound manner. }\end{array}$ & $\begin{array}{l}- \text { Chapter 1, Section 1.2.4; } \\
\text { - Chapter 2, Section 2.3 }\end{array}$ & $\begin{array}{l}\text { FSARs, FTSRs, FOSRs, OSPs, DQAP, } \\
\text { IWSs, FSPs and all DNT Directorate } \\
\text { Plans. }\end{array}$ & $\begin{array}{l}\text { N Program implements these requirements through } \\
\text { referenced DNT processes*, relevant N Program } \\
\text { procedures, the NPMP, and the OSPs and FSPs. }\end{array}$ & PAY, FMC, PMC \\
\hline
\end{tabular}


N Program Integrated Safety Management Reqiurements Matrix 2/22/00

\begin{tabular}{|c|c|c|c|c|c|c|}
\hline & A & $\mathrm{B}$ & $\mathrm{C}$ & $\mathrm{D}$ & $E$ & $\mathrm{~F}$ \\
\hline 29 & Ref. & $\begin{array}{l}\text { Requirements from the } \\
\text { LLNL ISMS Description }\end{array}$ & $\begin{array}{l}\text { LLNL Implementing Procedures \& } \\
\text { Documents }\end{array}$ & $\begin{array}{l}\text { Directorate Implementing Procedures } \\
\text { \& Documents }\end{array}$ & N Program Implementation Requirements & Responsible Positions \\
\hline 86 & (2) & $\begin{array}{l}\text { The authors and approving organizations of safety } \\
\text { documents are responsible for ensuring that instructions are } \\
\text { workable and readily understandable to the individuals } \\
\text { performing and managing the work. The authors and } \\
\text { approving organizations are likewise responsible for } \\
\text { ensuring that safety documents are consistent with } \\
\text { applicable rules and requirements. }\end{array}$ & $\begin{array}{l}\cdot \text { Chapter 1, Section 1.2.4; } \\
\cdot \text { Chapter 2, Section } 2.3\end{array}$ & $\begin{array}{l}\text { DNT implements these requirements } \\
\text { through the DNT ISMS Implementation } \\
\text { Plan. }\end{array}$ & $\begin{array}{l}\text { N Program implements these requirements through } \\
\text { referenced DNT processes*, relevant N Program } \\
\text { procedures, the NPMP, and the OSPS and FSPs. }\end{array}$ & PAY, FMC, PMC \\
\hline 87 & (3) & $\begin{array}{l}\text { In situations where requirements are particularly complex or } \\
\text { ambiguous, the organization authorizing the work is to use } \\
\text { the appropriate ES\&H professionals and other Subject } \\
\text { Matter Experts to interpret and assist in developing ways to } \\
\text { satisfy requirements. }\end{array}$ & - Chapter 2, Section 2.3 & $\begin{array}{l}\text { DNT implements these requirements } \\
\text { through the DNT ISMS Implementation } \\
\text { Plan and through individual FSPs. }\end{array}$ & $\begin{array}{l}\text { N Program implements these requirements through } \\
\text { referenced DNT processes*, relevant N Program } \\
\text { procedures, the NPMP, and the OSPs and FSPs. }\end{array}$ & PAY, FMC, PMC \\
\hline 88 & (4) & $\begin{array}{l}\text { Workers are to be provided an opportunity to participate in } \\
\text { the development of operating procedures specific to their } \\
\text { work activities. }\end{array}$ & $\begin{array}{l}\text { - Chapter 2, Section 2.3.6; } \\
\text { - Chapter 1, Section 1.3.4 }\end{array}$ & $\begin{array}{l}\text { DNT implements these requirements } \\
\text { through the DNT ISMS Implementation } \\
\text { Plan. }\end{array}$ & $\begin{array}{l}\text { N Program implements these requirements through } \\
\text { referenced DNT processes*, relevant N Program } \\
\text { procedures, the NPMP, and the OSPS and FSPs. }\end{array}$ & RI, IW \\
\hline 89 & (5) & $\begin{array}{l}\text { The resulting safety documents are to be readily available to } \\
\text { all individuals who need access to the information. }\end{array}$ & $\begin{array}{l}\text { - Chapter 1, Section 1.2.4; } \\
\text { - Chapter 2, Section 2.3 }\end{array}$ & $\begin{array}{l}\text { DNT implements these requirements } \\
\text { through the DNT ISMS Implementation } \\
\text { Plan. }\end{array}$ & $\begin{array}{l}\text { N Program implements these requirements through } \\
\text { referenced DNT processes*, relevant N Program } \\
\text { procedures, the NPMP, and the OSPs and FSPs. }\end{array}$ & RI \\
\hline 90 & 6.2.4 & $\begin{array}{l}\text { DOE Guiding Principle } 3 \text { - Competence Commensurate } \\
\text { with Responsibilities } \\
\text { Personnel posses competence commensurate with } \\
\text { responsibilities. }\end{array}$ & & & & \\
\hline 92 & 6.2.4.1 & Individuals Are Qualified to Perform Assigned Work & & & & \\
\hline 93 & (1) & $\begin{array}{l}\text { Each individual must possess the necessary skills, } \\
\text { knowledge, and abilities, including physical capabilities, to } \\
\text { carry out their assigned tasks. The base skills are to be } \\
\text { ensured by the payroll organization. }\end{array}$ & $\begin{array}{l}- \text { TPM, page1- Policy, page } 3 . \\
\text { - Chapter } 1 \text {, Sections } 1.3 .1,1.3 .4 \text { and } \\
\text { 1.3.5 }\end{array}$ & \begin{tabular}{|l|} 
DNT Training Plan and Position \\
Descriptions and Facility Training Plans, \\
FSPs, OSPs, and IWSs.
\end{tabular} & $\begin{array}{l}\text { N Program implements these requirements through } \\
\text { referenced DNT processes*, relevant N Program } \\
\text { procedures, the NPMP, and the OSPs and FSPs. } \\
\text { Payroll requirements are met through the Engineering } \\
\text { Training Plan. }\end{array}$ & PAY, FMC, PMC \\
\hline 94 & (2) & $\begin{array}{l}\text { The individual supervising the work activity is responsible } \\
\text { for identifying: }\end{array}$ & N/A & $\mathrm{N} / \mathrm{A}$ & N/A & N/A \\
\hline 95 & (a) & $\begin{array}{l}\text { the qualifications, including appropriate medical } \\
\text { certifications, and surveillance necessary to carry out the } \\
\text { work; }\end{array}$ & - Chapter 1, Section 1.3.5 & $\begin{array}{l}\text { DNT implements these requirements from } \\
\text { the ES\&H Manual, DNT Training Plan, } \\
\text { Position Descriptions, Facility Training } \\
\text { Plans, FSPs, OSPs, and IWSs. }\end{array}$ & $\begin{array}{l}\text { N Program implements these requirements through } \\
\text { referenced DNT processes*, relevant N Program } \\
\text { procedures, the NPMP, and the OSPs and FSPs. } \\
\text { Payroll requirements are met through the Engineering } \\
\text { Training Plan. }\end{array}$ & PAY, RI \\
\hline 96 & (b) & $\begin{array}{l}\text { the individuals with the qualifications and training to perform } \\
\text { the work. }\end{array}$ & - Chapter 1, Section 1.3.5 & $\begin{array}{l}\text { DNT implements these requirements from } \\
\text { the ES\&H Manual, DNT Training Plan, } \\
\text { Position Descriptions, Facility Training } \\
\text { Plans, FSPs, OSPs, and IWSs. }\end{array}$ & $\begin{array}{l}\text { N Program implements these requirements through } \\
\text { referenced DNT processes } \\
\text { procedures, the NPMP, and the OSPs and FSPs. }\end{array}$ & PAY, RI \\
\hline 97 & $\overline{6.2 .4 .2}$ & $\begin{array}{l}\text { Individuals Receive Appropriate Job-Specific Safety } \\
\text { Training }\end{array}$ & & & & \\
\hline 98 & (1) & $\begin{array}{l}\text { The individual supervising the work activity is responsible } \\
\text { for ensuring that the training necessary to do the assigned } \\
\text { work safely is identified and communicated to the Payroll } \\
\text { organization. }\end{array}$ & - Chapter 1, Section 1.3.5 & $\begin{array}{l}\text { DNT implements these requirements } \\
\text { through the DNT ISMS Implementation } \\
\text { Plan, FSPs, OSPs and IWSs. }\end{array}$ & $\begin{array}{l}\text { N Program implements these requirements through } \\
\text { referenced DNT processes*, relevant N Program } \\
\text { procedures, the NPMP, and the OSPs and FSPs. } \\
\text { Payroll requirements are met through the Engineering } \\
\text { Training Plan. }\end{array}$ & RI \\
\hline 99 & (2) & $\begin{array}{l}\text { All personnel are to receive training to perform their work in } \\
\text { a safe and environmentally sound manner. The Laboratory } \\
\text { provides the training needed to enable its employees to } \\
\text { meet safety standards and facility-and activity-specific } \\
\text { requirements. }\end{array}$ & $\begin{array}{l}\text { - Chapter 1, Section 1.3.3; and } \\
\text { - Chapter 2, Section 2.2.3 } \\
\text { - Chapter 7, Section 7.2 }\end{array}$ & $\begin{array}{l}\text { DNT implements these requirements } \\
\text { directly from the ES\&H Manual and } \\
\text { Training Program Manual and } \\
\text { directorate/facility Training Plans, FSPs, } \\
\text { OSPs and IWSs. }\end{array}$ & $\begin{array}{l}\text { N Program implements these requirements through } \\
\text { referenced DNT processes*, relevant N Program } \\
\text { procedures, the NPMP, and the OSPs and FSPs. } \\
\text { Payroll requirements are met through the Engineering } \\
\text { Training Plan. }\end{array}$ & PAY, RI \\
\hline
\end{tabular}


N Program Integrated Safety Management Reqiurements Matrix 2/22/00

\begin{tabular}{|c|c|c|c|c|c|c|}
\hline & A & $\mathrm{B}$ & $\mathrm{C}$ & $\mathrm{D}$ & $E$ & $\mathrm{~F}$ \\
\hline 29 & Ref. & $\begin{array}{l}\text { Requirements from the } \\
\text { LLNL ISMS Description }\end{array}$ & $\begin{array}{l}\text { LLNL Implementing Procedures \& } \\
\text { Documents }\end{array}$ & $\begin{array}{c}\text { Directorate Implementing Procedures } \\
\text { \& Documents }\end{array}$ & N Program Implementation Requirements & Responsible Positions \\
\hline 100 & (3) & $\begin{array}{l}\text { Accomplishment of safety training is documented in the } \\
\text { Livermore Training Records and Information Network } \\
\text { (LTRAIN). }\end{array}$ & - Chapter 2, Section 2.2.3 & $\begin{array}{l}\text { DNT implements these requirements } \\
\text { through the DNT ISMS Implementation } \\
\text { Plan and the DNT Training Plan. }\end{array}$ & $\begin{array}{l}\text { N Program implements these requirements through } \\
\text { referenced DNT processes } \\
\text { procedures, and the OSPs and FSPant N Program } \\
\text { requirements are met through the Engineering Training } \\
\text { Plan. }\end{array}$ & PAY \\
\hline 101 & (4) & $\begin{array}{l}\text { The organization authorizing work is responsible for } \\
\text { ensuring that the resources necessary for required safety } \\
\text { training are provided by that organization or another } \\
\text { appropriate organization. }\end{array}$ & $\begin{array}{l}- \text { Chapter 1, Sections 1.3.3 and 1.3.4; } \\
\text { - Chapter 2, Section 2.2.3; and }\end{array}$ & $\begin{array}{l}\text { DNT implements these requirements } \\
\text { through the DNT ISMS Implementation } \\
\text { Plan, FSPs, OSPs and IWSs. }\end{array}$ & $\begin{array}{l}\text { N Program implements these requirements through } \\
\text { referenced DNT processes } \\
\text { procedures, the NPMP, and the OSPS N and FSPs. }\end{array}$ & FMC, PMC \\
\hline 102 & (5) & $\begin{array}{l}\text { Payroll organizations are to assure that their personnel have } \\
\text { the required training. }\end{array}$ & $\begin{array}{l}\text { - Chapter 1, Section 1.3.3; } \\
\text { - Chapter 2, Section 2.2.3 }\end{array}$ & $\begin{array}{l}\text { DNT implements these requirements } \\
\text { through the DNT ISMS Implementation } \\
\text { Plan and DNT Training Plan. }\end{array}$ & $\begin{array}{l}\text { N Program implements these requirements through } \\
\text { referenced DNT processes*, relevant N Program } \\
\text { procedures, the NPMP, and the OSPS and FSPS. }\end{array}$ & PAY \\
\hline 103 & (6) & $\begin{array}{l}\text { The work activity supervisor is to ensure that the personnel } \\
\text { supporting their activities have the required safety training, } \\
\text { including facility specific training. }\end{array}$ & $\begin{array}{l}\text { - Chapter 1, Section 1.3.5; } \\
\text { - Chapter 2, Section 2.2.3 }\end{array}$ & $\begin{array}{l}\text { DNT implements these requirements } \\
\text { through the DNT ISMS Implementation } \\
\text { Plan FSPs, OSPs and IWSs. }\end{array}$ & $\begin{array}{l}\text { N Program implements these requirements through } \\
\text { referenced DNT processes*, relevant N Program } \\
\text { procedures, and the OSPs and FSPs. }\end{array}$ & RI \\
\hline 104 & 6.2 .4 .3 & Individuals Receive Appropriate ISMS Training & & & & \\
\hline 105 & (1) & $\begin{array}{l}\text { All Laboratory employees are to be trained in the principles } \\
\text { and functions of ISMS at a level appropriate for their specific } \\
\text { job duties and responsibilities. The Laboratory is } \\
\text { responsible for developing the institutional ISMS training } \\
\text { courses. }\end{array}$ & $\begin{array}{l}\cdot \text { Chapter 2, Section } 2.2 \cdot \text { Chapter } 7 \text {, } \\
\text { Section } 7.2\end{array}$ & $\begin{array}{l}\text { The institutional ISMS training has been } \\
\text { delivered to DNT employees as part of } \\
\text { ISMS roll-out. }\end{array}$ & $\begin{array}{l}\text { N Program implements these requirements through } \\
\text { referenced DNT processes*, relevant N Program } \\
\text { procedures, the NPMP, and the OSPs and FSPs. }\end{array}$ & PAY \\
\hline 106 & (2) & $\begin{array}{l}\text { Each Directorate is responsible for ensuring that their } \\
\text { employees receive ISMS training, including facility-and } \\
\text { activity-specific training as appropriate, in an effective and } \\
\text { timely manner. }\end{array}$ & - Chapter 2, Section 2.2 & \begin{tabular}{|l|} 
Training for DNT specific ISM issues has \\
been developed and partially delivered.
\end{tabular} & $\begin{array}{l}\text { N Program implements these requirements through } \\
\text { referenced DNT processes*, relevant N Program } \\
\text { procedures, the NPMP, and the OSPS and FSPs. }\end{array}$ & PAY \\
\hline 107 & (3) & $\begin{array}{l}\text { Each Directorate is responsible for assuring that the } \\
\text { required ISMS training is appropriately documented in the } \\
\text { LTRAIN system. }\end{array}$ & - Chapter 2, Section 2.2 & \begin{tabular}{|l|} 
DNT implements these requirements \\
through the DNT ISMS Implementation \\
Plan and through the DNT Training Plan.
\end{tabular} & $\begin{array}{l}\text { N Program implements these requirements through } \\
\text { referenced DNT processes*, and relevant N Program } \\
\text { Procedures. }\end{array}$ & PAY \\
\hline $\begin{array}{ll}108 \\
109 \\
\end{array}$ & 6.3 & $\begin{array}{l}\text { Work Planning and Prioritization } \\
\text { DOE Core Function } 1 \text { - Define the Scope of Work }\end{array}$ & & & & \\
\hline$\frac{10}{110}$ & $\overline{6.3 .1 .1}$ & The Work Activity Is Defined & & & & \\
\hline 111 & (1) & $\begin{array}{l}\text { The organization authorizing the work activity is responsible } \\
\text { for: }\end{array}$ & $\mathrm{N} / \mathrm{A}$ & $\mathrm{N} / \mathrm{A}$ & $\mathrm{N} / \mathrm{A}$ & $\mathrm{N} / \mathrm{A}$ \\
\hline 112 & (a) & stating the technical objectives; & $\begin{array}{l}\text { - Chapter 1, Section1.3.4; } \\
\text { - Chapter } 2 \text { Section 2.2.1 }\end{array}$ & $\begin{array}{l}\text { DNT implements these requirements } \\
\text { through the DNT ISMS Implementation } \\
\text { Plan, FSARs, FSPs, OSPs, and IWSs. }\end{array}$ & $\begin{array}{l}\text { N Program implements these requirements through } \\
\text { referenced DNT processes*, relevant N Program } \\
\text { procedures, the NPMP, and the OSPs and FSPs. }\end{array}$ & PMC \\
\hline 113 & (b) & defining the work elements to be performed; & $\begin{array}{l}\text { - Chapter 1, Section1.3.4; } \\
\text { - Chapter } 2 \text { Section 2.2.1 }\end{array}$ & $\begin{array}{l}\text { DNT implements these requirements } \\
\text { through the DNT ISMS Implementation } \\
\text { Plan, FSARs, FSPs, OSPs, and IWSs. }\end{array}$ & $\begin{array}{l}\text { N Program implements these requirements through } \\
\text { referenced DNT processes } \\
\text { procedures, the NPMP, and the OSPS and FSPs. }\end{array}$ & FMC, PMC \\
\hline 114 & (c) & identifying the facility in which the work will take place; & $\begin{array}{l}\text { - Chapter 1, Section1.3.4; } \\
\text { - Chapter } 2 \text { Section 2.2.1 }\end{array}$ & $\begin{array}{l}\text { DNT implements these requirements } \\
\text { through the DNT ISMS Implementation } \\
\text { Plan, FSARs, FSPs, OSPs, and IWSs. }\end{array}$ & $\begin{array}{l}\text { N Program implements these requirements through } \\
\text { referenced DNT processes, relevant N Program } \\
\text { procedures, the NPMP, and the OSPs and FSPs. }\end{array}$ & FMC, PMC \\
\hline 115 & (d) & $\begin{array}{l}\text { Identifying the individual who will be supervising the work } \\
\text { activity. }\end{array}$ & $\begin{array}{l}\text { - Chapter 1, Section1.3.4; } \\
\text { - Chapter } 2 \text { Section 2.2.1 }\end{array}$ & $\begin{array}{l}\text { DNT implements these requirements } \\
\text { through the DNT ISMS Implementation } \\
\text { Plan. FSARs. FSPs, OSPS, and IWSs. }\end{array}$ & $\begin{array}{l}\text { N Program implements these requirements through } \\
\text { referenced DNT processes, relevant N Program } \\
\text { procedures, the NPMP, and the OSPS and FSPs. }\end{array}$ & FMC, PMC \\
\hline 116 & $(2)$ & $\begin{array}{l}\text { The management chain that results from these } \\
\text { determinations is responsible for ensuring the work activity } \\
\text { is properly analyzed, controlled, performed, and monitored. }\end{array}$ & $\begin{array}{l}\text { - Chapter1, Section 1.3.4 and 1.4; and } \\
\text { - Chapter 2, Section 2.2.1 }\end{array}$ & $\begin{array}{l}\text { DNT implements these requirements } \\
\text { through the DNT ISMS Implementation } \\
\text { Plan, FISMSPs, FSPs, OSPs, IWSs. }\end{array}$ & $\begin{array}{l}\text { N Program implements these requirements through } \\
\text { referenced DNT processes, relevant N Program } \\
\text { procedures, the NPMP, and the OSPS and FSPs. }\end{array}$ & PAY, FMC, PMC \\
\hline 117 & $\overline{6.3 .1 .2}$ & The Graded Approach Process Is Consistently Applied & & & & \\
\hline 118 & (1) & $\begin{array}{l}\text { An individual may initiate and perform a work activity without } \\
\text { the imposition of formal work controls if it involves only } \\
\text { activities commonoly performed by the public as defined in } \\
\text { the ES\&H Manual. In no instance shall an individual initiate } \\
\text { or perform a work activity not commonly performed by the } \\
\text { public without the approval of an appropriate person in their } \\
\text { management chain. }\end{array}$ & $\cdot$ Chapter 2, Section 2.1.2 & $\begin{array}{l}\text { DNT implements these requirements } \\
\text { through the DNT ISMS Implementation } \\
\text { Plan, FSPs and OSPs. }\end{array}$ & $\begin{array}{l}\text { N Program implements these requirements through } \\
\text { referenced DNT processes*, relevant N Program } \\
\text { procedures, and the OSPs and FSPs. }\end{array}$ & IW \\
\hline
\end{tabular}

* "Referenced DNT processes" are identified in the companion DNT column entitled "Directorate Implementing Procedures and Documents" 
N Program Integrated Safety Management Reqiurements Matrix 2/22/00

\begin{tabular}{|c|c|c|c|c|c|c|}
\hline & A & $\mathrm{B}$ & $\mathrm{C}$ & $\mathrm{D}$ & $E$ & $\mathrm{~F}$ \\
\hline 29 & Ref. & $\begin{array}{l}\text { Requirements from the } \\
\text { LLNL ISMS Description }\end{array}$ & $\begin{array}{l}\text { LLNL Implementing Procedures \& } \\
\text { Documents }\end{array}$ & $\begin{array}{c}\text { Directorate Implementing Procedures } \\
\text { \& Documents }\end{array}$ & N Program Implementation Requirements & Responsible Positions \\
\hline 119 & $\overline{(2)}$ & $\begin{array}{l}\text { It is the responsibility of the organization authorizing work to } \\
\text { ensure that the greater the hazards associated with an } \\
\text { activity the more rigorous the work planning process that will } \\
\text { be required. The objective of the work planning process is } \\
\text { to ensure the hazards associated with the work activity are } \\
\text { clearly understood and appropriately addressed. To ensure } \\
\text { this objective is met, relevant ES\&H professionals and } \\
\text { Subject Matter Experts are to be used during the work } \\
\text { planning process, as appropriate. }\end{array}$ & $\begin{array}{l}\text { - Chapter 1, Sections 1.3.4; } \\
\text { - Chapter 2, Section 2.1.2, and } \\
\text { Appendix 2-A }\end{array}$ & $\begin{array}{l}\text { DNT implements these requirements } \\
\text { through the DNT ISMS Implementation } \\
\text { Plan, FSPs, OSPs, and IWSs. }\end{array}$ & $\begin{array}{l}\text { N Program implements these requirements through } \\
\text { referenced DNT processes }{ }^{\star} \text {, relevant N Program } \\
\text { procedures, and the OSPs and FSPs. }\end{array}$ & FMC, PMC \\
\hline 120 & (3) & $\begin{array}{l}\text { Consistent with the provisions and levels described in } \\
\text { Section } 7 \text { of the LLNL ISMS Description and the ES\&H } \\
\text { Manual, the individuals responsible for: }\end{array}$ & N/A & N/A & N/A & N/A \\
\hline 121 & (a) & authorizing the work activity; & $\begin{array}{l}\text { - Chapter 1, Section 1.3.4; } \\
\text { - Chapter 2, Section 2.2.2 and } \\
\text { Appendix 2-A }\end{array}$ & $\begin{array}{l}\text { DNT implements these requirements } \\
\text { through the DNT ISMS Implementation } \\
\text { Plan, FSPs, OSPs, and IWSs. }\end{array}$ & $\begin{array}{l}\text { N Program implements these requirements through } \\
\text { referenced DNT processes }{ }^{\star} \text {, relevant N Program } \\
\text { procedures, the NPMP, and the OSPs and FSPs. }\end{array}$ & FMC, PMC \\
\hline 122 & (b) & ensuring the facility and/or operational safety envelope; & $\begin{array}{l}\text { - Chapter 1, Section 1.3.7; } \\
\text { - Chapter 2, Section 2.2.2 and } \\
\text { Appendix 2-A }\end{array}$ & $\begin{array}{l}\text { DNT implements these requirements } \\
\text { through the DNT ISMS Implementation } \\
\text { Plan, FSARs, FTSRs, FOSRs, FSPs, } \\
\text { OSPs, and IWSs. }\end{array}$ & $\begin{array}{l}\text { N Program implements these requirements through } \\
\text { referenced DNT processes }{ }^{\star} \text {, relevant N Program } \\
\text { procedures, the NPMP, and the OSPs and FSPs. }\end{array}$ & FMC, PMC \\
\hline 123 & (c) & supervising the work; & $\begin{array}{l}\text { - Chapter 1, Section 1.3.5; } \\
\text { - Chapter 2, Section 2.2.2 and } \\
\text { Appendix 2-A }\end{array}$ & $\begin{array}{l}\text { DNT implements these requirements } \\
\text { through the DNT ISMS Implementation } \\
\text { Plan, FSPs, OSPs, and IWSs. }\end{array}$ & $\begin{array}{l}\text { N Program implements these requirements through } \\
\text { referenced DNT processes }{ }^{\star} \text {, relevant N Program } \\
\text { procedures, the NPMP, and the OSPs and FSPs. }\end{array}$ & $\mathrm{RI}$ \\
\hline 124 & (d) & $\begin{array}{l}\text { providing the safety support are to be involved in the } \\
\text { analysis of the hazards and a determination of the } \\
\text { appropriate work controls to be applied to the work activity. }\end{array}$ & $\begin{array}{l}\text { - Chapter 1, Section 1.3.10; } \\
\text { - Chapter 2, Section 2.2.2 and } \\
\text { Appendix 2-A }\end{array}$ & $\begin{array}{l}\text { DNT implements these requirements } \\
\text { through the DNT ISMS Implementation } \\
\text { Plan, FSPs, OSPs, and IWSs. }\end{array}$ & $\begin{array}{l}\text { N Program implements these requirements through } \\
\text { referenced DNT processes }{ }^{*} \text {, relevant N Program } \\
\text { procedures, the NPMP, and the OSPs and FSPs. }\end{array}$ & PAY, FMC, PMC \\
\hline 125 & $(4)$ & $\begin{array}{l}\text { Work is to be authorized by the appropriate level of } \\
\text { management as described in Section } 7 \text { of the LLNL ISMS } \\
\text { Description and expanded upon in the ES\&H Manual. }\end{array}$ & $\begin{array}{l}\text { - Chapter 1, Sections 1.3.4 \& 1.4; } \\
\text { - Chapter 2, Section 2.2.4, and } \\
\text { Appendix 2-A }\end{array}$ & $\begin{array}{l}\text { DNT implements these requirements } \\
\text { through the DNT ISMS Implementation } \\
\text { Plan, FSPs, OSPS, and IWSs. }\end{array}$ & $\begin{array}{l}\text { N Program implements these requirements through } \\
\text { referenced DNT processes }{ }^{\star} \text {, relevant N Program } \\
\text { procedures, the NPMP, and the OSPs and FSPs. }\end{array}$ & FMC, PMC \\
\hline $\begin{array}{ll}126 \\
127\end{array}$ & $\overline{6.3 .2}$ & $\begin{array}{l}\text { DOE Guiding Principle } 4 \text { - Balanced Priorities } \\
\text { Resource allocations are balanced, making ES\&H a priority } \\
\text { in project planning and execution. }\end{array}$ & & & & \\
\hline 128 & 6.3 .2 .1 & $\begin{array}{l}\text { Resource Planning Processes Ensure Balanced } \\
\text { Priorities }\end{array}$ & & & & \\
\hline 129 & (1) & $\begin{array}{l}\text { The organization authorizing work is responsible for } \\
\text { allocating sufficient resources to ensure safe and compliant } \\
\text { operations. }\end{array}$ & - Chapter 1 , Sections 1.3 .3 and 1.3 .4 & $\begin{array}{l}\text { DNT implements these requirements } \\
\text { through the DNT ISMS Implementation } \\
\text { Plan, FSPs, OSPS, and IWSs. }\end{array}$ & $\begin{array}{l}\text { N Program implements these requirements through } \\
\text { referenced DNT processes }{ }^{*} \text {, relevant N Program } \\
\text { procedures, the NPMP, and the OSPs and FSPs. }\end{array}$ & FMC, PMC \\
\hline 130 & (2) & $\begin{array}{l}\text { A work activity proceeds only with a reasonable expectation } \\
\text { by the management chain that there will be sufficient } \\
\text { resources to ensure safety requirements are satisfied over } \\
\text { the length of the project, including closeout activities. }\end{array}$ & $\begin{array}{l}\text { - Chapter 1, Section 1.3.3; } \\
\text { - Chapter 2, Section 2.2.4 }\end{array}$ & $\begin{array}{l}\text { DNT implements these requirements } \\
\text { through the DNT ISMS Implementation } \\
\text { Plan, FSPs, OSPs, and IWSs. }\end{array}$ & $\begin{array}{l}\text { N Program implements these requirements through } \\
\text { referenced DNT processes }{ }^{*} \text {, relevant N Program } \\
\text { procedures, the NPMP, and the OSPs and FSPs. }\end{array}$ & FMC, PMC \\
\hline $\begin{array}{ll}131 \\
132 \\
\end{array}$ & \begin{tabular}{|l|}
6.4 \\
6.4 .1
\end{tabular} & $\begin{array}{l}\text { Hazards Analysis } \\
\text { DOE Core Function } 2 \text { - Analyze the Hazards }\end{array}$ & & & & \\
\hline 133 & 6.4.1.1 & $\begin{array}{l}\text { Hazards Are Identified and Analyzed for All Work } \\
\text { Activities }\end{array}$ & & & & \\
\hline 134 & (1) & $\begin{array}{l}\text { The organization authorizing a work activity is responsible } \\
\text { for ensuring that the associated hazards are identified. } \\
\text { ES\&H professionals are to be used in the hazard } \\
\text { identification process, as appropriate. Workers are to be } \\
\text { provided an opportunity to participate in the process of } \\
\text { identifying hazards. }\end{array}$ & $\begin{array}{l}\text { - Chapter 1, Section 1.3.4 and 1.3.10; } \\
\text { - Chapter 2, Section 2.2.1, 2.2.2 }\end{array}$ & $\begin{array}{l}\text { DNT implements these requirements } \\
\text { through the DNT ISMS Implementation } \\
\text { Plan, FSPs, OSPs, and IWSs. }\end{array}$ & $\begin{array}{l}\text { N Program implements these requirements through } \\
\text { referenced DNT processes }{ }^{*} \text {, relevant N Program } \\
\text { procedures, the NPMP, and the OSPs and FSPs. }\end{array}$ & FMC, PMC \\
\hline 135 & (2) & $\begin{array}{l}\text { Hazards are to be identified and analyzed consistent with } \\
\text { the provisions of the ES\&H Manual. }\end{array}$ & $\begin{array}{l}\text { - Chapter 1, Section 1.3.4 and 1.3.10; } \\
\text { - Chapter 2, 2.2.2 }\end{array}$ & $\begin{array}{l}\text { DNT implements these requirements } \\
\text { through the DNT ISMS Implementation } \\
\text { Plan, FSPs, OSPs, and IWSs. }\end{array}$ & $\begin{array}{l}\text { N Program implements these requirements through } \\
\text { referenced DNT processes }{ }^{*} \text {, relevant N Program } \\
\text { procedures, the NPMP, and the OSPs and FSPs. }\end{array}$ & FMC, PMC \\
\hline
\end{tabular}


N Program Integrated Safety Management Reqiurements Matrix 2/22/00

\begin{tabular}{|c|c|c|c|c|c|c|}
\hline & A & $\mathrm{B}$ & $\mathrm{C}$ & $\mathrm{D}$ & $\mathrm{E}$ & $\mathrm{F}$ \\
\hline 29 & Ref. & $\begin{array}{l}\text { Requirements from the } \\
\text { LLNL ISMS Description }\end{array}$ & $\begin{array}{l}\text { LLNL Implementing Procedures \& } \\
\text { Documents }\end{array}$ & $\begin{array}{l}\text { Directorate Implementing Procedures } \\
\text { \& Documents }\end{array}$ & N Program Implementation Requirements & Responsible Positions \\
\hline 136 & $\overline{(3)}$ & $\begin{array}{l}\text { Each individual is responsible for making conscious } \\
\text { considerations of the safety implications of their actions } \\
\text { whether or not formal hazards analysis and documentation } \\
\text { are required. }\end{array}$ & $\begin{array}{l}\text { - Chapter 1, Section 1.3.4; } \\
\text { - Chapter } 2 \text { Section 2.2.2 and, } \\
\text { Appendix 2-A }\end{array}$ & $\begin{array}{l}\text { DNT implements these requirements } \\
\text { through the DNT ISMS Implementation } \\
\text { Plan, FSPs, OSPs, and IWSs. }\end{array}$ & $\begin{array}{l}\text { N Program implements these requirements through } \\
\text { referenced DNT processes*, relevant N Program } \\
\text { procedures, the NPMP, and the OSPs and FSPs. }\end{array}$ & IIW \\
\hline 137 & 6.4.1.2 & $\begin{array}{l}\text { Integration Work Sheets Are Developed for Appropriate } \\
\text { Work Activities }\end{array}$ & & & & \\
\hline 138 & (1) & $\begin{array}{l}\text { The intent of the Integration Work Sheet (IWS) is to ensure } \\
\text { front-end identification of all hazards associated with a work } \\
\text { activity. An IWS is required when a work activity is beyond } \\
\text { that commonly performed by the public. The organization } \\
\text { authorizing a work activity is responsible for ensuring that } \\
\text { an IWS is prepared, reviewed, and approved consistent with } \\
\text { the provisions of Section } 7 \text { of the LLNL ISMS Description } \\
\text { and the ES\&H Manual. The format and instructions for the } \\
\text { IWS are contained in the ES\&H Manual. The completed } \\
\text { IWS provides the authorization for the work activity once a } \\
\text { prestart review confirms readiness. }\end{array}$ & $\begin{array}{l}\text { - Chapter 2, Section 2.3.4; Appendix 2- } \\
\text { A, Appendix 2-B }\end{array}$ & $\begin{array}{l}\text { DNT implements these requirements } \\
\text { through the DNT ISMS Implementation } \\
\text { Plan. }\end{array}$ & $\begin{array}{l}\text { N Program implements these requirements through } \\
\text { referenced DNT processes*, relevant N Program } \\
\text { procedures, the NPMP, and the OSPs and FSPs. }\end{array}$ & FMC, PMC \\
\hline 139 & (2) & $\begin{array}{l}\text { At the discretion of the organization authorizing the work, } \\
\text { preparation of the IWS may be delegated to either the } \\
\text { organization responsible for a) supervising the work activity } \\
\text { or b) the facility safety envelope. Any delegation of the } \\
\text { responsibility for preparing the IWS is to be documented as } \\
\text { described in the ES\&H Manual. }\end{array}$ & - Chapter 2, Section 2.3.4 & $\begin{array}{l}\text { DNT implements these requirements } \\
\text { through the DNT ISMS Implementation } \\
\text { Plan. }\end{array}$ & $\begin{array}{l}\text { N Program implements these requirements through } \\
\text { referenced DNT processes }, \text { relevant N Program } \\
\text { procedures, the NPMP, and the OSPs and FSPs. }\end{array}$ & FMC, PMC \\
\hline 140 & (3) & $\begin{array}{l}\text { The organization responsible for ensuring the facility and/or } \\
\text { operational safety envelope(s) is to review and concur with } \\
\text { the IWS. }\end{array}$ & - Chapter 2, Section 2.1.2 & $\begin{array}{l}\text { DNT implements these requirements } \\
\text { through the DNT ISMS Implementation } \\
\text { Plan. }\end{array}$ & $\begin{array}{l}\text { N Program implements these requirements through } \\
\text { referenced DNT processes*, relevant N Program } \\
\text { procedures, the NPMP, and the OSPS and FSPs. }\end{array}$ & FMC, PMC \\
\hline 141 & 6.4.1.3 & $\begin{array}{l}\text { Appropriate Sections of the ES\&H Manual Are Applied } \\
\text { in the Process of Analyzing Hazards }\end{array}$ & & & & \\
\hline 142 & (1) & $\begin{array}{l}\text { The specific hazards identified with the work activity are to } \\
\text { be analyzed according to the requirements of the applicable } \\
\text { sections of the ES\&H Manual and by the use, as necessary, } \\
\text { of the appropriate ES\&H professionals. }\end{array}$ & $\begin{array}{l}\text { - Chapter 1, Section 1.3.4; } \\
\text { - Chapter 2, Section 2.2.2 }\end{array}$ & $\begin{array}{l}\text { DNT implements these requirements } \\
\text { through the DNT ISMS Implementation } \\
\text { Plan, FSPs, OSPs, and IWSs. }\end{array}$ & $\begin{array}{l}\text { N Program implements these requirements through } \\
\text { referenced DNT processes*, relevant N Program } \\
\text { procedures, the NPMP, and the OSPS and FSPs. }\end{array}$ & FMC, PMC \\
\hline 143 & (2) & $\begin{array}{l}\text { The identified hazards are to be clearly communicated to all } \\
\text { involved in the activity. }\end{array}$ & $\begin{array}{l}\text { - Chapter 1, Section 1.3.5; } \\
\text { - Chapter 2, Sections 2.2.2 and 2.2.4 }\end{array}$ & $\begin{array}{l}\text { DNT implements these requirements } \\
\text { through the DNT ISMS Implementation } \\
\text { Plan, FSPs, OSPs, and IWSs. }\end{array}$ & $\begin{array}{l}\text { N Program implements these requirements through } \\
\text { referenced DNT processes }, \text { relevant N Program } \\
\text { procedures, the NPMP, and the OSPS and FSPs. }\end{array}$ & RI \\
\hline 144 & (3) & $\begin{array}{l}\text { The organization authorizing the work activity and the } \\
\text { individual supervising the work are responsible for } \\
\text { periodically reviewing the hazards associated with the work } \\
\text { activity as described in the ES\&H Manual. }\end{array}$ & $\begin{array}{l}\text { Chapter 1, Sections 1.3.4 and 1.3.5; } \\
\text { - Chapter 2, Section 2.2.5 }\end{array}$ & $\begin{array}{l}\text { DNT implements these requirements } \\
\text { through the DNT ISMS Implementation } \\
\text { Plan, FSPs, OSPs and IWSs. }\end{array}$ & $\begin{array}{l}\text { N Program implements these requirements through } \\
\text { referenced DNT processes*, relevant N Program } \\
\text { procedures, and the OSPs and FSPs. }\end{array}$ & FMC, PMC, RI \\
\hline 145 & 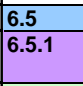 & $\begin{array}{l}\text { Hazard Mitigation and Control } \\
\text { DOE Core Function } 3 \text { - Develop and Implement Hazard } \\
\text { Controls }\end{array}$ & & & & \\
\hline 147 & \begin{tabular}{|l|}
6.5 .1 .1 \\
\end{tabular} & $\begin{array}{l}\text { A Uniform Process Governs Safety Procedure } \\
\text { Development }\end{array}$ & & & & \\
\hline 148 & (1) & $\begin{array}{l}\text { A uniform process is to be applied across the Laboratory for } \\
\text { the development of safety-related procedures consistent } \\
\text { with the provisions established in the ES\&H Manual. This } \\
\text { process identifies when procedures are to be developed, } \\
\text { specifies content based upon the hazards being managed, } \\
\text { and provides a recommended format for structuring the } \\
\text { procedure. }\end{array}$ & - Supplement 2.01 & $\begin{array}{l}\text { DNT implements these requirements } \\
\text { through the DNT ISMS Implementation } \\
\text { Plan. Building } 332 \text { has a specific Policy } \\
\text { on Procedures. }\end{array}$ & $\begin{array}{l}\text { N Program implements these requirements through } \\
\text { referenced DNT processes*, relevant N Program } \\
\text { procedures, the NPMP, and the OSPs and FSPs. }\end{array}$ & FMC, PMC \\
\hline
\end{tabular}


N Program Integrated Safety Management Reqiurements Matrix 2/22/00

\begin{tabular}{|c|c|c|c|c|c|c|}
\hline & A & $\mathrm{B}$ & $\mathrm{C}$ & $\mathrm{D}$ & $\mathrm{E}$ & $\mathrm{F}$ \\
\hline 29 & Ref. & $\begin{array}{l}\text { Requirements from the } \\
\text { LLNL ISMS Description }\end{array}$ & $\begin{array}{l}\text { LLNL Implementing Procedures \& } \\
\text { Documents }\end{array}$ & \begin{tabular}{|c|} 
Directorate Implementing Procedures \\
\& Documents
\end{tabular} & N Program Implementation Requirements & Responsible Positions \\
\hline 149 & 6.5.1.2 & $\begin{array}{l}\text { Requirements in the ES\&H Manual Are Applied in the } \\
\text { Process of Developing and Implementing Controls }\end{array}$ & & & & \\
\hline 150 & (1) & $\begin{array}{l}\text { The individual supervising the work activity is responsible } \\
\text { for ensuring that tailored controls are developed for each } \\
\text { hazard associated with the work activity. The tailored } \\
\text { controls are to be developed and implemented consistent } \\
\text { with Section } 7 \text { of the LLNL ISMS Description and the ES\&H } \\
\text { Manual. }\end{array}$ & $\begin{array}{l}\text { - Chapter 1, Section 1.3.5; } \\
\text { - Chapter 2, Section 2.2.3 }\end{array}$ & $\begin{array}{l}\text { DNT implements these requirements } \\
\text { through the DNT ISMS Implementation } \\
\text { Plan, FSPs, OSPs, and IWSs. }\end{array}$ & $\begin{array}{l}\text { N Program implements these requirements through } \\
\text { referenced DNT processes }{ }^{*} \text {, relevant N Program } \\
\text { procedures, the NPMP, and the OSPs and FSPs. }\end{array}$ & RI \\
\hline 151 & (2) & $\begin{array}{l}\text { As appropriate, Subject Matter Experts are to be used in the } \\
\text { development of work controls. }\end{array}$ & $\begin{array}{l}\text { - Chapter 1, Section 1.3.10; and } \\
\text { - Chapter 2, Section 2.2.3 }\end{array}$ & $\begin{array}{l}\text { DNT implements these requirements } \\
\text { through the DNT ISMS Implementation } \\
\text { Plan, FSPs, OSPs, and IWSs. }\end{array}$ & $\begin{array}{l}\text { N Program implements these requirements through } \\
\text { referenced DNT processes", relevant N Program } \\
\text { procedures, and the NPMP. }\end{array}$ & RI \\
\hline 152 & (3) & $\begin{array}{l}\text { Workers are to be provided an opportunity to participate in } \\
\text { the development of the operating procedures. }\end{array}$ & $\begin{array}{l}\text { - Chapter 1, Section 1.3.4; and } \\
\text { - Chapter 2, Sections 2.2.4 and 2.3.6 }\end{array}$ & $\begin{array}{l}\text { DNT implements these requirements } \\
\text { through the DNT ISMS Implementation } \\
\text { Plan, FSPs, OSPs, IWSs and OPs. }\end{array}$ & $\begin{array}{l}\mathrm{N} \text { Program implements these requirements through } \\
\text { referenced DNT processes, }{ }^{*} \text { relevant } \mathrm{N} \text { Program } \\
\text { procedures, the NPMP, and the OSPs and FSPs. }\end{array}$ & RI \\
\hline 153 & (4) & $\begin{array}{l}\text { The organization authorizing work is responsible for } \\
\text { approving the work controls. }\end{array}$ & $\begin{array}{l}\text { - Chapter 1, Section 1.3.4; } \\
\text { - Chapter 2, Section 2.2.4 }\end{array}$ & $\begin{array}{l}\text { DNT implements these requirements } \\
\text { through the DNT ISMS Implementation } \\
\text { Plan, FSPS, OSPS, and IWSs. }\end{array}$ & $\begin{array}{l}\text { N Program implements these requirements through } \\
\text { referenced DNT processes }{ }^{\star} \text {, relevant N Program } \\
\text { procedures, the NPMP, and the OSPs and FSPs. }\end{array}$ & FMC, PMC \\
\hline 154 & (5) & $\begin{array}{l}\text { The designated controls are to be clearly communicated to } \\
\text { all involved in the activity. }\end{array}$ & $\begin{array}{l}\text { - Chapter 1, Section 1.3.5; and } \\
\text { - Chapter 2, Section 2.2.4 }\end{array}$ & $\begin{array}{l}\text { DNT implements these requirements } \\
\text { through the DNT ISMS Implementation } \\
\text { Plan, FSPs, OSPS, and IWSs. }\end{array}$ & $\begin{array}{l}\text { N Program implements these requirements through } \\
\text { referenced DNT processes }{ }^{\star} \text {, relevant } N \text { Program } \\
\text { procedures, the NPMP, and the OSPS and FSPs. }\end{array}$ & RI \\
\hline 155 & $(6)$ & $\begin{array}{l}\text { The organization authorizing the work activity and the } \\
\text { individual supervising the work are responsible for } \\
\text { periodically reviewing and ensuring the adequacy of the } \\
\text { controls associated with the work activity. }\end{array}$ & $\begin{array}{l}\text { - Chapter 1, Sections 1.3.4 and 1.3.5; } \\
\text { - Chapter 2, Section 2.2.5 }\end{array}$ & $\begin{array}{l}\text { DNT implements these requirements } \\
\text { through the DNT ISMS Implementation } \\
\text { Plan, FSPs, OSPs, and IWSs. }\end{array}$ & $\begin{array}{l}\text { N Program implements these requirements through } \\
\text { referenced DNT processes, }{ }^{*} \text { relevant N Program } \\
\text { procedures, the NPMP, and the OSPs and FSPs. }\end{array}$ & FMC, PMC, RI \\
\hline 156 & 6.5 .2 & $\begin{array}{l}\text { DOE Guiding Principle } 5 \text { - Identification of Safety } \\
\text { Standards and Requirements } \\
\text { Safety standards and requirements are identified and } \\
\text { implemented. The basis and particulars are presented in } \\
\text { Sections } 10 \text { and } 12 \text {. }\end{array}$ & & & & \\
\hline 158 & 6.5.2.1 & Programs for Preventing Injuries Are Defined & & & & \\
\hline 159 & (1) & $\begin{array}{l}\text { Each Directorate is responsible for having in place defined } \\
\text { programs to prevent injuries. An ergonomics program } \\
\text { developed consistent with the ES\&H Manual is an example } \\
\text { of a defined program to prevent injuries. }\end{array}$ & $\begin{array}{l}\text { - Chapter 2, Appendix 2-G "Injury } \\
\text { Prevention Program" }\end{array}$ & $\begin{array}{l}\text { DNT implements this requirement through } \\
\text { the DNT ISMS Implementation Plan. }\end{array}$ & $\begin{array}{l}\text { N Program implements these requirements through } \\
\text { referenced DNT processes }{ }^{\star} \text {. }\end{array}$ & PAY \\
\hline 160 & (2) & $\begin{array}{l}\text { Each Directorate is responsible for analyzing all the injuries } \\
\text { associated with their organization's operations and facilities. }\end{array}$ & $\begin{array}{l}\text { - Chapter 2, Appendix 2-G "Injury } \\
\text { Prevention Program" }\end{array}$ & $\begin{array}{l}\text { DNT implements this requirement through } \\
\text { the DNT ISMS Implementation Plan. }\end{array}$ & $\begin{array}{l}\text { N Program implements these requirements through } \\
\text { referenced DNT processes }{ }^{*} \text {. }\end{array}$ & PAY \\
\hline 161 & (3) & $\begin{array}{l}\text { The HCD will provide each Directorate with injury statistics } \\
\text { and related information. }\end{array}$ & $\begin{array}{l}\text { - Chapter 2, Appendix 2-G "Injury } \\
\text { Prevention Program" }\end{array}$ & $\begin{array}{l}\text { DNT implements this requirement through } \\
\text { the DNT ISMS Implementation Plan. }\end{array}$ & $\begin{array}{l}\text { N Program implements these requirements through } \\
\text { referenced DNT processes }{ }^{\star} \text {. }\end{array}$ & N/A \\
\hline 162 & (4) & $\begin{array}{l}\text { Using resources such as the Lessons Learned program, } \\
\text { each Directorate is responsible for assessing whether } \\
\text { existing practices or conditions could materially contribute to } \\
\text { the organization's accident and injury rates. }\end{array}$ & $\begin{array}{l}\text { - Chapter 2, Appendix 2-G "Injury } \\
\text { Prevention Program" }\end{array}$ & $\begin{array}{l}\text { DNT implements this requirement through } \\
\text { the DNT ISMS Implementation Plan. }\end{array}$ & $\begin{array}{l}\text { N Program implements these requirements through } \\
\text { referenced DNT processes }{ }^{\star} \text {. }\end{array}$ & PAY \\
\hline 163 & (5) & $\begin{array}{l}\text { Each Directorate is responsible for developing programs to } \\
\text { address: }\end{array}$ & N/A & N/A & N/A & N/A \\
\hline 164 & (a) & $\begin{array}{l}\text { the specific injury/illness categories driving the } \\
\text { organization's lost and restricted work day numbers; }\end{array}$ & $\begin{array}{l}\text { - Chapter 2, Appendix 2-G "Injury } \\
\text { Prevention Program" }\end{array}$ & $\begin{array}{l}\text { DNT implements this requirement through } \\
\text { the DNT ISMS Implementation Plan. }\end{array}$ & $\begin{array}{l}\text { N Program implements these requirements through } \\
\text { referenced DNT processes }{ }^{\star} \text {. }\end{array}$ & PAY \\
\hline 165 & (b) & $\begin{array}{l}\text { other practices or conditions that could materially affect the } \\
\text { organization's accident and injury rates. }\end{array}$ & $\begin{array}{l}\text { - Chapter 2, Appendix 2-G "Injury } \\
\text { Prevention Program" }\end{array}$ & $\begin{array}{l}\text { DNT implements this requirement through } \\
\text { the DNT ISMS Implementation Plan. }\end{array}$ & $\begin{array}{l}\text { N Program implements these requirements through } \\
\text { referenced DNT processes }{ }^{\star} \text {. }\end{array}$ & PAY \\
\hline
\end{tabular}


N Program Integrated Safety Management Reqiurements Matrix 2/22/00

\begin{tabular}{|c|c|c|c|c|c|c|}
\hline & $\mathrm{A}$ & $\mathrm{B}$ & $\mathrm{C}$ & $\mathrm{D}$ & $E$ & $\mathrm{~F}$ \\
\hline 29 & Ref. & $\begin{array}{l}\text { Requirements from the } \\
\text { LLNL ISMS Description }\end{array}$ & $\begin{array}{l}\text { LLNL Implementing Procedures \& } \\
\text { Documents }\end{array}$ & $\begin{array}{c}\text { Directorate Implementing Procedures } \\
\text { \& Documents }\end{array}$ & N Program Implementation Requirements & Responsible Positions \\
\hline 166 & 6.5 .2 .2 & $\begin{array}{l}\text { ISMS Principles and Commitments Are Addressed in } \\
\text { Safety Documents }\end{array}$ & & & & \\
\hline 167 & (1) & $\begin{array}{l}\text { The ES\&H Manual and other Laboratory safety documents } \\
\text { are to address ISMS principles and commitments. }\end{array}$ & - Chapter 2, Section 2.1 & N/A & N/A & N/A \\
\hline & (2) & $\begin{array}{l}\text { The ES\&H Manual describes the approaches the } \\
\text { Laboratory uses to implement the ISMS. The ES\&H Manual } \\
\text { references and implements the WSS set as they relate to } \\
\text { specific work and hazards. }\end{array}$ & - Chapter 2, Sections 2.1 and 2.2.3 & N/A & N/A & N/A \\
\hline 169 & (3) & $\begin{array}{l}\text { The Directorate safety and safety-related documents (e.g., } \\
\text { IWSs, FSPs, OSPs, Self-assessment Plans, training plans, } \\
\text { etc.) are to be based on the ISMS principles and incorporate } \\
\text { the applicable requirements of the WSS set, all per the } \\
\text { provisions of the LLNL ISMS Description and the ES\&H } \\
\text { Manual. The IWS is a new and important addition to the } \\
\text { safety documents and needs to be included with an orderly } \\
\text { implementation of the ISM and WSS considerations in all of } \\
\text { the documents. The IWS is not required for the Superblock } \\
\text { activities as described in Section 7.3. of the LLNL ISMS } \\
\text { Description. }\end{array}$ & - Chapter 2, Section 2.3 & $\begin{array}{l}\text { DNT implements this requirement through } \\
\text { the DNT ISMS Implementation Plan. }\end{array}$ & $\begin{array}{l}\text { N Program implements these requirements through } \\
\text { referenced DNT processes*, relevant N Program } \\
\text { procedures, and the NPMP. }\end{array}$ & FMC, PMC \\
\hline 170 & $(4)$ & $\begin{array}{l}\text { For new work activities, the IWS is to be used starting } \\
\text { October } 1,1999 \text {. New FSPs, OSPs, and other safety- } \\
\text { related documents are to include the ISM and WSS } \\
\text { considerations also starting October } 1,1999 \text {. }\end{array}$ & - Chapter 2, Sections 2.3 and 2.1.2 & \begin{tabular}{|l|} 
DNT implements this requirement through \\
the DNT ISMS Implementation Plan. DNT \\
implemented the IWS for new work \\
activities starting October $1,1999$.
\end{tabular} & $\begin{array}{l}\text { N Program implements these requirements through } \\
\text { referenced DNT processes*, relevant N Program } \\
\text { procedures, and the NPMP. }\end{array}$ & FMC, PMC \\
\hline 171 & (5) & $\begin{array}{l}\text { For existing work activities with approved safety documents } \\
\text { (e.g. FSPs and OSPs), IWSs are to be prepared to ensure } \\
\text { incorporation of the ISMS requirements by the time of the } \\
\text { final verification. In the transition, these can use existing } \\
\text { approved safety documents in completing the IWS format } \\
\text { and obtaining the approval. Existing FSPs, OSPs, and } \\
\text { other safety-related documents are to be updated with the } \\
\text { ISM and WSS considerations by the next scheduled review } \\
\text { or the September } 2000 \text { milestone, whichever is earlier. }\end{array}$ & - Chapter 2, Section 2.3 & $\begin{array}{l}\text { DNT implements this requirement through } \\
\text { the DNT ISMS Implementation Plan. }\end{array}$ & $\begin{array}{l}\text { N Program implements these requirements through } \\
\text { referenced DNT processes*, relevant N Program } \\
\text { procedures, and the NPMP. }\end{array}$ & FMC, PMC \\
\hline$\frac{172}{173}$ & 6.5 .3 & $\begin{array}{l}\text { DOE Guiding Principle } 6 \text { - Hazard Controls Tailored to } \\
\text { Work Being Performed } \\
\text { Hazard controls are tailored to the project work. }\end{array}$ & & & & \\
\hline 174 & 6.5 .3 .1 & $\begin{array}{l}\text { Appropriate Sections of the ES\&H Manual Are Applied } \\
\text { in Tailoring Controls to Specific Work Activities }\end{array}$ & & & & \\
\hline 175 & (1) & $\begin{array}{l}\text { The individual supervising the work activity is responsible } \\
\text { for ensuring tailored controls are developed and } \\
\text { implemented for each hazard associated with the facility } \\
\text { and work activity consistent with the provisions of Section } 7 \\
\text { of the LLNL ISMS Description and the ES\&H Manual. }\end{array}$ & $\begin{array}{l}\text { - Chapter 1, Section 1.3.5; } \\
\text { - Chapter 2, Section 2.2.3 }\end{array}$ & $\begin{array}{l}\text { DNT implements these requirements } \\
\text { through the DNT ISMS Implementation } \\
\text { Plan, FSPs, OSPs, and IWSs. }\end{array}$ & $\begin{array}{l}\text { N Program implements these requirements through } \\
\text { referenced DNT processes*, relevant N Program } \\
\text { procedures, the NPMP, and the OSPs and FSPs. }\end{array}$ & RI \\
\hline \begin{tabular}{l|l|}
176 \\
178 \\
178
\end{tabular} & $\begin{array}{ll}6.6 \\
6.6 .1\end{array}$ & $\begin{array}{l}\text { Work Authorization and Execution } \\
\text { DOE Guiding Principle } 7 \text { - Operations Authorization } \\
\text { Operations are authorized before work begins. }\end{array}$ & & & & \\
\hline 179 & 6.6 .1 .1 & $\begin{array}{l}\text { Work Activities Are Appropriately Reviewed and } \\
\text { Authorized Before Starting }\end{array}$ & & & & \\
\hline 180 & (1) & $\begin{array}{l}\text { Work activities are to be reviewed and authorized before the } \\
\text { work begins consistent with the provisions of Section } 7 \text { of } \\
\text { the LLNL ISMS Description and the ES\&H Manual. }\end{array}$ & $\begin{array}{l}\text { - Chapter 1, Section 1.3.4; } \\
\text { - Chapter 2, Section 2.2.4 }\end{array}$ & $\begin{array}{l}\text { DNT implements these requirements } \\
\text { through the DNT ISMS Implementation } \\
\text { Plan, FSPs, OSPS, and IWSs. }\end{array}$ & $\begin{array}{l}\text { N Program implements these requirements through } \\
\text { referenced DNT processes*, relevant N Program } \\
\text { procedures, the NPMP, and the OSPs and FSPs. }\end{array}$ & FMC, PMC \\
\hline
\end{tabular}

* "Referenced DNT processes" are identified in the companion DNT column entitled "Directorate Implementing Procedures and Documents" 
N Program Integrated Safety Management Reqiurements Matrix 2/22/00

\begin{tabular}{|c|c|c|c|c|c|c|}
\hline & A & $B$ & $\mathrm{C}$ & $\mathrm{D}$ & $\mathrm{E}$ & $\mathrm{F}$ \\
\hline 29 & Ref. & $\begin{array}{l}\text { Requirements from the } \\
\text { LLNL ISMS Description }\end{array}$ & $\begin{array}{l}\text { LLNL Implementing Procedures \& } \\
\text { Documents }\end{array}$ & $\begin{array}{l}\text { Directorate Implementing Procedures } \\
\text { \& Documents }\end{array}$ & N Program Implementation Requirements & Responsible Positions \\
\hline 181 & (2) & $\begin{array}{l}\text { As part of this process, workers are to be provided an } \\
\text { opportunity to review and comment on the proposed } \\
\text { operating plans and/or procedures. }\end{array}$ & $\begin{array}{l}\text { - Chapter 1, Section 1.3.4; and } \\
\text { - Chapter 2, Section 2.2.4 }\end{array}$ & \begin{tabular}{|l} 
DNT implements these requirements \\
through the DNT ISMS Implementation \\
Plan, FSPs, OSPS, and IWSs.
\end{tabular} & $\begin{array}{l}\text { N Program implements these requirements through } \\
\text { referenced DNT processes*, relevant N Program } \\
\text { procedures, the NPMP, and the OSPS and FSPs. }\end{array}$ & |RI \\
\hline 182 & (3) & $\begin{array}{l}\text { The organization authorizing the work activity is responsible } \\
\text { for ensuring an appropriate prestart review is conducted to } \\
\text { validate satisfaction of the safety requirements. }\end{array}$ & $\begin{array}{l}\text { - Chapter 1, Section 1.3.4; } \\
\text { - Chapter 2, Section 2.2.4 }\end{array}$ & $\begin{array}{l}\text { DNT implements these requirements } \\
\text { through the DNT ISMS Implementation } \\
\text { Plan, FSPs, OSPs, and IWSs. }\end{array}$ & $\begin{array}{l}\text { N Program implements these requirements through } \\
\text { referenced DNT processes*, relevant N Program } \\
\text { procedures, the NPMP, and the OSPs and FSPs. }\end{array}$ & FMC, PMC \\
\hline 183 & $(4)$ & $\begin{array}{l}\text { The scope and rigor of the prestart review will vary based } \\
\text { upon the characteristics of the work activity. The } \\
\text { requirements of the prestart review process are defined in } \\
\text { the ES\&H Manual. }\end{array}$ & $\begin{array}{l}\text { - Chapter 1, Section 1.3.4; and } \\
\text { - Chapter 2, Section 2.2.4 and } \\
\text { Appendix 2-A }\end{array}$ & $\begin{array}{l}\text { DNT implements these requirements } \\
\text { through the DNT ISMS Implementation } \\
\text { Plan, FSPs, OSPs, and IWSs. }\end{array}$ & $\begin{array}{l}\text { N Program implements these requirements through } \\
\text { referenced DNT processes*, relevant N Program } \\
\text { procedures, the NPMP, and the OSPs and FSPs. }\end{array}$ & FMC, PMC \\
\hline 184 & 6.6.1.2 & Authorization Agreements & & & & \\
\hline 185 & (1) & 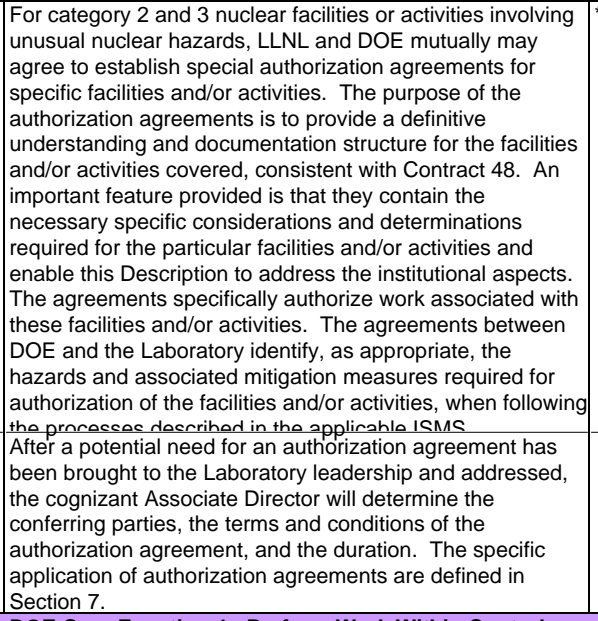 & ${ }^{*}$ Chapter 2, Appendix 2-C & $\begin{array}{l}\text { DNT has FAAs for the three Superblock } \\
\text { facilities (B331, B332, and B334). } \\
\text { Superblock has successfully completed } \\
\text { their ISMS Phase } 1 \text { and Phase } 2 \\
\text { Verification. }\end{array}$ & \begin{tabular}{|l|} 
LLNL, through N Program, implements this requirement \\
through the Activity Agreement process that has been \\
established by DOE/NV for NTS facilities, which would \\
include Category 2 and 3 nuclear facilities.
\end{tabular} & FMC \\
\hline 187 & 6.6.2 & DOE Core Function 4 - Perform Work Within Controls & & & & \\
\hline 188 & 6.6.2.1 & Work Is Appropriately Controlled & & & & \\
\hline 189 & (1) & $\begin{array}{l}\text { Each individual is responsible for adhering to the safety } \\
\text { controls established for the work activity and informing their } \\
\text { supervisors when controls are believed to be inadequate. }\end{array}$ & - Chapter 1, 1.3; & $\begin{array}{l}\text { DNT implements these requirements } \\
\text { through the DNT ISMS Implementation } \\
\text { Plan, FSPs, OSPs, and IWSs. }\end{array}$ & $\begin{array}{l}\text { N Program implements these requirements through } \\
\text { referenced DNT processes, relevant N Program } \\
\text { procedures, the NPMP, and the OSPs and FSPs. }\end{array}$ & IW \\
\hline 190 & (2) & $\begin{array}{l}\text { The supervisor of the work is responsible for ensuring that } \\
\text { the work is performed in accordance with the defined work } \\
\text { controls. }\end{array}$ & - Chapter 1, 1.3.5; & \begin{tabular}{|l} 
DNT implements these requirements \\
through the DNT ISMS Implementation \\
Plan, FSPS, OSPs, and IWSs.
\end{tabular} & $\begin{array}{l}\text { N Program implements these requirements through } \\
\text { referenced DNT processes, relevant N Program } \\
\text { procedures, the NPMP, and the OSPS and FSPs. }\end{array}$ & RI \\
\hline 191 & 6.6.2.2 & $\begin{array}{l}\text { Applicable Procedures Governing Documents Are } \\
\text { Followed }\end{array}$ & & & & \\
\hline 192 & (1) & \begin{tabular}{|l|} 
The individual supervising the work is responsible for \\
ensuring that each worker has immediate access to the \\
work activity's governing procedures and safety documents.
\end{tabular} & - Chapter 1, Section 1.3.5; & $\begin{array}{l}\text { DNT implements these requirements } \\
\text { through the DNT ISMS Implementation } \\
\text { Plan, FSPs, OSPs, and IWSs. }\end{array}$ & $\begin{array}{l}\text { N Program implements these requirements through } \\
\text { referenced DNT processes*, relevant N Program } \\
\text { procedures, the NPMP, and the OSPs and FSPs. }\end{array}$ & RI \\
\hline 193 & (2) & $\begin{array}{l}\text { Steps are taken by the individual supervising the work to } \\
\text { ensure that each worker on the activity is knowledgeable } \\
\text { concerning the governing procedures and work controls. }\end{array}$ & $\begin{array}{l}\text { - Chapter 1, Section 1.3.5; } \\
\text { - Chapter 2, Section 2.2.4 }\end{array}$ & $\begin{array}{l}\text { DNT implements these requirements } \\
\text { through the DNT ISMS Implementation } \\
\text { Plan, FSPS, OSPS, and IWSs. } \\
\end{array}$ & $\begin{array}{l}\text { N Program implements these requirements through } \\
\text { referenced DNT processes*, relevant N Program } \\
\text { procedures, the NPMP, and the OSPs and FSPs. }\end{array}$ & RI \\
\hline 194 & (3) & $\begin{array}{l}\text { All work is to be performed in conformance with applicable } \\
\text { procedures and governing documents. }\end{array}$ & $\begin{array}{l}\text { - Chapter 1, Section 1.3.5; } \\
\text { - Chapter 2, Section 2.2.4 }\end{array}$ & $\begin{array}{l}\text { DNT implements these requirements } \\
\text { through the DNT ISMS Implementation } \\
\text { Plan, FSPs, OSPS, and IWSs. }\end{array}$ & $\begin{array}{l}\text { N Program implements these requirements through } \\
\text { referenced DNT processes*, relevant N Program } \\
\text { procedures, the NPMP, and the OSPS and FSPS. }\end{array}$ & $\mathrm{RI}, \mathrm{IW}$ \\
\hline
\end{tabular}

* "Referenced DNT processes" are identified in the companion DNT column entitled "Directorate Implementing Procedures and Documents" 
N Program Integrated Safety Management Reqiurements Matrix 2/22/00

\begin{tabular}{|c|c|c|c|c|c|c|}
\hline & A & $\mathrm{B}$ & $\mathrm{C}$ & $\mathrm{D}$ & $E$ & $\mathrm{~F}$ \\
\hline 29 & Ref. & $\begin{array}{l}\text { Requirements from the } \\
\text { LLNL ISMS Description }\end{array}$ & $\begin{array}{l}\text { LLNL Implementing Procedures \& } \\
\text { Documents }\end{array}$ & $\begin{array}{l}\text { Directorate Implementing Procedures } \\
\text { \& Documents }\end{array}$ & N Program Implementation Requirements & Responsible Positions \\
\hline 196 & $\begin{array}{l}6.7 \\
6.7 .1\end{array}$ & $\begin{array}{l}\text { Performance Monitoring and Feedback } \\
\text { DOE Core Function } 5 \text { - Provide Feedback and } \\
\text { Continuous Improvement }\end{array}$ & & & & \\
\hline 197 & 6.7.1.1 & Work Activities Are Monitored & & & & \\
\hline 198 & $(1)$ & $\begin{array}{l}\text { The individual supervising the work is responsible for } \\
\text { monitoring the work activity to ensure that the governing } \\
\text { procedures and safety documents are being followed. }\end{array}$ & $\begin{array}{l}\text { - Chapter 1, Sections 1.3.5; } \\
\text { - Chapter 2, Section 2.2.5 }\end{array}$ & $\begin{array}{l}\text { DNT implements these requirements } \\
\text { through the DNT ISMS Implementation } \\
\text { Plan, FSPs, OSPs, and IWSs. }\end{array}$ & $\begin{array}{l}\text { N Program implements these requirements through } \\
\text { referenced DNT processes*, relevant N Program } \\
\text { procedures, the NPMP, and the OSPS and FSPs. }\end{array}$ & $\mid \mathrm{RI}$ \\
\hline 199 & (2) & $\begin{array}{l}\text { In the event it is determined that the Work Activity's limits } \\
\text { and/or controls are not being followed, the affected work is } \\
\text { to be reevaluated by the organization authorizing the work } \\
\text { activity and suspended, if appropriate, until remedial actions } \\
\text { are taken. }\end{array}$ & $\begin{array}{l}\text { - Chapter 1, Sections 1.3, and 1.3.5; } \\
\text { - Chapter 2, Section 2.2.5 }\end{array}$ & $\begin{array}{l}\text { DNT implements these requirements } \\
\text { through the DNT ISMS Implementation } \\
\text { Plan, FSPs, OSPs and IWSs. }\end{array}$ & $\begin{array}{l}\text { N Program implements these requirements through } \\
\text { referenced DNT processes*, relevant N Program } \\
\text { procedures, the NPMP, and the OSPS and FSPs. }\end{array}$ & PAY, FMC, PMC \\
\hline 200 & (3) & $\begin{array}{l}\text { In the event it is determined that the approved Work Activity } \\
\text { Authorization or the Facility Operation Authorization per the } \\
\text { provisions of Section } 7 \text { of the LLNL ISMS Description and } \\
\text { the ES\&H Manual is exceeded, the affected work and/or } \\
\text { facility is to be placed in a safe condition and further work } \\
\text { suspended until appropriate remedial actions are taken. }\end{array}$ & $\begin{array}{l}\text { - Chapter 1, Section 1.3.5; } \\
\text { - Chapter 2, Section 2.2.5 }\end{array}$ & $\begin{array}{l}\text { DNT implements these requirements } \\
\text { through the DNT ISMS Implementation } \\
\text { Plan, FSPs, OSPs and IWSs. }\end{array}$ & $\begin{array}{l}\text { N Program implements these requirements through } \\
\text { referenced DNT processes*, relevant N Program } \\
\text { procedures, the NPMP, and the OSPs and FSPs. }\end{array}$ & FMC, PMC, RI, IW \\
\hline 201 & (4) & $\begin{array}{l}\text { Each worker is responsible for bringing to the attention of } \\
\text { their immediate supervisor problems with the applicable } \\
\text { operating limits and/or controls and opportunities for } \\
\text { improvement associated with the work or governing } \\
\text { procedure(s). The supervisor is responsible for the } \\
\text { evaluation and appropriate action. }\end{array}$ & $\begin{array}{l}\text { - Chapter 1, Sections } 1.3 \text { and 1.3.1; } \\
\text { - Chapter 2, Section 2.2.5 }\end{array}$ & $\begin{array}{l}\text { DNT implements these requirements } \\
\text { through the DNT ISMS Implementation } \\
\text { Plan, FSPs, OSPs and IWSs. This } \\
\text { requirement is also incorporated into DNT } \\
\text { Directorate ES\&H Policy and DNT ISMS } \\
\text { Training. }\end{array}$ & $\begin{array}{l}\text { N Program implements these requirements through } \\
\text { referenced DNT processes*, relevant N Program } \\
\text { procedures, the NPMP, and the OSPs and FSPs. }\end{array}$ & $\mathrm{RI}, \mathrm{IW}$ \\
\hline 202 & (5) & $\begin{array}{l}\text { Each worker is empowered to stop work if there is an } \\
\text { unsafe or unapproved condition. Prompt notification of the } \\
\text { immediate supervisor is required. Resumption of work will } \\
\text { not proceed until after the condition has been evaluated and } \\
\text { the appropriate remedial actions have been taken. }\end{array}$ & $\begin{array}{l}\text { - Chapter 1, Sections } 1.3 \text { and 1.7; } \\
\text { - Chapter 2, Section 2.2.5 }\end{array}$ & $\begin{array}{l}\text { DNT implements these requirements } \\
\text { through the DNT ISMS Implementation } \\
\text { Plan, FSPs, OSPs and IWSs. This } \\
\text { requirement is also incorporated into DNT } \\
\text { Directorate ES\&H Policy and DNT ISMS } \\
\text { Training. }\end{array}$ & $\begin{array}{l}\text { N Program implements these requirements through } \\
\text { referenced DNT processes*, relevant N Program } \\
\text { procedures, the NPMP, and the OSPS and FSPs. }\end{array}$ & FMC, PMC, RI, IW \\
\hline 203 & 6.7 .1 .2 & Safety Self-Assessment Programs Are Defined & & & & \\
\hline 204 & (1) & $\begin{array}{l}\text { The purpose of the Laboratory's safety self-assessment } \\
\text { program is to ensure a proactive approach to safety and to } \\
\text { improve safety performance. The specific objectives of } \\
\text { LLNL's safety self-assessment program are to ensure: }\end{array}$ & $\mathrm{N} / \mathrm{A}$ & N/A & N/A & $\mathrm{N} / \mathrm{A}$ \\
\hline 205 & (a) & $\begin{array}{l}\text { Laboratory operations comply with applicable safety policies } \\
\text { and procedures; }\end{array}$ & - Supplement 2.04 & \begin{tabular}{|l|} 
DNT implements these requirements \\
through the DNT ISMS Implementation \\
Plan and the DNT Self-Assessment Plan.
\end{tabular} & $\begin{array}{l}\text { N Program implements these requirements through } \\
\text { referenced DNT processes*, relevant N Program } \\
\text { procedures, the NPMP, and the OSPS and FSPS. }\end{array}$ & PAY, FMC, PMC \\
\hline 206 & (b) & $\begin{array}{l}\text { safety-related requirements are integrated into all levels of } \\
\text { facility, management, and operational activities; }\end{array}$ & - Supplement 2.04 & $\begin{array}{l}\text { DNT implements these requirements } \\
\text { through the DNT ISMS Implementation } \\
\text { Plan and the DNT Self-Assessment Plan. }\end{array}$ & $\begin{array}{l}\text { N Program implements these requirements through } \\
\text { referenced DNT processes } \\
\text { procedures, the relevant N Program } \\
\text { prop, and the OSPS and FSPs. }\end{array}$ & PAY, FMC, PMC \\
\hline 207 & (c) & $\begin{array}{l}\text { safety-related deficiencies are identified, analyzed, and } \\
\text { managed in order to minimize their occurrence or } \\
\text { recurrence. }\end{array}$ & - Supplement 2.04 & $\begin{array}{l}\text { DNT implements these requirements } \\
\text { through the DNT ISMS Implementation } \\
\text { Plan and the DNT Self-Assessment Plan. }\end{array}$ & $\begin{array}{l}\text { N Program implements these requirements through } \\
\text { referenced DNT processes } \\
\text { procedures, the revant N Program } \\
\text { prMP, and the OSPS and FSPs. }\end{array}$ & FMC, PMC \\
\hline 208 & (2) & $\begin{array}{l}\text { Each directorate is to develop and operate a safety self- } \\
\text { assessment program consistent with the requirements } \\
\text { specified in the ES\&H Manual. }\end{array}$ & - Supplement 2.04 & \begin{tabular}{|l|} 
DNT implements these requirements \\
through the DNT ISMS Implementation \\
Plan and the DNT Self-Assessment Plan.
\end{tabular} & $\begin{array}{l}\text { N Program implements these requirements through } \\
\text { referenced DNT processes } \\
\text { procedures, the revant N Program } \\
\text { pPMP, and the OSPS and FSPs. }\end{array}$ & PAY, FMC, PMC \\
\hline 209 & (3) & $\begin{array}{l}\text { As an integral part of the safety self-assessment process, } \\
\text { each Directorate is to perform an annual evaluation of its } \\
\text { implementation of the LLNL ISMS. The evaluation is to } \\
\text { include a review of the Directorate Implementation Plan and } \\
\text { any succeeding documentation to ensure it remains } \\
\text { workable, current, and in conformance with the LLNL ISMS } \\
\text { Description. }\end{array}$ & $\begin{array}{l}\text { - Supplement } 2.04 \\
\text { - Chapter 1, Section 1.3.3 }\end{array}$ & \begin{tabular}{|l|} 
DNT implements these requirements \\
through the DNT ISMS Implementation \\
Plan and the DNT Self-Assessment Plan.
\end{tabular} & $\begin{array}{l}\text { N Program implements these requirements through } \\
\text { referenced DNT processes*, relevant N Program } \\
\text { procedures, the NPMP, and the OSPS and FSPs. }\end{array}$ & PAY, FMC, PMC \\
\hline
\end{tabular}


N Program Integrated Safety Management Reqiurements Matrix 2/22/00

\begin{tabular}{|c|c|c|c|c|c|c|}
\hline & $\mathrm{A}$ & $\mathrm{B}$ & $\mathrm{C}$ & $\mathrm{D}$ & $\mathrm{E}$ & $\mathrm{F}$ \\
\hline 29 & Ref. & $\begin{array}{l}\text { Requirements from the } \\
\text { LLNL ISMS Description }\end{array}$ & $\begin{array}{l}\text { LLNL Implementing Procedures \& } \\
\text { Documents }\end{array}$ & $\begin{array}{c}\text { Directorate Implementing Procedures } \\
\text { \& Documents }\end{array}$ & N Program Implementation Requirements & Responsible Positions \\
\hline 210 & 6.7.1.3 & $\begin{array}{l}\text { Processes Are in Place to Measure and Reinforce } \\
\text { Safety Requirements and Expectations }\end{array}$ & & & & \\
\hline 211 & (1) & $\begin{array}{l}\text { Establishing safety performance measures is a collective } \\
\text { effort by the Laboratory, University of California, and } \\
\text { DOE/OAK. The measures to gauge safety system } \\
\text { effectiveness are determined through negotiations by } \\
\text { multiple teams and managed through the Appendix F } \\
\text { processes. }\end{array}$ & - Chapter 1, Section 1.3.6 & Institutional Process & $\begin{array}{l}\text { N Program implements these requirements through } \\
\text { referenced DNT processes }{ }^{*} \text {. }\end{array}$ & N/A \\
\hline 212 & (2) & $\begin{array}{l}\text { The ES\&H performance measures process is managed at } \\
\text { an institutional level by the ES\&H Functional Manager. The } \\
\text { ES\&H Working Group plays a key role in facilitating the } \\
\text { ES\&H performance measures process. }\end{array}$ & - Chapter 1, Section 1.3.6 & Institutional Process & $\begin{array}{l}\text { N Program implements these requirements through } \\
\text { referenced DNT processes*. }\end{array}$ & $\mathrm{N} / \mathrm{A}$ \\
\hline 213 & (3) & $\begin{array}{l}\text { Each Directorate is responsible for providing required } \\
\text { performance measure information. In turn, summary } \\
\text { performance measure information is provided back to each } \\
\text { Directorate. }\end{array}$ & - Chapter 1, Section 1.3.6 & $\begin{array}{l}\text { DNT implements these requirements } \\
\text { through the DNT ISMS Implementation } \\
\text { Plan. }\end{array}$ & $\begin{array}{l}\text { N Program implements these requirements through } \\
\text { referenced DNT processes*. }\end{array}$ & PAY, FMC, PMC \\
\hline 214 & (4) & $\begin{array}{l}\text { Performance measure information is accessible to all } \\
\text { employees. }\end{array}$ & - Chapter 2, Section 2.2.5 & Institutional Process & $\begin{array}{l}\text { N Program implements these requirements through } \\
\text { referenced DNT processes }{ }^{*} \text {. }\end{array}$ & N/A \\
\hline 215 & (5) & $\begin{array}{l}\text { Each Directorate is responsible for having appropriate } \\
\text { metrics to evaluate its safety performance. }\end{array}$ & - Chapter 2, Section 2.2.5 & $\begin{array}{l}\text { Directorate metrics are evaluated in the } \\
\text { Annual ES\&H Self-Assessment Report } \\
\text { from the AD. }\end{array}$ & $\begin{array}{l}\text { N Program implements these requirements through } \\
\text { referenced DNT processes }{ }^{*} \text {. }\end{array}$ & PAY \\
\hline 216 & 6.7.1.4 & $\begin{array}{l}\text { Processes Are Defined for Analyzing Problems, } \\
\text { Identifying Root Causes, and Ensuring Corrective } \\
\text { Actions Are Taken }\end{array}$ & & & & \\
\hline 217 & (1) & $\begin{array}{l}\text { Each Directorate is responsible for analyzing, tracking, } \\
\text { trending, and correcting safety-related problems and } \\
\text { deficiencies associated with its operations and facilities. }\end{array}$ & $\begin{array}{l}\text { - Chapter 1, Section 1.3.3; } \\
\text { - Chapter 2, 2.2.5 }\end{array}$ & \begin{tabular}{|l|} 
DNT implements these requirements \\
through the DNT ISMS Implementation \\
Plan and the DNT Self-Assessment Plan.
\end{tabular} & $\begin{array}{l}\text { N Program implements these requirements through } \\
\text { referenced DNT processes } \\
\text { procedures, relevant N } \mathrm{N} \text { Program } \\
\text { pre OSPS and FSPS. }\end{array}$ & PAY, FMC, PMC \\
\hline 218 & (2) & $\begin{array}{l}\text { Each Directorate is to record and track safety-related } \\
\text { deficiencies consistent with the provisions and thresholds } \\
\text { specified in the ES\&H Manual. Each Directorate is } \\
\text { responsible for correcting deficiencies from requirements, } \\
\text { as described in the ES\&H Manual. }\end{array}$ & $\begin{array}{l}\text { - Chapter 1, Section 1.3.3; } \\
\text { - Chapter 2, Section 2.2.5; and } \\
\text { - Supplement 2.03 }\end{array}$ & \begin{tabular}{|l|} 
DNT implements these requirements \\
through the DNT ISMS Implementation \\
Plan and the DNT Self-Assessment Plan.
\end{tabular} & $\begin{array}{l}\text { N Program implements these requirements through } \\
\text { referenced DNT processes } \\
\text { procedures, relevant N Program the OSPs and FSPs. }\end{array}$ & PAY, FMC, PMC \\
\hline 219 & (3) & $\begin{array}{l}\text { Each Directorate is responsible for reporting, analyzing, } \\
\text { tracking, and correcting safety-related occurrences } \\
\text { consistent with the Laboratory's implementing procedure for } \\
\text { occurrence reporting. }\end{array}$ & $\begin{array}{l}\text { - Chapter 1, Section 1.3.3; } \\
\text { - Chapter 4, Section 4.5.1; } \\
\text { - LLNL Implementing Procedure for } \\
\text { Occurrence Reporting. }\end{array}$ & $\begin{array}{l}\text { DNT implements these requirements } \\
\text { through the DNT ISMS Implementation } \\
\text { Plan and the DNT ORP. }\end{array}$ & $\begin{array}{l}\text { N Program implements these requirements through } \\
\text { referenced DNT processes } \\
\text { procedures, relevant N Program } \\
\text { pPMP, and the OSPs and FSPs. }\end{array}$ & PAY, FMC, PMC \\
\hline 220 & (4) & $\begin{array}{l}\text { Serious safety-related incidents are to be formally reviewed } \\
\text { and addressed consistent with the provisions of the ES\&H } \\
\text { Manual. }\end{array}$ & $\begin{array}{l}\text { - Chapter 1, Section 1.3.3; } \\
\text { - Chapter 4, Section 4.4.4; } \\
\text { - Supplement 4.08; } \\
\text { - LLNL Implementing Procedure for } \\
\text { Occurrence Reporting. }\end{array}$ & $\begin{array}{l}\text { DNT implements these requirements } \\
\text { through the DNT ISMS Implementation } \\
\text { Plan. }\end{array}$ & $\begin{array}{l}\text { N Program implements these requirements through } \\
\text { referenced DNT processes } \\
\text { procedures, relevant N Program } \\
\text { pre OSPs and FSPs. }\end{array}$ & FMC, PMC \\
\hline 221 & $(5)$ & $\begin{array}{l}\text { Each Directorate is to use medical surveillance } \\
\text { examinations as appropriate to assess impacts of work on } \\
\text { employee health. }\end{array}$ & $\begin{array}{l}\text { - Chapter 1, Section 1.3.4 } \\
\text { - Chapter 5, Section 5.2.3 }\end{array}$ & $\begin{array}{l}\text { DNT implements these requirements } \\
\text { directly from the ES\&H Manual and in } \\
\text { FSPS. }\end{array}$ & $\begin{array}{l}\text { N Program implements these requirements through } \\
\text { referenced DNT processes*, and relevant N Program } \\
\text { procedures. }\end{array}$ & PAY \\
\hline 222 & $(6)$ & $\begin{array}{l}\text { Root cause analyses are to be performed for occurrences, } \\
\text { formal incident analyses, and other safety-related issues } \\
\text { deemed appropriate by the Directorate. }\end{array}$ & $\begin{array}{l}\text { - Chapter 1, Section 1.3.3; } \\
\text { - Chapter 4, Section 4.4.3; } \\
\text { - Supplement 4.08; } \\
\text { - LLNL Implementing Procedure for } \\
\text { Occurrence Reporting. }\end{array}$ & $\begin{array}{l}\text { DNT implements these requirements } \\
\text { through the DNT ISMS Implementation } \\
\text { Plan. }\end{array}$ & $\begin{array}{l}\text { N Program implements these requirements through } \\
\text { referenced DNT processes }{ }^{*} \text {, relevant N Program } \\
\text { procedures, and the OSPs and FSPs. }\end{array}$ & FMC, PMC \\
\hline 223 & 6.7.1.5 & $\begin{array}{l}\text { An Annual Independent Assessment of LLNL's ISMS Is } \\
\text { Conducted }\end{array}$ & & & & \\
\hline 224 & (1) & $\begin{array}{l}\text { The ARO is responsible for conducting an annual } \\
\text { independent assessment of the LLNL ISMS. }\end{array}$ & $\begin{array}{l}\cdot \text { Chapter } 1 \text {, Section 1.3.9, ARO Sub- } \\
\text { section }\end{array}$ & N/A & N/A & N/A \\
\hline
\end{tabular}


N Program Integrated Safety Management Reqiurements Matrix 2/22/00

\begin{tabular}{|c|c|c|c|c|c|c|}
\hline & A & $\mathrm{B}$ & $\mathrm{C}$ & $\mathrm{D}$ & $E$ & $\mathrm{~F}$ \\
\hline 29 & Ref. & $\begin{array}{l}\text { Requirements from the } \\
\text { LLNL ISMS Description }\end{array}$ & $\begin{array}{l}\text { LLNL Implementing Procedures \& } \\
\text { Documents }\end{array}$ & $\begin{array}{c}\text { Directorate Implementing Procedures } \\
\text { \& Documents }\end{array}$ & N Program Implementation Requirements & Responsible Positions \\
\hline 225 & (2) & $\begin{array}{l}\text { The ARO is to periodically assess continued conformance } \\
\text { of each Directorate Implementation Plan and any } \\
\text { succeeding documentation with this Description. }\end{array}$ & $\begin{array}{l}\cdot \text { Chapter } 1 \text {, Section 1.3.9, ARO Sub- } \\
\text { section }\end{array}$ & $\mathrm{N} / \mathrm{A}$ & N/A & N/A \\
\hline 226 & (3) & $\begin{array}{l}\text { The ARO assessment is to include an evaluation of each } \\
\text { Directorate's implementation of the LLNL ISMS in } \\
\text { accordance with the commitments and plans made in its } \\
\text { Directorate Implementation Plan and any succeeding } \\
\text { documentation. }\end{array}$ & $\begin{array}{l}\text { - Chapter 1, Section 1.3.9, ARO Sub- } \\
\text { section }\end{array}$ & N/A & N/A & N/A \\
\hline 227 & 6.7.1.6 & Lessons Learned Are Effectively Transmitted & & & & \\
\hline 228 & (1) & $\begin{array}{l}\text { The Laboratory's Lessons Learned Coordinator gathers } \\
\text { information regarding potential Lessons Learned from } \\
\text { internal and external sources based on experiences } \\
\text { considered relevant to Laboratory operations. Potential } \\
\text { Lessons Learned are reviewed with several ES\&H } \\
\text { organizations within the Laboratory, including members of } \\
\text { the ES\&H Working Group, before being distributed. }\end{array}$ & $\begin{array}{l}\text { - Chapter 2, Appendix 2-D, "Lessons } \\
\text { Learned Program" }\end{array}$ & $\begin{array}{l}\text { Institutional Process. DNT AM supports } \\
\text { this function. }\end{array}$ & $\begin{array}{l}\text { N Program implements these requirements through } \\
\text { referenced DNT processes*. }\end{array}$ & N/A \\
\hline 229 & (2) & $\begin{array}{l}\text { Lessons Learned are to be shared to enhance operational } \\
\text { safety and facilitate cost effectiveness. Individuals are to be } \\
\text { encouraged to submit Lessons Learned. }\end{array}$ & $\begin{array}{l}\text { - Chapter 1, Sections 1.3.3 and 1.3.5; } \\
\text { - Chapter 2, Appendix 2-D, "Lessons } \\
\text { Learned Program" }\end{array}$ & $\begin{array}{l}\text { DNT implements this requirement through } \\
\text { the DNT ISMS Implementation Plan. }\end{array}$ & $\begin{array}{l}\text { N Program implements these requirements through } \\
\text { referenced DNT processes } \\
\text { procedures, the NPMP, and the OSPS N Program } \\
\text { pros FPS. }\end{array}$ & PAY, FMC, PMC, RI \\
\hline 230 & (3) & $\begin{array}{l}\text { Lessons Learned are to be prepared and distributed } \\
\text { whenever there is an opportunity to share a valuable new } \\
\text { work practice or warn others of an adverse practice, } \\
\text { experience, or product. }\end{array}$ & $\begin{array}{l}\text { - Chapter 1, Section 1.3.5; } \\
\text { - Chapter 2, Appendix 2-D, "Lessons } \\
\text { Learned Program" }\end{array}$ & $\begin{array}{l}\text { DNT implements this requirement through } \\
\text { the DNT ISMS Implementation Plan. }\end{array}$ & $\begin{array}{l}\text { N Program implements these requirements through } \\
\text { referenced DNT processes } \\
\text { procedures, relevant N Program } \\
\text { pPMP, and the OSPs and FSPs. }\end{array}$ & PAY, FMC, PMC \\
\hline 231 & (4) & $\begin{array}{l}\text { Lessons Learned are transmitted by the Lessons Learned } \\
\text { Coordinator to individuals identified by each Directorate's } \\
\text { Assurance Manager. In addition, each Assurance Manager } \\
\text { is responsible for ensuring transmission of Lessons Learned } \\
\text { to other appropriate personnel. }\end{array}$ & $\begin{array}{l}\text { - Chapter 2, Appendix 2-D, "Lessons } \\
\text { Learned Program" }\end{array}$ & DNT AM performs this function. & $\begin{array}{l}\text { N Program implements these requirements through } \\
\text { referenced DNT processes }{ }^{*} \text {. }\end{array}$ & N/A \\
\hline 232 & $(5)$ & Lessons Learned will be posted on the "LLNL only" website. & $\begin{array}{l}\text { - Chapter 2, Appendix 2-D, "Lessons } \\
\text { Learned Program" }\end{array}$ & $\begin{array}{l}\text { N/A. This is a function of the LLNL } \\
\text { Lessons Learned Coordinator. }\end{array}$ & N/A & N/A \\
\hline 233 & $(6)$ & $\begin{array}{l}\text { The organization authorizing work is responsible for } \\
\text { ensuring that applicable Lessons Learned maintained on } \\
\text { the "LLNL only" website are considered during the process } \\
\text { of authorizing work. }\end{array}$ & - Chapter 1, Section 1.3.4 & $\begin{array}{l}\text { DNT implements these requirements } \\
\text { directly from the ES\&H Manual. }\end{array}$ & $\begin{array}{l}\text { N Program implements these requirements through } \\
\text { referenced DNT processes } \\
\text { procedures, relevant N Program } \\
\text { phe NPMP. }\end{array}$ & FMC, PMC \\
\hline 234 & $(7)$ & $\begin{array}{l}\text { A review of Lessons Learned maintained on the "LLNL only" } \\
\text { website is incorporated into each Directorate's self- } \\
\text { assessment program to ensure continued utilization of } \\
\text { relevant Lessons Learned. }\end{array}$ & - Chapter 1, Section 1.3.4 & $\begin{array}{l}\text { DNT implements these requirements } \\
\text { through the DNT ISMS Implementation } \\
\text { Plan. }\end{array}$ & $\begin{array}{l}\text { N Program implements these requirements through } \\
\text { referenced DNT processes*, and relevant N Program } \\
\text { procedures. }\end{array}$ & PAY, FMC, PMC \\
\hline 235 & $(8)$ & $\begin{array}{l}\text { Lessons Learned considered of importance to DOE } \\
\text { operations outside of LLNL are shared with the greater DOE } \\
\text { community through the DOE listserver program and through } \\
\text { DOE's website for Lessons Learned. }\end{array}$ & $\begin{array}{l}\text { - Chapter 2, Appendix 2-D, "Lessons } \\
\text { Learned Program" }\end{array}$ & $\begin{array}{l}\text { N/A. This is a function of the LLNL } \\
\text { Lessons Learned Coordinator. }\end{array}$ & N/A & N/A \\
\hline 236 & 6.7.1.7 & $\begin{array}{l}\text { Improvements are to be Incorporated into the } \\
\text { Organization's ISMS }\end{array}$ & & & & \\
\hline 237 & (1) & $\begin{array}{l}\text { Based on the information derived from the various } \\
\text { performance monitoring and feedback processes, } \\
\text { appropriate improvements are to be incorporated into the } \\
\text { Directorate's implementation and continuation of the LLNL } \\
\text { ISMS or the ES\&H Manual, as appropriate. }\end{array}$ & - Chapter 2, Section 2.2.5 & \begin{tabular}{|l|} 
DNT implements these requirements \\
through the DNT ISMS Implementation \\
Plan and the DNT Self-Assessment Plan.
\end{tabular} & $\begin{array}{l}\text { N Program implements these requirements through } \\
\text { referenced DNT processes*, and relevant N Program } \\
\text { procedures. }\end{array}$ & PAY, FMC, PMC \\
\hline 238 & 6.8 & Conclusion & & & & \\
\hline 239 & $(1)$ & $\begin{array}{l}\text { Unique issues and special cases not articulated in the set of } \\
\text { core requirements in this Section are to be addressed by } \\
\text { the identified management chain and taken to the } \\
\text { responsible AD for resolution and then, as necessary, to the } \\
\text { DDO. }\end{array}$ & - Chapter 1, Section 1.3.1 & $\begin{array}{l}\text { Unique issues associated with standards } \\
\text { governing DNT work are incorporated into } \\
\text { the DNT ISMS Implementation Plan. }\end{array}$ & $\begin{array}{l}\text { N Program implements these requirements through } \\
\text { referenced DNT processes* , and relevant N Program } \\
\text { procedures. }\end{array}$ & PAY, FMC, PMC \\
\hline
\end{tabular}

